\title{
Türk-İslam Kubbelerinde Çarkıfelek Formları
}

\section{Wheel of Fortune Forms in Turkish-Islamic Domes}

\author{
Alper Altın ${ }^{1}$ (D)
}

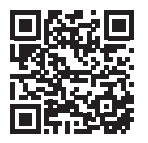

${ }^{1}$ (Doç. Dr.), Nevşehir Hacı Bektaș Veli Üniversitesi, FenEdebiyat Fakültesi, Sanat Tarihi Bölümü,

Nevşehir, Türkiye

ORCID: A.A. 0000-0002-9295-3428

Sorumlu yazar/Corresponding author: Alper Altın,

Nevşehir Hacı Bektaş Veli Üniversitesi, Fen-Edebiyat Fakültesi, Sanat Tarihi Bölümü, Nevşehir, Türkiye E-posta: alperaltin@nevsehir.edu.tr

Başvuru/Submitted: 11.12.2020

Revizyon Talebi/Revision Requested: 24.03.2021 Son Revizyon/Last Revision Received: 18.05.2021 Kabul/Accepted: 29.05 .2021

Online Yayın/Published Online: 30.06.2021

Atıf/Citation: Altin, Alper. "Türk-Islam Kubbelerinde Çarkıfelek Formları"'. Sanat Tarihi Yılliğı - Journal of Art History 30 (2021), 29-80.

https://doi.org/10.26650/sty.2021.839119

\section{öz}

Kadim bir geçmişi olan çarkıfelek (fırıldak) sembolü dünyanın ve evrenin devinimini, kaderi, sonsuzluğu ve ölümsüzlüğü simgelemektedir. El sanatları ve mimari plastik süslemelerde görülen çarkıfelek motifi, kubbelerde de kullanılmıştır. Bu çalışmada Türk-İslam yapılarında karşımıza çıkan çarkıfelek süslemeli kubbeler ele alınmıştır. Çeşitli coğrafyalarda bulunan otuz dokuz adet çarkıfelek süslemeli kubbe, sanat tarihi açısından değerlendirilmiştir. Bizim saptayamadığımız veya günümüze gelememişörneklerin olabileceği düşünülürse bu sayının daha da fazla olduğu belirtilebilir. Örneklerden on yedisi İran'da, ikisi Mısır'da, biri Özbekistan'da, biri Bulgaristan'da geriye kalan kısmı ise Türkiye sınırları içerisinde yer almaktadır. Bunlardan en erken tarihlisi 11-12. yüzyıla kadar gitmektedir. Tespit ettiğimiz ilk örnek İran coğrafyasında yer almaktadır. Çarkıfelek süslemeli kubbe Türklerle birlikte Mısır, Türkiye ve Balkan coğrafyasına taşınmıştır. Konu kapsamındaki çarkıfelek süslemeli kubbeler, yazılı ve görsel kaynaklar taranarak tespit edilmiş ve belirlenen örneklerin çizimleri fotoğraflar üzerinden yapılmıştır. Çarkıfelek formlu kubbeler kronolojik olarak katalog halinde tanıtılmıştır. Çarkıfelek sembolünün mekanı örten yarım küre biçimli üst örtülerde kullanılmasının ikonografik anlamları irdelenmiştir. Türk-İslam sanatı içerisindeki yeri ve önemi üzerinde durularak genel bir değerlendirilmeye gidilmiştir. Çarkıfelek süslemeli kubbelerin başka mimarilerde görülen örneklerine değinilmiş, sadece geçmişteki yapılarda değil yakın dönemdeki yapılarda da kullanıldığı saptanmıştır.

Anahtar kelimeler: Türk-İslam Mimarisi, Türk-İslam Sanatı, Süsleme, Çarkıfelek, Kubbe

\section{ABSTRACT}

The symbol of the wheel of fortune (pinwheel) has an ancient past and symbolizes the movement of the world and the universe, destiny, eternity, and immortality. The wheel of fortune motif, which is seen in handicrafts and architectural plastic decoration, has also been used in domes. This study discusses the domes decorated with the wheel of fortune that we encounter in Turkish-Islamic structures. Thirty-nine domes which are decorated with the wheel of fortune in various locations were evaluated in terms of art history. Considering that some examples have not survived or we could not trace them, we can safely say that this number is probably even greater. Seventeen of the examples are in Iran, two in Egypt, one in Uzbekistan, and one in Bulgaria, whereas the remaining examples are located within the borders of Turkey. The earliest of these dates back to the 11 th-12th centuries. The first example we identified is located in 
Iran. Domes with a pinwheel ornament together had brought to Egypt, Turkey, and the Balkans by Turks. Domes decorated with a wheel of fortune within the scope of the subject were determined by scanning written and visual resources, and drawings of the identified examples were made from photographs. The wheel of fortune decorated domes were cataloged chronologically. Some special meanings, such as iconographic meanings of the use of the wheel of fortune symbol on the hemispherical top covering the space, were discussed. A general evaluation has been made by emphasizing the symbol's place and importance in Turkish-Islamic art. Examples of domes decorated with the wheel of fortune, seen in other architectures, are presented. It was noted that the symbol is used not only in historic buildings but also in recent buildings.

Keywords: Turkish-Islamic Architecture, Turkish-Islamic Art, Ornament, Wheel of Fortune, Dome

\section{EXTENDED ABSTRACT}

Throughout history, people have attributed symbolic meanings by symbolizing natural objects such as the sun, mountains, wind, and fire via abstract forms such as a square, circle, triangle, or objects made by human hand. Symbols have demonstrated variety in every society, culture, and language. For example, while the number four does not have a negative meaning in other societies, Far Eastern societies have avoided this word since the number four (si) and the word death are homophonic. In addition, there are many universal symbols. The wheel is the general name of the circular parts that rotate around an axis with more than two arms, which have many types. The most primitive type of wheel is a four-armed wheel called a swastika. It has been suggested that the origin of the swastika given in a cyclic structure within the square goes back to the Mayans and Sumerians (4000s BC.). It is also sacred according to South Asian Hinduism, Buddhism, and Jainism. One of the oldest symbols seen in Anatolia, the wheel of fortune symbolizes the movement of the world and the universe, the circle of destiny, and fate. However, the wheel of fortune is a reflection of metaphysical philosophy. The wheel of fortune motif is frequently seen in mosques, madrasahs, caravanserais, tombs, and tombstones among Turkish-Islamic artifacts in Anatolia. This motif is included in various handicraft products as well. The wheel of fortune motif has often been used on embroidered medallions incorporated into architecture. In addition, it has been associated with the sky by covering the interior of an architectural element such as a dome.

Domes, one of the indispensable architectural elements of Islamic buildings, were sometimes left simple and unadorned by artists due to their elegant forms. At the same time both the inside and outside of these curved surfaces were decorated with various motifs. The domes, which are decorated with different materials and techniques using stone, brick, stucco, tile, and hand-drawn motifs draw the viewers' attention to the sky. In Islamic architecture the interior surfaces of domes are usually decorated; however, there are also domes whose outer surfaces are decorated. There are few examples whose outer surfaces are decorated in Anatolia; domes with ornamented outer surfaces are seen particularly in Islamic structures in Egypt and Iran.

Thirty-nine examples of domes decorated with the wheel of fortune were identified in Turkish-Islamic architectural works. We can say with some certainty that this number may 
be even higher, considering that there may be examples that we could not trace or have not survived. Wheel of fortune motifs were made on the outside of four of them and the inside of 35 of them. The arms are evenly distributed, just like the moment of inertia principle, and their distance from each other is determined by the size of the dome and the number of arms. There isn't order or equality in the number of arms of the pinwheel used in the domes. The arms are in two different orders, those that are identical to each other and those that are full and empty. Among the examples we have identified, the minimum number of arms is present in the Nuşabad Ali Mosque (6 arms), and the most arms are in the dome of the Bursa Devlet Hatun Mausoleum (48 arms). The arms are designed to contrast with each other. Therefore, when we count both full and empty arms, we see twice the number of arms. Considering this, the highest number of arms is seen in the dome at the Malatya Great Mosque. The rotation direction of the arms is clockwise in 26 examples and counterclockwise in 13 examples. The arms are designed with even numbers, except for three examples. The earliest of the examples dates back to the 11th and 12 th centuries. The latest examples date to the 19th century. Seventeen of the wheel of fortune decorated domes are located in Iran, two in Egypt, one in Uzbekistan, and one in Bulgaria. The remaining examples are located within the borders of Turkey. 


\section{Giriş}

Alem, remiz, rumuz, timsal ve simge gibi kelimelerle eş anlamlı olan sembol kelimesi Yunanca "sumbolon” teriminden gelmektedir. "Antik Yunan'da bir çömlek parçası ikiye bölünmekte ve bu iki parçanın her biri kendi aralarında sözleşme yapan iki kişiye verilmekteydi. Sözleşme kapatılacă̆l an borçlu ya da borç veren kişilerin kendilerini tanıtmak maksadıyla ellerindeki iki kırık parçayı (sumballein) tam olarak birbirine ekleyebilmeleri gerekmekteydi. Böylece sumbolon terimi, yeniden birleştirildiklerinde ortak bir kökene sahip olduğunu ispat eden kırılmış bir nesnenin iki parçasını ifade etmek için kullanılmıştır. Dolayısıyla sembol, bir tanıma ve tanınma işareti niteliğinde olan nesneyi ifade etmektedir ${ }^{1}$ ". Her simge bilinç dışı bir içeriğin bilinçlenmesine yarar çünkü simgeler arka planlarındaki nesneyi ya da düşünceyi izleyiciye yansıtır. İnsanlar tarih boyunca güneş, dağ, rüzgar ve ateş gibi doğal nesneleri; kare, daire ve üçgen gibi soyut biçimleri ya da insan eli ile yapılmış nesneleri sembolleştirerek simgesel bir anlam katmışlardır². Semboller her toplumda, kültürde ve dilde farklılıklar göstermektedir. Örneğin dört rakamının diğer toplumlarda olumsuz bir anlamı yokken; Uzak Doğu toplumları, dört rakamı (si) ile ölüm kelimesi eş sesli olduğundan bu sözcügün kullanımından kaçınmışlardır ${ }^{3}$. Bunun yanında evrensel olan pek çok sembol de bulunmaktadır.

Türk süsleme sanatlarında bir eksen etrafında birden çok kolu ile döngüsel etki gösteren süslemelere çarkıfelek, firıldak ${ }^{4}$, pervane, yanar döner, oklu çark ${ }^{5}$, gök çığrısı ${ }^{6}$ ve tezginç ${ }^{7}$ gibi isimler verilmiştir. Arap ve İran kültürleri bu dönüş haline “çerh-i felek” demişlerdir. Türkler bunu çarkıfelek olarak Türkçeleştirmişlerdir". Çark-1 felek kelimesi Farsça "çerh" ve arapça "felek" kelimelerinin birleşiminden ortaya çıkmıştır. Çerh kelimesinin Farsçada tekerlek, çark, felek ve gökyüzü gibi anlamları bulunmaktadır?. Eski Türkçede “çığr”, Sanskritçede “çakra” kelimeleri ile benzerlik göstermektedir. Felek kelimesi ise gökyüzü, kader, talih, gök katmanı ve yörünge gibi anlamlara sahiptir ${ }^{10}$. Çark bir eksen etrafında ikiden fazla kolu ile dönen, pek çok çeşidi bulunan ekseriyetle daire biçimdeki parçaların genel ismidir ${ }^{11}$. En ilkel

1 Ramazan Adıbelli, Mircea Eliade ve Din Mircea Eliade’nin Din Bilimi Çalışmalarının Metodolojik Açısından Değerlendirilmesi, İstanbul, 2011, s. 130.

2 Aniela Jaffe, “Görsel Sanatlarda Sembol”, İnsan ve Sembolleri, Çev. Ali Nahit Babaoğlu, İstanbul, 2019, s. 232-238.

3 Wolfram Eberhard, Çin Simgeleri Sözlüğü, Çev. Aykut Kazancıgil, Ayşe Bereket, İstanbul, 2000, s. 100.

4 Yıldız Demiriz, İslam Sanatında Geometrik Süsleme, İstanbul, 2004, s. 60-62

5 Emel Esin, ““Kün-Ay” (Ay-Yıldız Motifinin Proto-Türk Devirden Hakanlılara Kadar İkonografisi)”, VII. Türk Tarih Kongresi, C.I, Ankara, 1972, s. 313-359,

6 Nermin Şaman Doğan, “Oklu Çakır/Oklu Çark/Gök Çığrısı: Selçuklu Süslemesinde Bir Motif”, I. Uluslararası Selçuklu Kültür ve Medeniyeti Kongresi Bildiriler, C.I, Konya, 2001, s. 243-249.

7 Ahmet Çaycı, Anadolu Selçuklu Sanatında Gezegen ve Burç Tasvirleri, Konya, 2019, s. 36.

8 Bahaeddin Ögel, Türk Mitolojisi, C.II, Ankara, 1995, s. 155.

9 Mehmet Kanar, “Çerh”, Osmanlı Türkçesi Sözlüğü, İstanbul, 2009, s. 607-608.

10 Mehmet Kanar, "Felek”, Osmanlı Türkçesi Sözlüğü, İstanbul, 2009, s. 949.

11 Alper Altın, "Türk-İslam Sanatı Geometrik Süslemesinde Ali İsminin Üç Kollu Çarka Uyarlanması”, Akademik Hassasiyetler, Sanat Tarihi Özel Sayısı, Ankara, 2019, s. 23-54. 
çark biçimi svastika denilen dört kollu olan çarktır ${ }^{12}$. Kare içerisinde döngüsel bir yapıda verilen svastikanın kökeninin M.Ö. 4000'li yıllara Mayalar ve Sümerler'e kadar uzandığ1 ifade edilmektedir. Hinduizm'e, Budizm'e ve Jainizm'e göre de kutsaldır. Svastikanın dört kolu, dört kozmik gücü (ateş, su, hava, toprak) simgelemektedir. Anadolu kültüründe aynı zamanda çarkıfelek motifi olarak da bilinmektedir ${ }^{13}$. Bunun yanı sıra en az svastika kadar eski olan triskelion denilen üç kollu çark da vardır. Tıpkı svastika gibi iyi şans simgesi olarak düşünülen form evrenin üç katmanlı doğası ile ilişkilendirilmektedir ${ }^{14}$. Anadolu'da görülen en eski sembollerden biri olan çarkıfelek, dünyanın ve evrenin devinimini, kaderi ve feleğin çemberini simgelemektedir. Bununla birlikte çarkıfelek, metafizik bir felsefenin yansımasıdır. Sıklıkla kullanılan çarkıfelek motifi Anadolu'daki Türk-İslam eserleri içerisinde cami, medrese, kervansaray, türbe ve mezar taşlarında karşımıza çıkmaktadır. Ayrıca çeşitli el sanatları ürünlerinde de bu motif görülmektedir ${ }^{15}$. Çarkıfelek motifi mimaride madalyonlara veya kabara üzerine işlendiği gibi kubbe gibi bir mimari elemanın içerisini kaplayarak göğe ait çağrışımlarda da bulunabilmektedir ${ }^{16}$.

Çarkıfelek kavramı tarihi kaynaklarda da ekseriyetle feleğin dönmesi şeklinde vurgulanmıştır. Örneğin Dîvânu Lugâti’t-Türk’te “Tanrı açını, alemi yarattı, felek durmadan döner."17 şeklinde, İbn-i Bibi’nin kaleme aldığı Selçukname'de “Güneş onun adaletinin gölgesine sığınır. Felek onun hükmünün merkezi etrafında döner." ${ }^{18}$ şeklinde, Evliya Çelebi'nin Seyahatnamesi'nde "Ve kırk yedi un değirmeni var ki her biri gece, gündüz çarkıfelek gibi dönmektedir"19 şeklinde, Feridüddin Attar'ın Esrarname adlı eserinde "Bu çarkıfelek seni döndürmeye başladı. Bir gram altına karşın yüz ayrık otu attı." ${ }^{20}$ ve Nizamüddin Şami’nin Zafername adlı eserinde "Bakalım, bu dönen felek kimin başını göklere yükseltecek yahut bu napayidar çarh bu defa kimi zelil ve hâr edecek." ${ }^{21}$ şeklinde geçmektedir. Aynı zamanda divan edebiyatına da tesiri görülmektedir. Dolayısıyla insanların hafızalarında geçmişten günümüze soyut bir kavram olarak varlığını sürdürmüş olan motifin somut olarak sanata yansıması da kaçınılmaz olmuştur.

12 Yusuf Çetin, "Türk-İslam Bezeme Sanatında Gamalı Haç (Svastika) ile Çarkıfelek Motiflerinin Köken ve İkonografik Anlamları Üzerine Bir Değerlendirme”, Social Sciences Studies Journal, C.3, S.8, İstanbul, 2017 , s. 353-365.

13 Nuray Gümüştekin, “Anadolu ve Diğer Kültürlerde İşaret ve Simgelerde Anlam”, Balıkesir Üniversitesi Sosyal Bilimler Dergisi, C.14, S.11, Balıkesir, 2011, s. 108.

14 J. C. Cooper, "Triquetra/Triskele/Fylfot", An Illustrated Encyclopaedia of Traditional Symbols, London, 1987, s. 181-182.

15 Beyhan Karamağaralı, "İçiçe Daire Motiflerinin Mahiyeti Hakkında”, Sanat Tarihinde İkonografik Araştırmalar Güner İnal'a Armağan, Ankara, 1993, s. 249.

16 Ahmet Çaycı, "Zaman ve Sanat Bağlamında Çark-1 Felek Motifi”, Uluslararası İslam Medeniyetinde Zaman Sempozyumu Bildiriler Kitabı, C.II, İstanbul, 2016, s. 304

17 Kaşgarlı Mahmud, Dîvânu Lugâti’t-Türk, C.II, Çev. Besim Atalay, Ankara, 1985, s. 303.

18 İbn-i Bibi, El Evamirü'l-Ala'iye Fi’l-Umuri’l-Ala'iye (Selçuk Name), C.I, Çev. Mürsel Öztürk, Ankara, 1996, s. 242.

19 Evliya Çelebi, Evliya Çelebi Seyahatnamesi, IX, İstanbul, 2005, s. 87.

20 Feridüddin Attar, Esrarname, Çev. Mehmet Kanar, 2013, s. 220.

21 Nizamüddin Şami, Zafername, Çev. Necati Lugal, Ankara, 1987, s. 261. 
Mircea Eliade, çarkıfeleğin halk inançları içerisinde tarih öncesi çağlara giden bir geçmişinin olduğunu bunların güneş merkezli inançlarla bağının olduğunu belirtmektedir ${ }^{22}$. İslam öncesi Türk inancına baktığımızda ise gök kubbenin altın ya da demir kazık ile yıldızları taşıyan gök çarkı etrafında döndüğü ifade edilmektedir ${ }^{23}$. Batlamyus'un dünya temelli eski astronomi anlayışında yerin çevresinde gök cisimlerinin muntazam bir şekilde dolandıkları kabul edilmektedir. Ay, Güneş ve diğer gezegenlerin sürekli dönüş durumundaki bu hareketinin gök cisimleri arasındaki mesafenin değişimine göre, insan hayatını olumlu ya da olumsuz yönde etkilediği ve kader üzerinde tesiri olduğu düşünülmektedir. Bundan dolayı çarkıfelek, iyi veya kötü talihin kaynağı olarak tahayyül edilmektedir ${ }^{24}$. Çarkıfeleğin yani kaderin bir tekerleğe benzetildiğini görmekteyiz. Örneğin zengin birinin sonradan fakirleşmesi veya fakir birinin zenginleşmesi kader çarkının tersine dönmesi şeklinde düşünülmüştür. Evliya Çelebi Seyahatnamesi'nde Habeşli Mehmed Kethüda'nın Derb-i Ahmer'de bir han ve bir sebil inşa ettiğini ve sonra felek müsaade etmeyerek hanı ve sebilhaneyi sattığından bahsetmektedir ${ }^{25}$. Burada yaptırmış olduğu mimari eserlerin satılmasının kaderin tesiri ile gerçekleştiğine inanılmaktadır. Yani standartlaşmış yaşam düzeninin devam etmesi çarkıfeleğin hareketi olarak, iyi ya da kötü yönde değişmesi ise çarkıfeleğin tersi yönde dönmesi olarak tasavvur edilmiştir. Feleğin çarkı bir yandan "ögüten, yok eden” kötü talih, diğer yandan "büyüten, çoğaltan” iyi talih anlamlarına haizdir. Çarktan geçebilenler acı çekmiştir ancak birtakım deneyimler de kazanmış, olumlu ve olumsuz tüm yanlarını da öğrenmiştir ${ }^{26}$. Bu kapsamda Batı sanatında "Wheel of Fortune" olarak bilinen şans tekerleğini Roma mitolojisinde tanrıça Fortuna'nın döndürdüğüne dair inanç ile çarkıfeleğin benzer olduğu görülmektedir.

Sözlük anlamı yarım küre biçimli yapı örtüsü olan kubbe, kemerler ile benzer geometrik tasarıma sahiptir. Kubbeler dikey eksende bir kemerin 180 derece döndürülmesi ile meydana gelmektedir ${ }^{27}$. Erken bir yapı biçimi olan kubbelerin daha çok daire biçimli yapıların sınırlarına uyma zorunluluğundan ortaya çıktığı düşünülmektedir ${ }^{28}$. Kubbenin kare mekanlarda kullanılması ilk defa Sasani yapılarında karşımıza çıkmaktadır. Firuzabad sarayındaki kare mekanlar, tromp geçişli kubbelerle kapatılmıştır ${ }^{29}$. Türkler kubbenin yapısal özelliğinin yanı sıra simgesel özelliğinden dolayı hem İslam öncesi dönemde hem de Türk-İslam döneminde mekanlarında faydalanmışlardır. Kadim dönemlerden beri yaşam alanlarının üzerini kubbe ile örtmeyi tercih

22 Mircea Eliade, Dinler Tarihine Giriş, Çev. Lale Arslan, İstanbul, 2003, s. 160-161.

23 Emel Esin, Türk Kozmolojisine Giriş, İstanbul, 2001, s. 42.

24 Mehmet Akif Duman, Şans Tanrıçası Fortuna'nın Tekerleği ile "Kader” İnancının Bir Unsuru Olarak "Çark-1 Felek”, Özne Felsefe ve Bilim Yazıları 21. Kitap - Felsefi Bir Sorun Olarak İnanma, Konya, 2015, s. 171.

25 Evliya Çelebi, Günümüz Türkçesi ile Evliya Çelebi Seyahatnamesi, Haz. Seyit Ali Kahraman, C.10/1, İstanbul, 2011, s. 306.

26 Ertan Daş, “Mezar Taşlarında Svastika ve Çarkıfelek Sembollerinin Kökeni ve Anlamı”, 1. Uluslararası Türkİslam Mezar Taşları Kongresi Bildiriler Kitabı, Aydın, 2018, s. 200.

27 Doğan Hasol, “Kubbe”, Ansiklopedik Mimarlık Sözlüğü, İstanbul, 1998, s. 280.

28 Doğan Kuban, "Kubbe”, Mimarlık Kavramları, İstanbul, 2002, s. 45-46,

29 George Rawlinson, The Seventh Great Oriental Monarchy or the Geography, History, and Antiquities of the Sassanian or New Persian Empire, C.II, New York, 1882, s. 244. 
eden Türkler, göçebe hayatın getirdiği zorluğu, pratikliği ile ön plana çıkan çadır yapıları ile çözmüşlerdir. Birkaç tip çadır olsa da ekseriyetle yurt tipi yuvarlak çadırları kullanmışlardır. Bu çadırların üzeri kubbe ile kapatılmıştır. Türkler makro kozmosunda gök örtüsü altında evrenin düzenini hissederken bu düzeni mikro ölçekte çadırın kubbesinde bulmuştur. Yani gökkubbe tasarımı ilk ifadesini çadırda yansıtmıştı ${ }^{30}$. Arkeolojik veriler yurt tipi çadırların kullanımını Hun dönemi öncesine M.Ö. 7. yüzyıla Tagar kültürüne kadar götürmektedir. Minnussinsk bozkırında Boyarı Dağı eteklerinde kaya üzerine çizilmiş petrogliflerdeki çadır tasvirleri bu kubbeli çadırların oldukça eski olduğunun göstergesidir ${ }^{31}$. Türk-İslam döneminde ise Karahanlı yapılarından başlanarak Selçuklu, Beylikler ve Osmanlı dönemlerinde inşa edilmiş olan cami, mescit, medrese, han, hamam ve türbe gibi pek çok yapı grubunda kubbe kullanıldığı görülmektedir.

Sanatçılar İslam yapılarının vazgeçilmez mimari ögelerinden biri olan kubbeyi zarif formlarının yeterli olduğundan dolayı süssüz ve sade bıraktıkları gibi bu kavisli satıhları tezyin ederek gerek iç yüzeylerini gerekse de dış yüzeylerini çeşitli motiflerle bezemişlerdir ${ }^{32}$. Taş, tuğla, alçı, çini ve kalemişi kullanılarak farklı malzeme ve tekniklerde süslenen kubbeler çevreden izole edilmiş mekandaki ilgiyi semaya doğru çekmektedir. İslam mimarisinde kubbelerin ekseriyetle iç yüzeyleri (karın) süslenmiştir. Bununla birlikte dış yüzeyleri (sırt) süslenen kubbeler de vardır. Anadolu'da dış yüzeyi süslenen örnek az olsa da özellikle Mısır³ ve İran'daki İslam yapılarında kubbelerin dış kısımlarının da bezendiği görülmektedir.

\section{Katalog}

Türk-İslam mimari yapılarında kubbenin yüzeyinin bütünüyle çarkıfelek motifi ile kaplandığ1 az sayıda örnek bulunmaktadır. Örnekler içerisinde kubbelerin genellikle iç yüzeyleri çarkıfelek motifi ile tezyin edilmiştir. Nadir de olsa dış yüzeylerinin çarkıfelek motifi ile bezendiği örnekler de vardır.

\section{Kaşan Sarnıcı (Ab Anbar)}

Türk-İslam mimarisinde bilinen çarkıfelek süslemeli kubbelerden en erken tarihlisi İran'da yer almaktadır. Kaynakların belirttiğine göre Kaşan Kalesi ile aynı tarihlerde Büyük Selçuklu döneminde 11-12. yüzyılda yapıldığı düşünülmektedir ${ }^{34}$. Sarnıç (Ab Anbar) dıştan kademeli bir şekilde yükselen konik külahla içten kubbe ile örtülmüştür. İçteki kubbenin karnında sırlı ve sırsız tuğla ile yapılmış çarkıfelek süslemesi karşımıza çıkmaktadır. Sırlı tuğla ile yapılan kollar kıvrımlı bir şekilde kubbenin merkezindeki açıklıktan başlamakta ve kubbe içerisindeki

\footnotetext{
30 Semra Ögel, Anadolu'nun Selçuklu Çehresi, İstanbul, 1994, s. 64.

31 Nejat Diyarbekirli, Hun Sanatı, İstanbul, 1972, s. 61.

32 Daud Sutton, Islamic Design a Genius for Geometry, Bloomsbury, 2007, s. 46.

33 Barbara Cipriani, Development of Construction Techniques in the Mamluk Domes of Cairo, Venezia Üniversitesi Mimarlık Enstitüsü Yayınlanmamış Yüksek Lisans Tezi, Venedik, 2005, s. 31.

34 Osman Eravşar-Haşim Karpuz, Büyük Selçuklu Mirası Mimari, C.2, İstanbul, 2013, s. 118.
} 
yatay süsleme şeridinde son bulmaktadır. Kubbe içerisindeki sırlı tuğlalar düşmüş, sadece sırlı tuğlaların kare yuvaları günümüze gelebilmiştir. Kubbede dolu-boş olarak meydana getirilmiş tahminen yirmi iki kol bulunmaktadır (F.1a, F.1b).

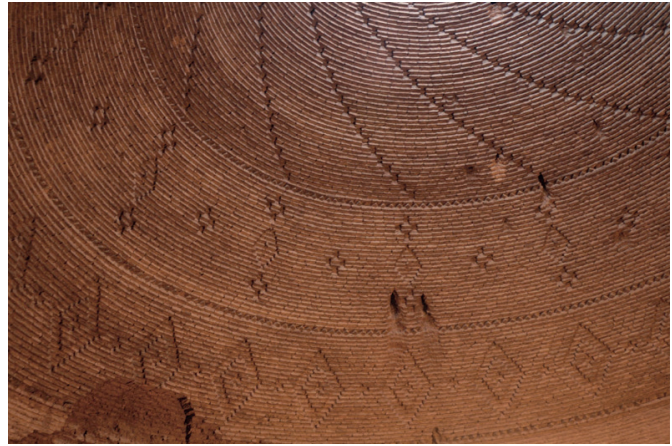

Figure 1a: İran Kaşan Sarnıcı Kubbe Süslemesi (Kaynak: http://www. selcuklumirasi.com/architecturedetail/kasan-sarnic)

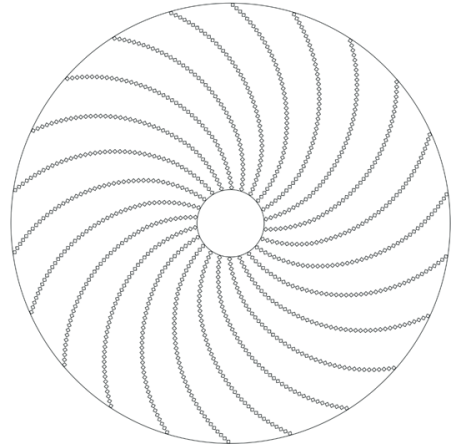

Figure 1b: İran Kaşan Sarnıcı Kubbe Süslemesi Çizimi

\section{Malatya Ulu Camisi}

Alâeddin Yakup oğlu Mansur tarafından Keykubat döneminde 1224 yılında ${ }^{35}$ yaptırılan Malatya Ulu Camisi kubbe-eyvan birleşiminin uygulandığ 1 bir plan tipindedir. Caminin mihrap önü, üç dilimli tromp geçişli ve yüksek kasnaklı bir kubbe ile kapatılmıştır ${ }^{36}$. Tamamen tuğladan yapılan kubbenin iç yüzeyi sırlı ve sırsız tuğla kullanılarak bezenmiştir. Kubbe göbeğinde dairesel bir madalyon yer almaktadır. Madalyonun etrafında birkaç intizamsız sırlı tuğla sırasından sonra kıvrımlı fïuze renkli sırlı tuğla kollar görülmektedir. Çarkıfelek motifi dolu-boş kırk bir kollu yapılmıştır (F.2a, F.2b). Çarkıfelek motifinin aslında kubbe göbeğindeki madalyondan başlayarak eteklere kadar geldiği, madalyonun etrafındaki düzensiz sıraların sonraki onarım neticesinde olduğu iddia edilmektedir ${ }^{37}$.

35 M. Oluş Arık, "Malatya Ulu Camiinin Asli Planı ve Tarihi Hakkında", Vakıflar Dergisi, S.8, Ankara, 1969, s. 144.

36 Muhammet Arslan, Anadolu'da Selçuklu Çağı Cami ve Mescit Mimarisi (Plan-Mimari-Süsleme), Atatürk Üniversitesi Sosyal Bilimler Enstitüsü Yayınlanmamış Doktora Tezi, Erzurum, 2016, s. 978.

37 Alper Altın, Anadolu Selçuklu Mimarisindeki Geometrik Süslemelerde Restorasyon Hataları, Konya, 2020, s. 186. 


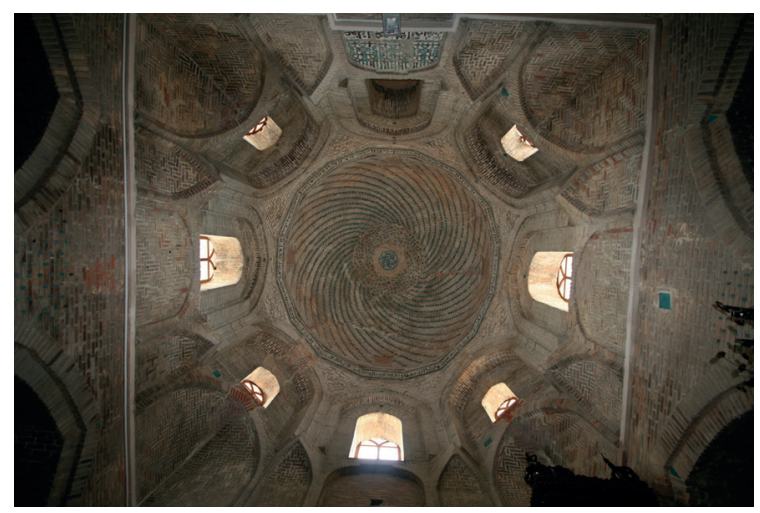

Figure 2a: Malatya Ulu Camisi Kubbe Süslemesi (Alper Altın, 2013)

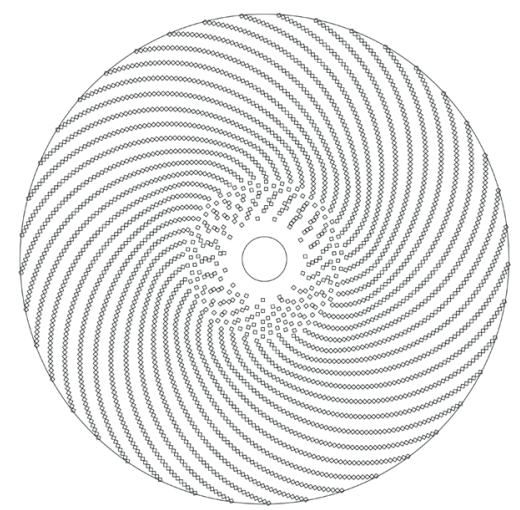

Figure 2b: Malatya Ulu Camisi Kubbe Süslemesi Çizimi

\section{Konya İç Karaaslan Mescidi}

Sultan Alaeddin Keykubat zamanında 1233 yılında inşa edilmiştir ${ }^{38}$. Kare mescidin üzerini örten tuğla kubbenin iç yüzeyi bütünüyle çarkıfelek motifi ile tezyin edilmiştir. Çarkıfelek, yatay tuğla sıralarının arasına dikey konumda yerleştirilen tuğlalarla yapılmış dolu-boş otuz bir yay biçimli koldan meydana gelmektedir. Motif, kubbe göbeğindeki dairesel çini madalyondan başlayarak kubbe eteklerine kadar uzanmaktadır (F.3a, F.3b).

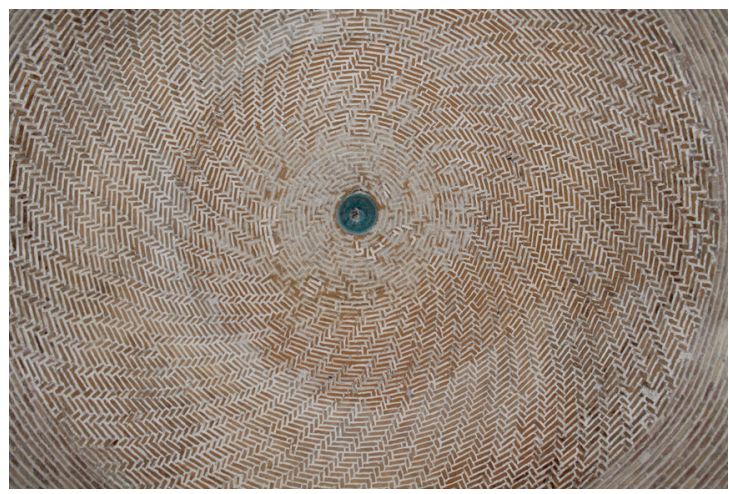

Figure 3a: Konya İç Karaaslan Mescidi Kubbe Süslemesi (Muhammet Arslan, 2013)

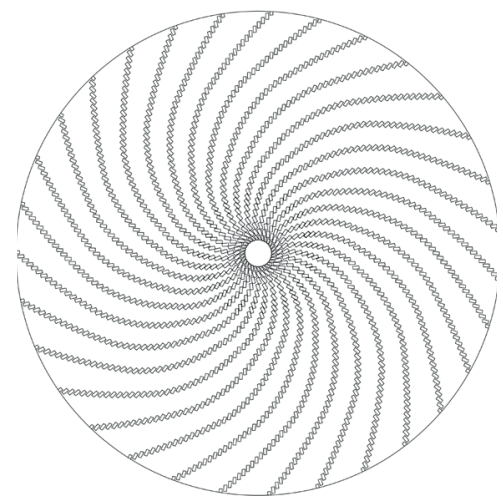

Figure 3b: Konya İç Karaaslan Mescidi Kubbe Süslemesi Çizimi

38 Zekeriya Şimşir-Ahmet Yavuzyılmaz, "Yeni Bulunan Bir Selçuklu Kitabesi: İç Karaarslan Mescidi Kitabesi", Selçuk Üniversitesi Sosyal Bilimler Enstitüsü Dergisi, Prof. Dr. Fuat Sezgin Özel Sayısı, Konya 2019, s. 94-96. 


\section{Kahire Emir el-Câî (İlgay) Yusuf Türbesi}

Bahri Memlukler döneminde Nasır'ın torunu “el-Eşref” unvanıyla bilinen Zeyneddin II. Şaban'ın emirlerinden biri olan El-Cai Yusuf tarafından 1373 yılında külliye olarak Mısır'ın Kahire şehrinde inşa edilmiştir. Külliye içerisinde medrese, sebil-i küttab ve türbe yer almaktadır ${ }^{39}$. Çarkıfelek süslemeli kubbe, türbededir. Silindirik kasnak üzerinde yükselen kubbenin sırtına çarkıfelek süslemeli bezeme yapılmıştır. Çarkıfelek motifi, kubbenin merkezindeki alemden başlayarak kubbe eteğinde son bulan dolu-boş kollardan oluşmaktadır. Burada kalın nervürlerle meydana getirilmiş tahminen yirmi sekiz kıvrımlı kol vardır (F.4).

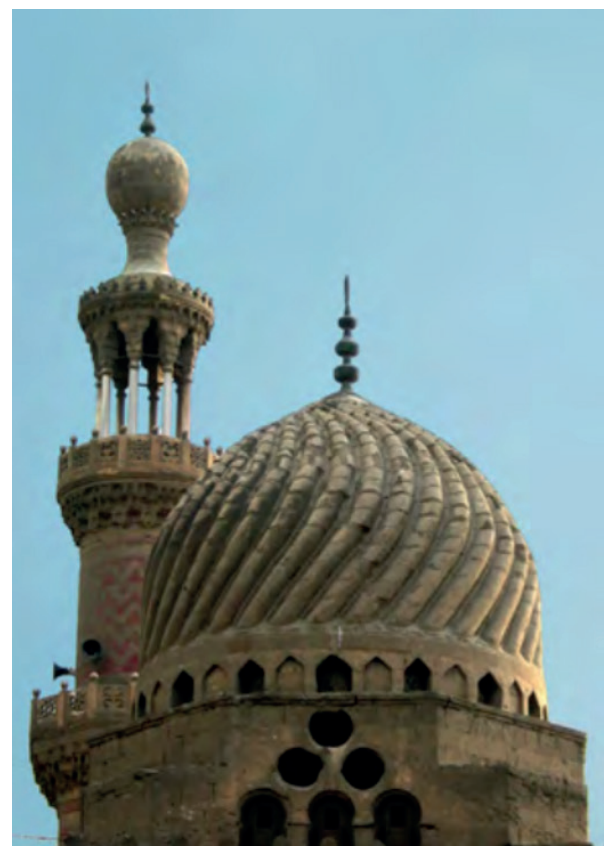

Figure 4: Misır-Kahire Emir İlgay Yusuf Türbesi Kubbe Süslemesi (Kaynak: https://akpia.mit. edu/sites/default/files/images/sympdomesposter.pdf)

\section{Selçuk İsa Bey Camisi}

Aydınoğulları Beyliği döneminde 1375 yılında İsa Bey tarafından yaptırılmıştır ${ }^{40}$. Cami, mihraba paralel uzanan iki sahınlı düzeni ile Suriye etkisi göstermektedir. Avluya açılan batıdaki taçkapının hemen arkasında, minare ile beden duvarı arasında kalan birimin üzeri merkezinde kubbecik olan yıldız tonozla kapatılmıştır. Merkezde yer alan kubbecik sekizgen bir kasnak üzerinde yükseltilmiştir. Kubbeciğin karnında on altı kavisli kol ile yapılan çarkıfelek süslemesi karşımıza çıkmaktadır (F.5a, F.5b).

39 Dorıs Behrens-Abouseif, Islamic Architecture in Cairo an Introduction, Leiden, 1998, s. 131.

40 Selda Ertuğrul, "Îsâ Bey Camii”, DİA, C.22, İstanbul, 2000, s. 477. 


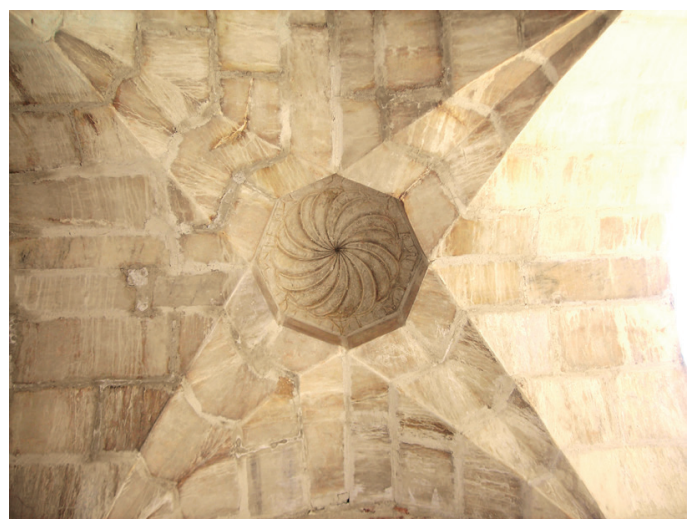

Figure 5a: İzmir Selçuk İsa Bey Camisi Kubbecik Süslemesi (Mehmet Öztürk, 2011)

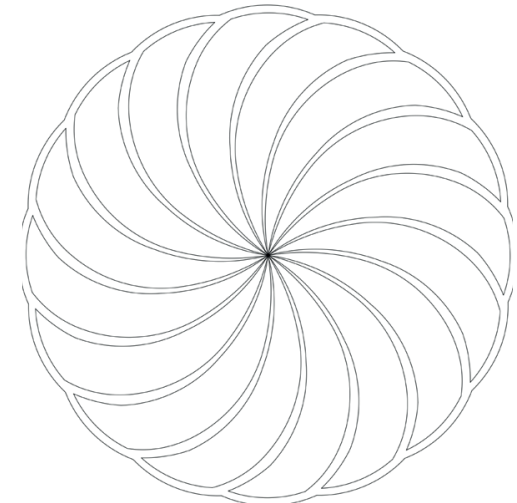

Figure 5b: İzmir Selçuk İsa Bey Camisi Kubbecik Süslemesi Çizimi

\section{Kahire Ayıtmış Türbesi}

Bahri Memlukler döneminde cami, türbe ve sebilden oluşan külliye halinde inşa edilmiştir. Sultan Berkuk zamanında Atabek'ül Asakiriye görevinde bulunan emir Ayıtmış tarafından 1383 yılında yaptırılmıştır ${ }^{41}$. Türbenin üzeri dıştan yüksek tutulmuş iki kademeli kasnak üzerine yerleştirilmiş kubbe ile örtülmüştür. Kubbenin sırtı kalın nervürlerle meydana getirilmiş çarkıfelek süsleme ile bezenmiştir. Dolu-boş olarak yapılmış takribi yirmi dört kol mevcuttur. Kubbenin merkezindeki alemden başlayan nervürler kıvrılarak kubbe eteğine kadar devam etmekte ve kasnakta düz bir şekilde nihayetlenmektedir. Eski fotoğraflarda tek renk olduğu görülen dikey silmelerin daha sonraki onarımlarda birer atlamalı olarak boyandığ1 görülmektedir (F.6).

41 Caroline Williams, Islamic Monuments in Cairo the Practical Guide, Cairo, 2008, s. 81-82. 


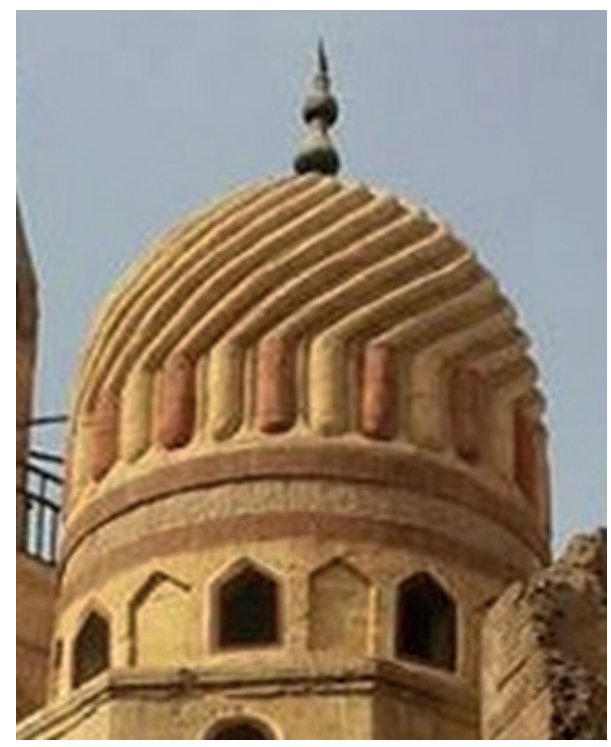

Figure 6: Mısır-Kahire Ayıtmış Türbesi Kubbe Süslemesi (Kaynak:https://lh5. googleusercontent.com/p/AF1QipOtcBC9gjIwgePn2nkjurn6OsiHPERiiO9PUmmB=w600h988-p-k-no)

\section{Bursa Yıldırım Hamamı}

Osmanlı döneminde Yıldırım Bayezid tarafından 1390 yılında külliyenin bir parçası olarak yaptırılan hamam küçük ölçekli olarak inşa edilmiştir. Sıcaklık etrafında sıralanan halvet hücreli hamamlar grubundaki yapıda çarkıfelek süslemeli kubbe, 1lıklık mekanında yer almaktadır. Çarkıfelek süslemesi dairevi nervürlerle yapılmıştır ${ }^{42}$. Takribi yirmi dört kıvrımlı kola sahip çarkıfelek dolu-boş biçimde tasarlanmıştır. Kollar, kubbe göbeğindeki aydınlık fenerinden başlayarak kubbe eteğine kadar devam etmekte ve kubbe eteğinde dalgalı bir şekilde sonlanmaktadır (F.7a, F.7b).

42 Can Keklik, Bursa, Erken Dönem Osmanlı Hamamları, Marmara Üniversitesi Sosyal Bilimler Enstitüsü Yayınlanmamış Yüksek Lisans Tezi, İstanbul, 1996, s. 36. 


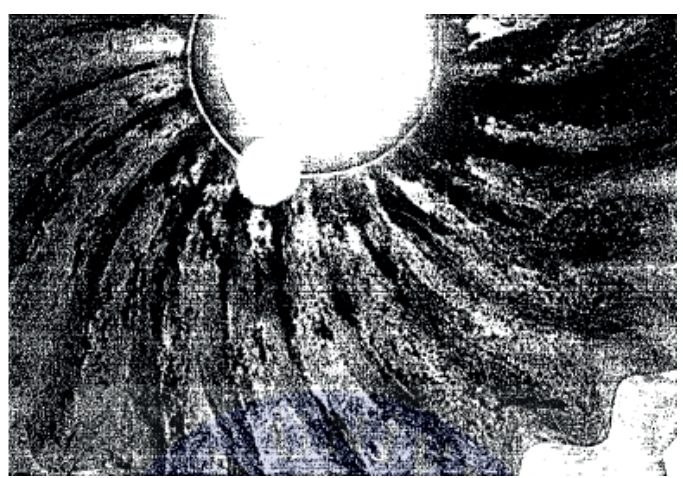

Figure 7a: Bursa Yıldırım Hamamı Kubbe Süslemesi (Keklik, 1996, Resim 41)

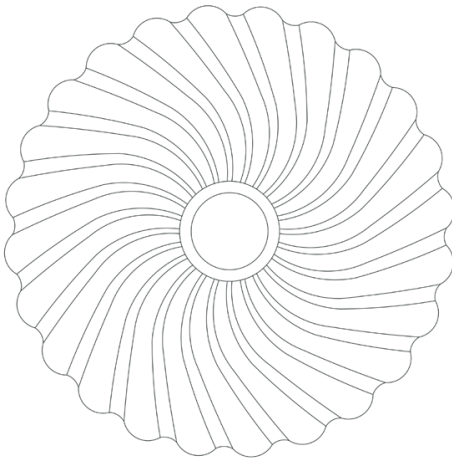

Figure 7b: Bursa Yıldırım Hamamı Kubbe Süslemesi Çizimi

\section{Amasya Bayezid Paşa Camisi}

Osmanlı döneminde Çelebi Mehmet'in lalası Bayezid Paşa tarafından 1414 yılında inşa ettirilen yapı tabhaneli camiler plan tipindedir ${ }^{43}$. Caminin kuzeyinde beş kemer gözlü bir son cemaat yeri bulunmaktadır. Son cemaat yerinin doğu kenarındaki kemer gözünün üst örtüsü diğerlerinden farklı yapılmıştır. Türk üçgeni geçişli kubbenin karnı çarkıfelek süsleme ile bezenmiştir ${ }^{44}$. Buradaki çarkıfelek süslemesinin on altı kollu olduğu belirtilmektedir ${ }^{45}$. Ancak çarkıfeleğin dolu-boş olarak yapılmış on iki kolu bulunmaktadır. Merkezden başlayarak kubbenin eteğinde sonlanan kollar kıvrımlı sivri yivlerle meydana getirilmiştir (F.8a, F.8b).

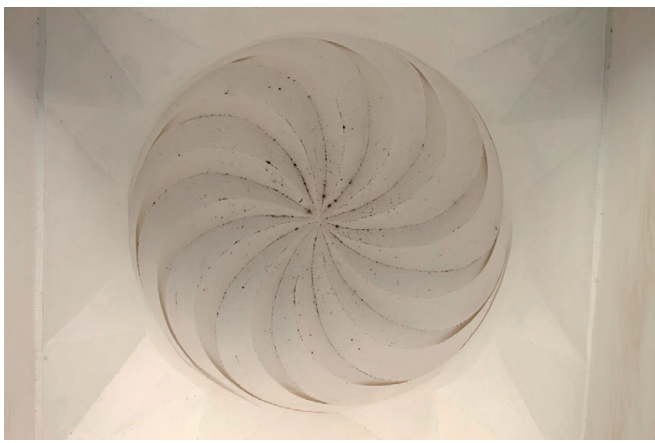

Figure 8a: Amasya Bayezid Paşa Camisi Kubbe Süslemesi (VGMA, 2009)

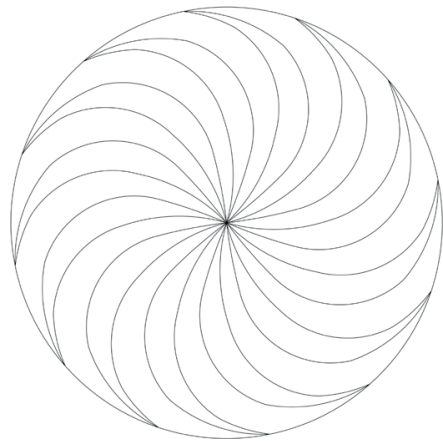

Figure 8b: Amasya

Bayezid Paşa Camisi Kubbe Süslemesi Çizimi

43 Semavi Eyice, "Bayezid Paşa Camii”, Di̇A, 5, İstanbul, 1992, s. 243.

44 Albert Gabriel, Monuments Turcs D’anatolie, C.II, Paris, 1934, s. 25-27.

45 Ekrem Hakkı Ayverdi, Osmanlı Mimarisinde Çelebi ve II. Sultan Murad Devri 806-855 (1403-1451), İstanbul, 1989 , s. 9. 


\section{Bursa Devlet Hatun Türbesi}

Bursa merkezinde yer alan türbe Çelebi Mehmet tarafindan annesi Germiyanoğlu Yakup Bey'in kızı Devlet-Hatun adına 1414 yılında yaptırılmıştır. Kare planlı dört köşe ayağın taşıı̆ı̆ı baldaken biçimdeki türbenin merkezinde tek sanduka bulunmaktadır. Ayakların arasına birer sütun yerleştirilerek her bir cephede iki sivri kemerli açıklık meydana getirilmiştir. Türbenin üst örtüsü içten kubbe dıştan ise konik bir külahla örtülmüștür ${ }^{46}$. Türbenin kubbe karnı birbirine eş kırk sekiz kola sahip çarkıfelekle bezenmiştir. Kollar, birer atlamalı olarak düşünülürse yirmi dört kollu olduğu belirtilebilir. Merkezdeki madalyondan çıkan kollar içbükey kavisli silme ile yapılmıştır. Her bir dilim içerisine kalemişi ile birbirine eş muhdes bitkisel süslemeler işlenmiştir (F.9a, F.9b).

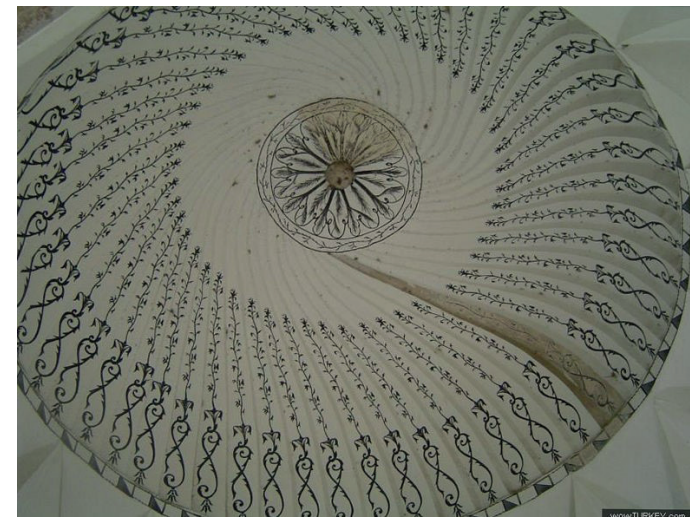

Figure 9a: Bursa Devlet Hatun Türbesi Kubbe Süslemesi (Kaynak:http://wowturkey. com/forum/viewtopic.php?t=54860)

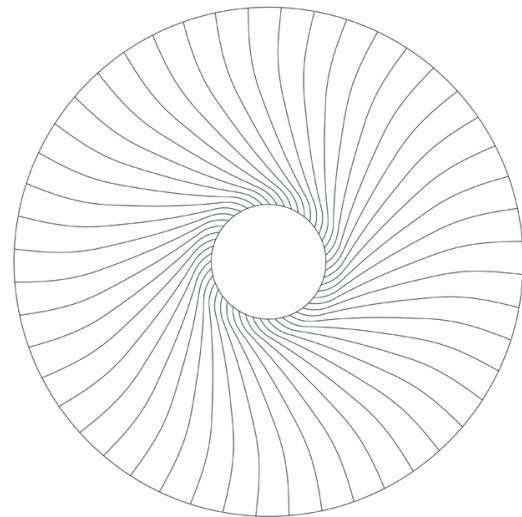

Figure 9b: Bursa Devlet Hatun Türbesi Kubbe Süslemesi Çizimi

\section{Edirne Gazi Mihail Hamamı}

Osmanlı döneminde 1422 yılında Gazi Mihail Bey tarafindan hamam, cami, imaret ve köprüden oluşan külliyenin bir parçası olarak inşa edilmiş̧ir. Yapı plan olarak asimetrik düzende çifte hamam olarak yaptırılmıştır. Hamamın erkekler bölümünün sıcaklığı iki eyvanlı, iki halvetlidir ${ }^{47}$. Çarkıfelek süslemeli kubbenin bulunduğu ılıklık kare planlıdır. Mekanın üzeri Türk üçgeni geçişli kubbe ile örtülmüştür. Kubbenin karnı, merkezdeki aydınlık fenerinden eteklere kadar çarkıfelek süsleme ile bezenmiştir. On altı kollu çarkıfelek dolu-boş şekilde yapılmıştır. Çarkıfeleğin kollarında sivri nervürlü ve düz yüzeyler kullanılmıştır. Düz yüzeylerin her birine üçer filgözü pencere açılmıştır. Kollar, kubbenin eteklerinde Türk üçgenleri ile aynı şekilde sonlanmakta ve kubbe eteğinde on altı köşeli yıldız biçiminde bir kasnak meydana getirmektedir (F.10a, F.10b).

46 Orhan Cezmi Tuncer, Anadolu Kümbetleri 2 Beylikler ve Osmanlı Dönemi, Ankara, 1991, s. 131.

47 Doğan Kuban, "Edirne'de Bazı İkinci Murat Çağı Hamamları Mukarnas Bezemeleri Üzerine Notlar”, Ord. Prof. İsmail Hakkı Uzunçarşılı’ya Armağan, Ankara, 1976, s. 453-454. 


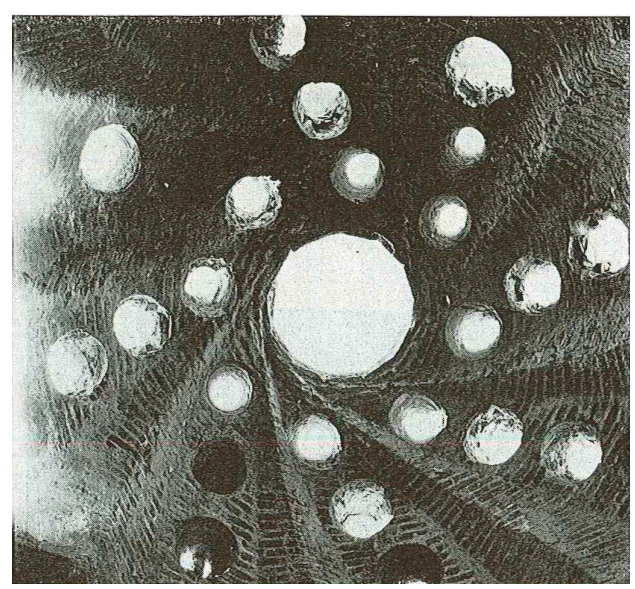

Figure 10a: Edirne Gazi Mihal Hamam1 Kubbe Süslemesi (Kuban, 1976, Şekil 8a)

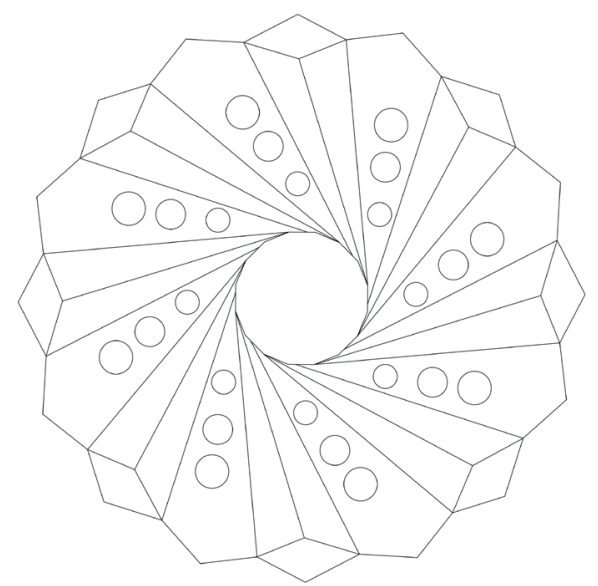

Figure 10b: Edirne Gazi Mihal Hamamı Kubbe Süslemesi Çizimi

\section{Bursa Tavuk Pazarı Hamamı}

Vakfiyesine göre 1426 yllında Sultan II. Murad tarafindan Muradiye Camisi'ne gelir getirmesi amacıyla çifte hamam olarak yaptırılmıştır. Kadınlar ve erkekler kısmı asimetrik düzende sıralı soyunmalık, 1lıklık ve sıcaklığa sahiptir ${ }^{48}$. Çarkıfelek bezemeli kubbe erkekler bölümünün 1lıklık mekanındadır ${ }^{49}$. Kare 1lıklık bölümü doğu yönde bir eyvanla genişletilmiştir. Dikdörtgen eyvan Türk üçgeni geçişleri ile kareye dönüştürülmüş merkezde kubbe ile kapatılmıştır. Kubbenin karnı göbekteki dairesel aydınlık feneri açıklığından itibaren eteklere kadar uzanan çarkıfelekle bezenmiştir. Dolu-boş şekilde yapılmış çarkıfelek tahminen kavisli yirmi sekiz kolludur (F.11a, F.11b). 


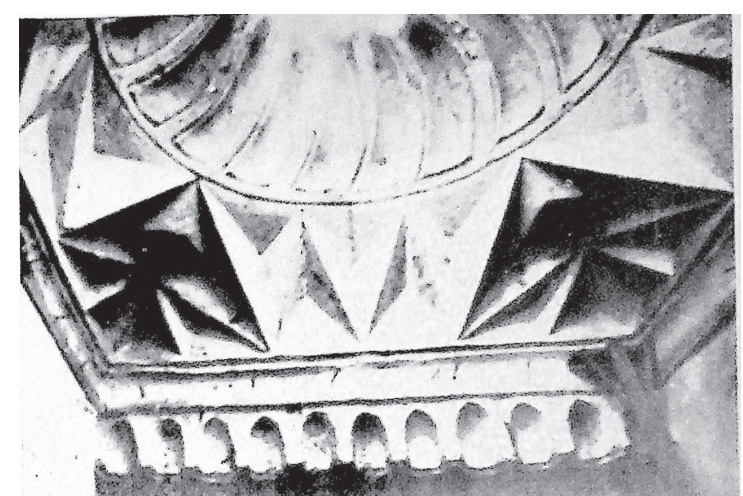

Figure 11a: Bursa Tavuk Pazarı Hamamı Kubbe Süslemesi (Ayverdi, 1989, Resim 632)

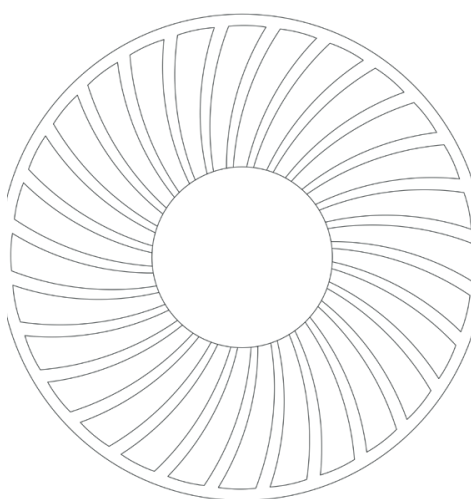

Figure 11b: Bursa Tavuk Pazarı Hamamı Kubbe Süslemesi Çizimi

\section{Bursa Emir Sultan Hamamı}

Külliyenin parçası olarak yapılan hamam vakfiyesine göre Yıldırım Bayezid'in kızı Hindu Hatun tarafından eşi Emir Sultan adına 1426 yılında yaptırılmıştır. Kuzey-güney doğrultusunda dikdörtgen planlı hamam sıralı soyunmalık, 1lıklık ve sıcaklık birimlerine sahiptir ${ }^{50}$. Kare planlı 1lıklık mekanının üzeri kubbe ile örtülmüştür. Kubbenin karnı yirmi dört kollu çarkıfelek ile bezenmiştir. Çarkıfelek, kubbenin göbeğindeki dairesel aydınlık fenerinden başlayarak kavisli bir şekilde kubbe eteğine kadar uzanmaktadır. Dolu-boş tasarlanan çarkıfelek, kubbe eteğinde iki sıra dalga yaparak son bulmaktadır (F.12a, F.12b). 


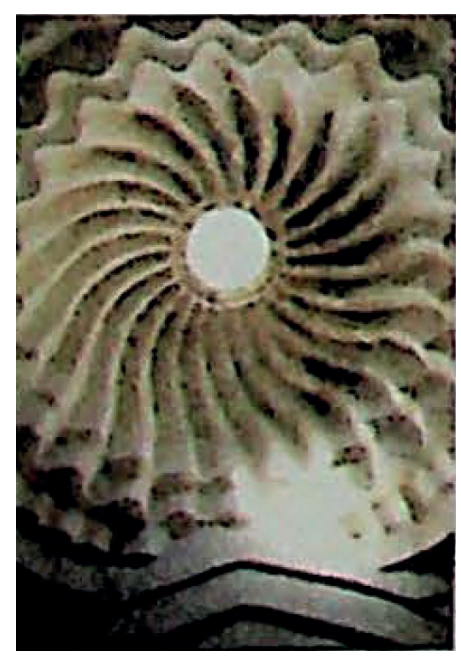

Figure 12a: Bursa Emir Sultan Hamamı Kubbe Süslemesi (Şehitoğlu, 2008, s. 56)

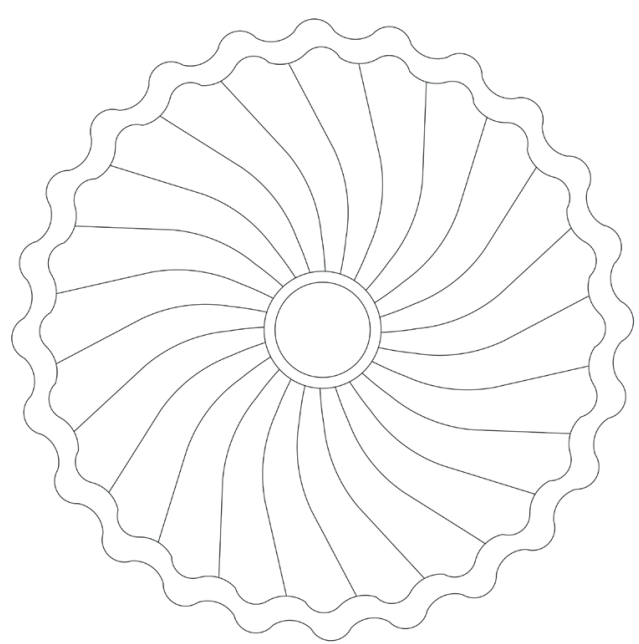

Figure 12b: Bursa Emir Sultan Hamamı Kubbe Süslemesi Çizimi

\section{Bergama Küplü Hamamı}

Hamamın kitabesi bulunmasa da 1427 tarihli vakfiyesinden hareketle yapıyı Hatip Mahmut Paşa'nın söz konusu tarihten önceki yılda yaptırdığı belirtilmektedir ${ }^{51}$. Tek eyvanlı ve köşe halvetli sıcaklığa sahip hamamın merkezi mukarnas dolgulu pandantif geçişli, sekizgen kasnaklı ve çarkıfelek bezemeli bir kubbe ile örtülmüştür. Kubbenin merkezinde filgözü pencere yer almaktadır. Merkezdeki filgözünden başlayarak kalın nervürlerle dolu-boş olarak yapılmış on altı kıvrımlı kol görülmektedir. Kıvrımlı kolların ayırdığı dilimlerin her birinin arasında üçer adet filgözü mevcuttur. Filgözleri kıvrıma uyacak şekilde yerleştirilmiştir. Böylece hem silmelerle hem de filgözleriyle çarkıfelek vurgulanmıştır (F.13a, F.13b).

51 Sevgi Soyaker, "Bergama'da Türk Hamamları”, Bergama Belleten, S.2, İzmir, 1992, s. 30. 


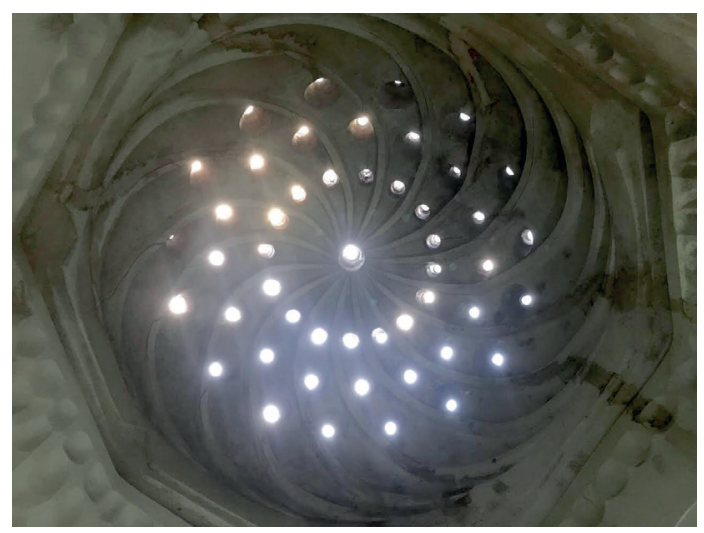

Figure 13a: Bergama Küplü Hamamı Kubbe Süslemesi (Selim Okat, 2019)

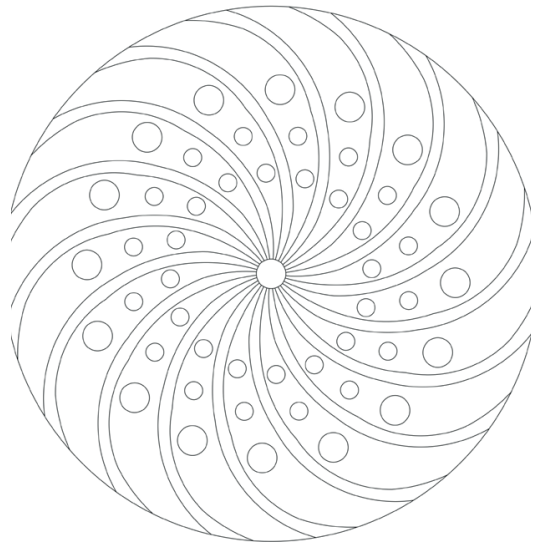

Figure 13b: Bergama Küplü Hamamı Kubbe Süslemesi Çizimi

\section{Bursa Kayıhan Hamamı}

Osmanlı döneminde Bursa'da Veziriazam Koca Mehmed Ağa tarafindan camisine gelir getirmesi amacı ile yaptırılmıştır. Kesin yapım tarihi bilinmeyen hamamın Paşa'nın ölüm tarihi olan 1439 yılından önce yaptırıldığı ifade edilmektedir ${ }^{52}$. Çifte hamam olarak inşa ettirilen hamamın kadınlar ve erkekler bölümü simetrik bir düzen sergilememektedir. Sıcaklık etrafına halvetlerin yerleştirildiği görülmektedir. Doğu kenarda yer alan erkekler bölümünün 1lıklık kubbesi diğerlerinden farklı olarak çarkıfelek süslemesi ile bezenmiştir. Dikdörtgen 1lıklık mekanı kemerlerle kareye dönüştürülmüş ve üzeri kubbe ile kapatılmıştır. Dolu-boş kıvrımlı kollarla yapılan çarkıfelek tahminen yirmi kola sahiptir. Kollar merkezdeki büyük aydınlık feneri açıklığından başlamakta ve kubbe eteğinde sonlanmaktadır (F.14a, F.14b).

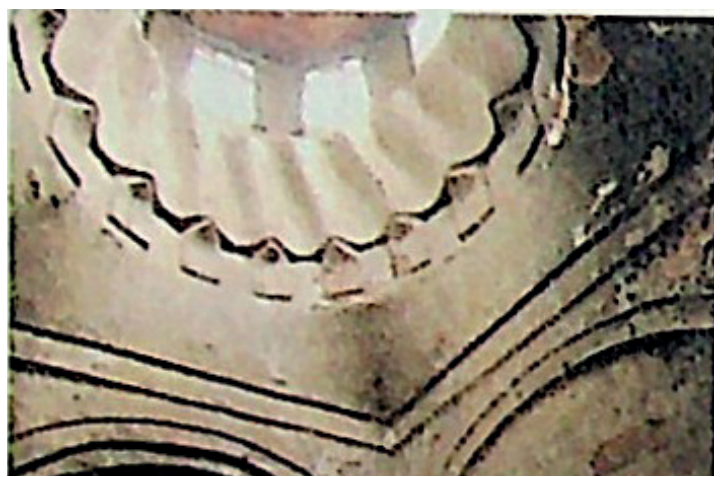

Figure 14a: Bursa Kayıhan Hamamı Kubbe Süslemesi (Şehitoğlu, 2008, s. 68)

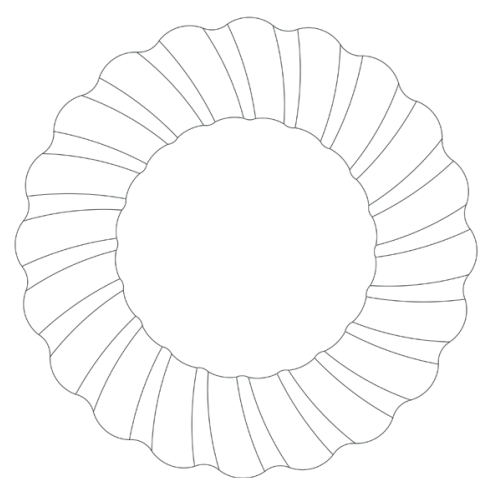

Figure 14b: Bursa Kayıhan Hamamı Kubbe Süslemesi Çizimi

52 Şehitoğlu, a.g.e., s. 67. 


\section{5. İznik İsmail Bey Hamamı}

İznik’te inşa tarihi ve banisi bilinmeyen yapının küçük ölçekli özel bir hamam olduğu belirtilmektedir. Hamamın diğer adı Selçuk Hamamı olarak geçse de bunun ne sebeple verildiği meçhuldür. Yapının ahşap sarayın müştemilatı olduğundan dolayı 14-15. yüzyıllarda inşa edilmiş olabileceği ifade edilmektedir ${ }^{53}$. Hamam dört küçük birimden meydana gelmektedir. Dikdörtgen planlı 1lıklık mekanı mukarnaslı geçişlerle kareye dönüştürülmüş ve üzeri kubbe ile kapatılmıştır. Kubbenin karnı nervürlü sarmal kollarla yapılan çarkıfelek süsleme ile bezenmiştir. Kubbe göbeğindeki aydınlık fenerinden başlayarak kıvrımlı bir şekilde kubbe eteğine kadar dolu-boş kollarla yapılmış on iki dilim görülmektedir. Nervürlü kolların arasındaki satıhta çok sayıda filgözü pencere açılmıştır. Hem nervürlü kollar hem de filgözlerinin olduğu satıhlar iki ayrı çarkıfelek görüntüsü yansıtmaktadır. (F.15a, F.15b)

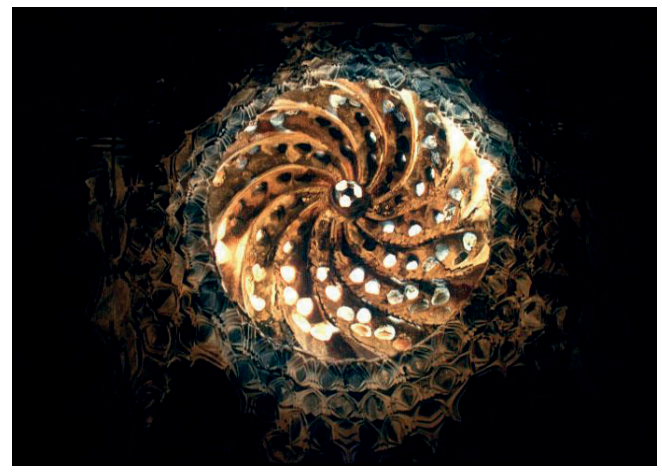

Figure 15a: İznik İsmail Bey Hamamı Kubbe Süslemesi (Kaynak: https:// edebistan.com/haberler/ruhunkubbesi-iznik)

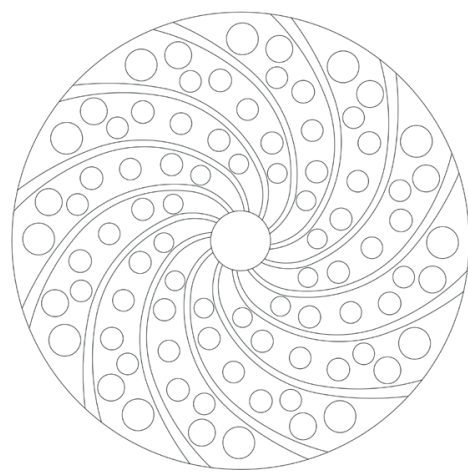

Figure 15b: İznik İsmail Bey Hamamı Kubbe Süslemesi Çizimi

\section{Edirne Kumkasrı Hamamı}

Edirne'de Saray-1 Cedîd-i Âmire (Yeni Saray) yapılarından biri olan hamamın sarayla beraber II. Mehmed döneminde 15. yüzyıl ortalarında inşa edilmiş olduğu belirtilmektedir ${ }^{54}$. Hamam yapıya ismini veren Kum Kasrı ile birlikte II. avlunun kuzeyinde yer almaktadır. Eski fotoğraflarda görülebilen Kum Kasrı günümüze gelememiştir. Mütevazi küçük boyutlarda tipik bir saray hamamı olan yapının iki bölümlü sıcaklığı bulunmaktadır. Diğerinden büyük olan dikdörtgen planlı asıl sıcaklık bölümü sivri kemerle ikiye bölünmüş, kare alanın üzeri pandantif geçişli kubbe ile kapatılmıştır. Kubbe içerisinde çarkıfelek motifi yapılmıştır. Çarkıfelek dolu-boş yapılmış on iki kola sahiptir. Merkezdeki dairesel madalyondan çıkan kollar kubbe eteklerinde nihayetlenmektedir. Girintili yapılmış kollar kubbe eteklerinde

53 Semavi Eyice, "İsmail Bey Hamamı”, DİA, 23, İstanbul, 2001, s. 86.

54 Mustafa Özer-Mesut Dündar, "Edirne Sarayı Kum Kasrı Hamamı ve Aşçılar Hamamı”, Akdeniz Sanat Dergisi, S.19, Antalya, 2019, s. 573. 
kemercikle sonlanmıştır. Atlamalı olarak girintili kollar içerisine birer filgözü pencere yerleştirilmiştir (F.16a, F.16b).

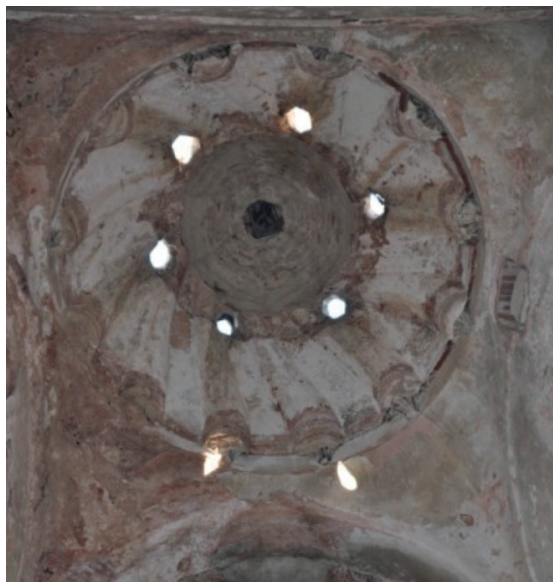

Figure 16a: Edirne Kumkasrı Hamamı Kubbe Süslemesi (Mustafa Özer, 2014)

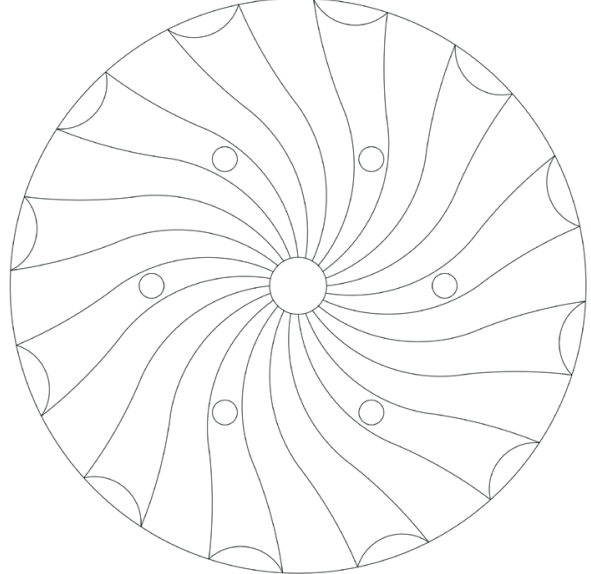

Figure 16b: Edirne Kumkasrı Hamamı Kubbe Süslemesi Çizimi

\section{Edirne Yeniçeri Hamamı}

Hamamın inşası ve banisi hakkında kesin bir bilgi yoktur. Ancak Beylerbeyi Hamamı'nın banisi Yusuf Sinaneddin Paşa'nın bu hamamı da yakın tarihlerde, 15. yüzyılın ilk yarısında yaptırdığı belirtilmektedir ${ }^{55}$. Plan ve süsleme özellikleri ile yapının II. Murat dönemine girdiği ifade edilmektedir ${ }^{56}$. Soyunmalık kısmı günümüze gelemeyen yapının sıcaklık bölümü iki eyvanlı ve köşe halvetli yapılmıştır. Kuzeybatı köşede yer alan halvet üçgen bingilerle geçilen kubbe ile örtülmüştür. Kubbe sivri yivli çarkıfelek süslemesine sahiptir. Merkezdeki aydınlık fenerinden başlayarak aşağıya doğru genişleyen birbirine eş on altı kola sahiptir. Kollar kubbe eteğinde üçgen bingilerle aynı şekilde sonlanmakta ve kubbe eteğinde on altı köşeli yıldız biçiminde bir kasnak meydana getirmektedir. Benzer şekilde on altı köşeli yıldız kubbe göbeğinde de görülmektedir (F.17a, F.17b).

55 Sabih Erken, "Edirne Hamamları", Vakıflar Dergisi, S.10, Ankara, 2006, s. 411.

56 Kuban, a.g.e., s. 455. 


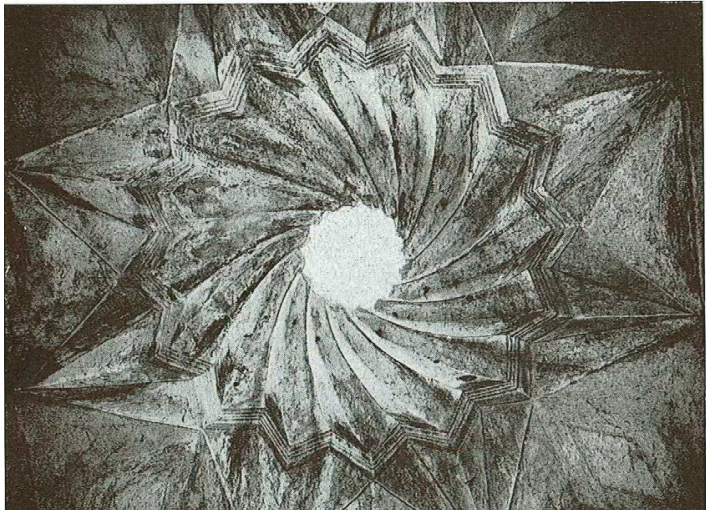

Figure 17a: Edirne Yeniçeri Hamamı Kubbe Süslemesi (Kuban, 1976, Şekil 19)

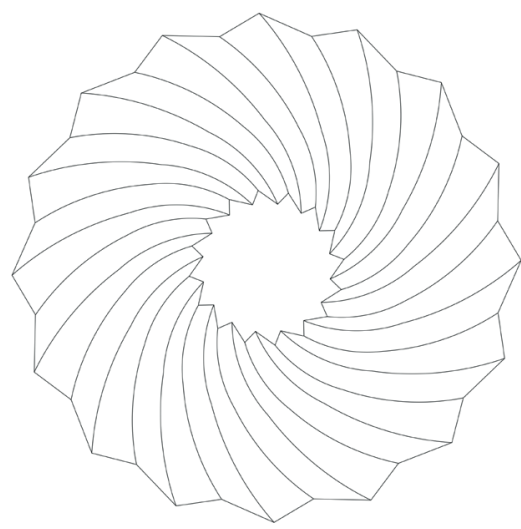

Figure 17b: Edirne Yeniçeri Hamamı Kubbe Süslemesi Çizimi

\section{Mardin Kasımiye Medresesi}

Kitabesi bulunmayan yapıyı adından hareketle Akkoyunlu devletinden Cihangir'in oğlu Sultan Kasım'ın 1487-1502 yılları arasında yaptırmış olabileceği ifade edilmektedir ${ }^{57}$. Açık avlulu, çift katlı, tek eyvanlı planda inşa edilen medrese, cami ve türbe ile beraber yapılmıştır. Medresenin güney cephesindeki kapının arkasında "L" şeklinde bir koridor yer almaktadır ${ }^{58}$. Tonoz örtülü bu koridorun köșesindeki kare alan içte çarkıfelekli dışta dilimli bir kubbe ile kapatılmıştır. Kubbe, sivri yivlerle oluşturulmuş birbirine eş yirmi iki kollu çarkıfelek süsleme ile bezenmiş̧tir. Çarkıfelek, kubbe göbeğindeki dairesel madalyondan başlayarak kubbe eteğine kadar uzanmaktadır. Kollar merkezden eteğe doğru genişlemektedir. Kolların arasında dört sıra halinde zikzak silmeler uzanmaktadır. Böylece kubbe içerisinde birbirini kapsayan beş sıra halinde yirmi iki köşeli yıldız dizileri ile karşılaşılmaktadır (F.18a, F.18b). 


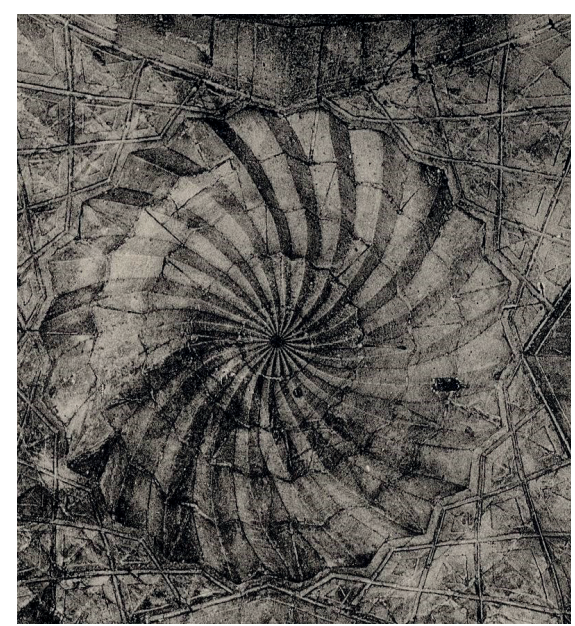

Figure 18a: Mardin Kasımiye Medresesi Kubbe Süslemesi (Gabriel, 1940, Levha 19)

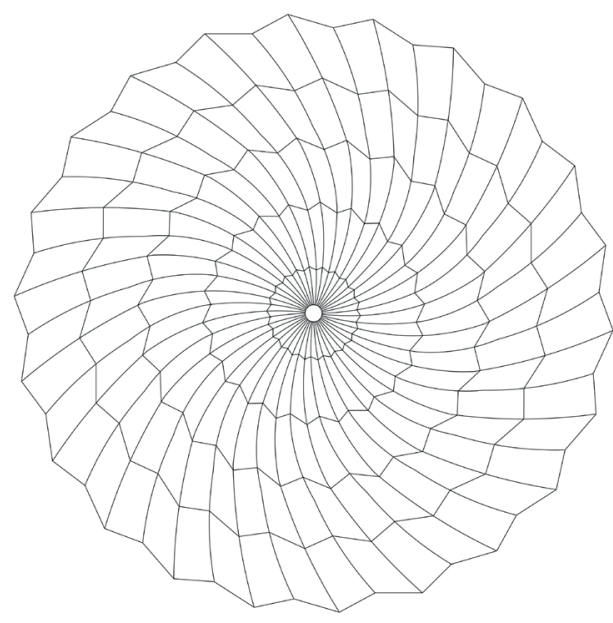

Figure 18b: Mardin Kasımiye Medresesi Kubbe Süslemesi Çizimi

\section{9. İstanbul Mahmut Paşa Hamamı}

İstanbul'un en eski hamamlarından Mahmut Paşa Hamamı, Fatih Sultan Mehmed'in sadrazamlarından biri olan Mahmud Paşa tarafından 1466-67 yılları arasında külliyenin parçası olarak yapılmıştır. Çifte hamam olarak inşa edilen yapı İstanbul'un en eski hamamlarından biridir $^{59}$. Kadınlar bölümü günümüze gelememiş, erkekler bölümü ise iş merkezi olarak kullanılmaktadır. Yıldızvari sıcaklıklı hamamın kuzey ve güney yönlerine halvetler yerleştirilmiştir. Hamamın "T" planlı 1lıklk bölümünün merkezi çarkıfelek süslemeli bir kubbe ile örtülmüştür. Çarkıfeleğin kolları dört sıra halinde yerleştirilmiş filgözleri ile meydana getirilmiştir. Kıvrımlı bir şekilde konumlandırılan filgözleri ile yapılmış on altı kol görülmektedir. Kubbenin göbeğindeki aydınlık fenerinde ortada büyük, kenarlarda altı küçük filgözü pencere mevcuttur (F.19a, F.19b). 


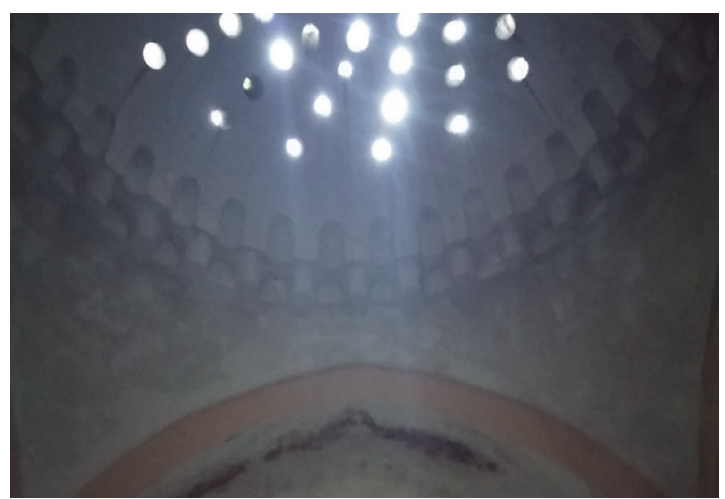

Figure 19a: İstanbul Mahmut Paşa Hamamı Kubbe Süslemesi (İlknur Güler, 2017)

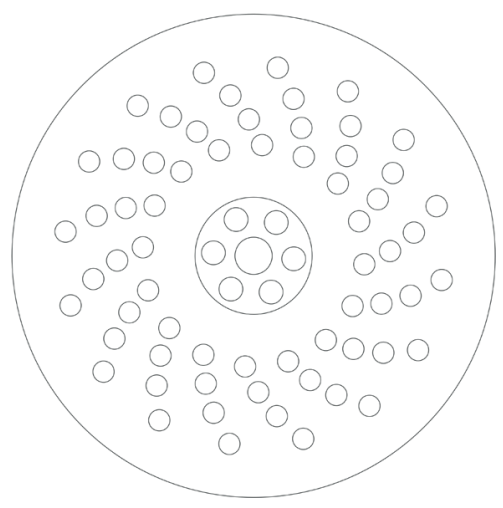

Figure 19b: İstanbul Mahmut Paşa Hamamı Kubbe Süslemesi

Çizimi

\section{Edirne II. Bayezid Camisi}

Sultan II. Bayezid tarafından 1484-88 yıllarında külliyenin bir parçası olarak inşa ettirilmiştir. Cami tabhaneli plandadır. Kare harimin iki yanına bitişik birer tabhane yerleştirilmiştir. Caminin kuzeyinde dört tarafi kubbeli revaklarla çevrelenen avlu yer almaktadır. Son cemaat yeri revakların devamı şeklinde avluya dahil edilmiştir ${ }^{60}$. Beş gözlü son cemaat yerinin ortasında yer alan birimin üzeri diğerlerinden daha yüksek tutulmuş bir kubbe ile örtülmüştür. Pandantif geçişli kubbenin karnı çarkıfelek süsleme ile bezenmiştir. Kubbe göbeğindeki sarkıttan başlayarak eteklere doğru kıvrılan dolu-boş otuz iki kolu bulunmaktadır. Çarkıfeleleğin kolları dalgalı bir şekilde sonlanmaktadır. Kolların konturları siyah kalemişi ile belirginleştirilmiş birer atlamalı olarak içleri maviye ve beyaza boyanmıştır (F.20a, F.20b).

60 Semavi Eyice, "Bayezıt II Cami ve Külliyesi”, DİA, 6, İstanbul, 1992, s. 42-43. 


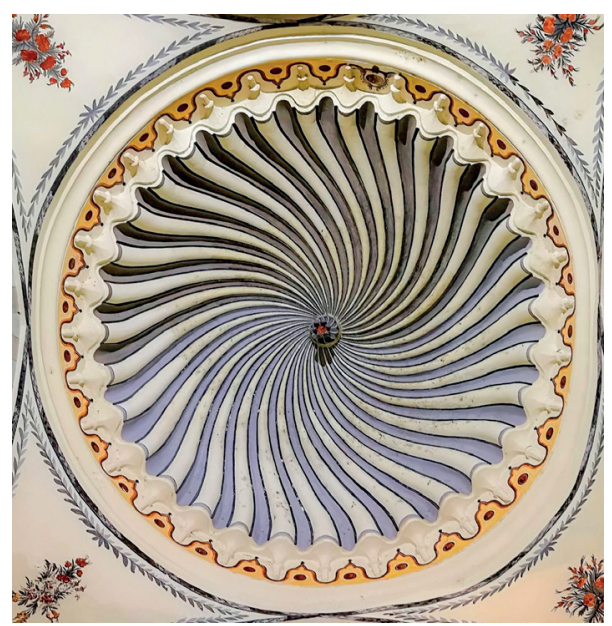

Figure 20a: Edirne II. Bayezid Camisi Kubbe Süslemesi (Alper Altın, 2019)

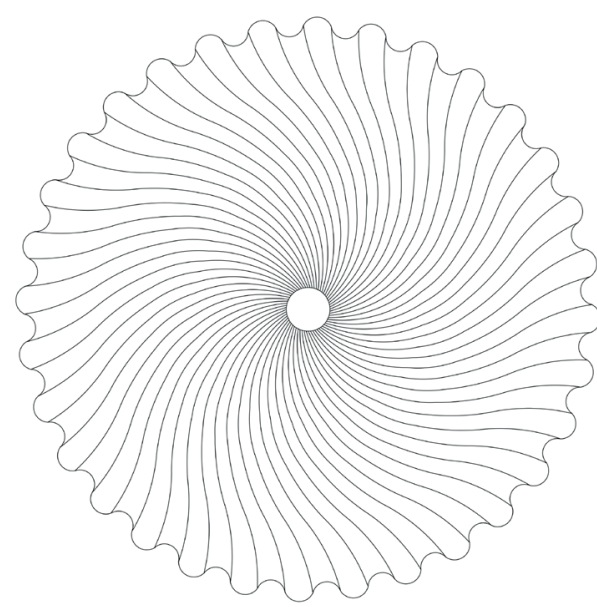

Figure 20b: Edirne II. Bayezid Camisi Kubbe Süslemesi Çizimi

\section{Köstendil Fatih Camisi}

Bulgaristan'ın Köstendil şehrinde yer alan caminin Fatih ismi ile bilinmesine rağmen Kanuni Sultan Süleyman devrinde 1530-31 yıllarında inşa ettirildiği belirtilmektedir ${ }^{61}$. Küçük ölçekte, kare planlı ve kubbe ile örtülü harime sahip caminin kuzeyinde üç gözlü bir son cemaat yeri mevcuttur. Son cemaat yerinde batı kenardaki birimin üzeri mukarnaslı pandantif geçişli kubbe ile örtülmüştür. Kubbenin karnında çarkıfelek bezeme görülmektedir. Çarkıfelek, kubbenin göbeğinden başlayarak kıvrımlı bir şekilde eteklerine doğru genişleyen birbirine eş takribi kırk dört kola sahiptir (F.21a, F.21b).

61 Ekrem Hakkı Ayverdi, Avrupa'da Osmanlı Mimari Eserleri, C.IV, İstanbul, 2000, s. 65-66. 


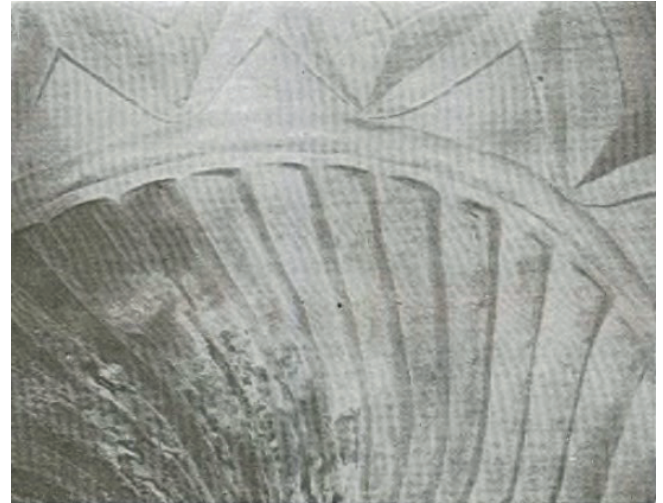

Figure 21a: Bulgaristan Köstendil Fatih Camisi Kubbe Süslemesi (Ayverdi, 2000, Resim 95)

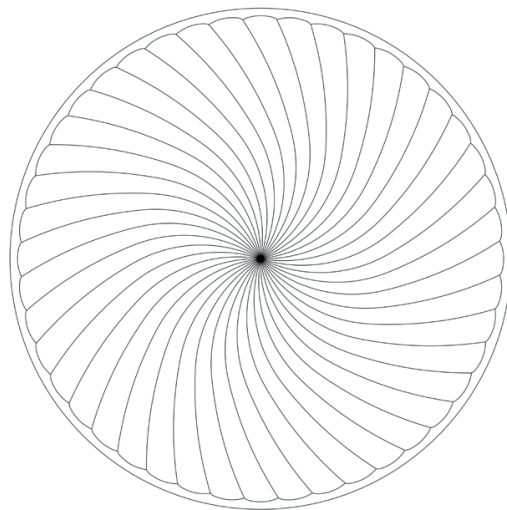

Figure 21b: Bulgaristan Köstendil Fatih Camisi Kubbe Süslemesi Çizimi

\section{Edirne Rüstem Paşa Hanı}

Osmanlı'nın ünlü sadrazamlarından Rüstem Paşa tarafından 1560-61 yılında Mimar Sinan'a yaptırılan yapı şehir içi hanı ve menzilinden müteşekkildir. Han, menzile göre daha büyük bir avluya sahiptir. Avlunun dört kenarında tek sıra revak dizisi yer almaktadır. Handaki dükkanlar revakların arkasına yerleştirilmiştir. Çift katlı hana giriş kuzey cephedeki kapıdan sağlanmaktadır ${ }^{62}$. Girişin hemen üzerinde yer alan doğudan dördüncü mekan içten ve dıştan kubbe ile kapatılmıştır. Mekanın kubbe sırtında çarkıfelek süslemesi dikkat çekmektedir. Kalın nervürlerle yapılan çarkıfelek, kubbenin merkezindeki alemden başlayıp kıvrılarak kubbe eteğine kadar devam etmektedir. Dolu-boş tahmini on iki kola sahip çarkıfelek çokgen kasnakta son bulmaktadır (F.22).

62 N. Çiçek Akçı1, "Rüstem Paşa Kervansarayı”, DİA, 35, İstanbul, 2008, s. 290-291. 


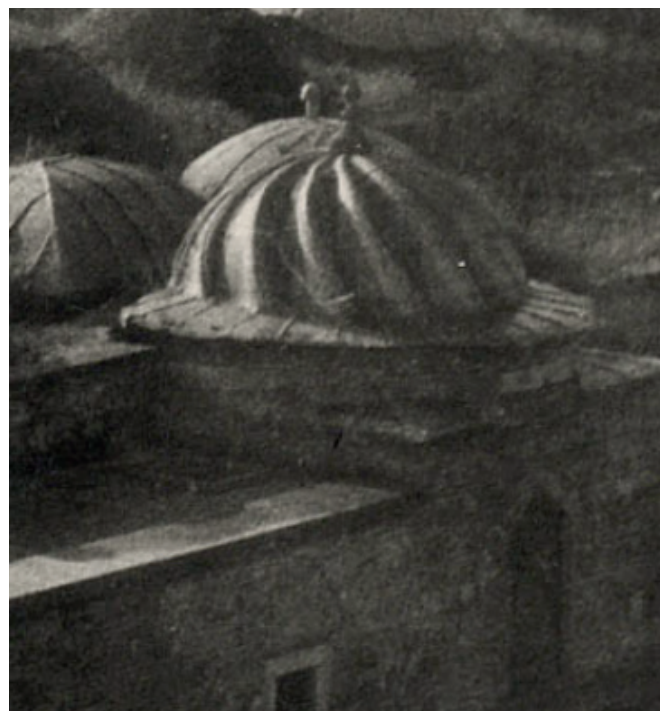

Figure 22: Edirne Rüstem Paşa Kervansarayı Kubbe Süslemesi (Kaynak: https://archives. saltresearch.org/handle/123456789/117228)

\section{Kazvin Ali Kapı Sarayı Kapısı}

Safeviler döneminde 16. yüzyılda Şah Tahmasp tarafından yaptırılan Ali Kapı Sarayı'nın kapısı olarak inşa edilmiştir. Kazvin'de günümüze gelen tek Safevi anıtıdır ${ }^{63}$. Kapının mukarnas kavsaralı eyvanının arkasındaki kare mekanın üzeri yelpaze pandantif geçişli kubbe ile örtülmüştür. Kubbe karnı sırlı ve sırsız tuğlalar kullanılarak çarkıfelek süsleme ile bezenmiştir. Kıvrımlı dolu-boş on iki kola sahiptir. Lacivert sırlı tuğlalarla yapılan kollar, kubbenin göbeğindeki dairesel madalyondan başlayarak kubbe eteğinde baklava dilimi ile sonlanmaktadır (F.23a, F.23b).

63 Anthony Hutt-Leonard Harrow, Islamic Architecture Iran, C.2, Ipswich, 1978, s. 73. 


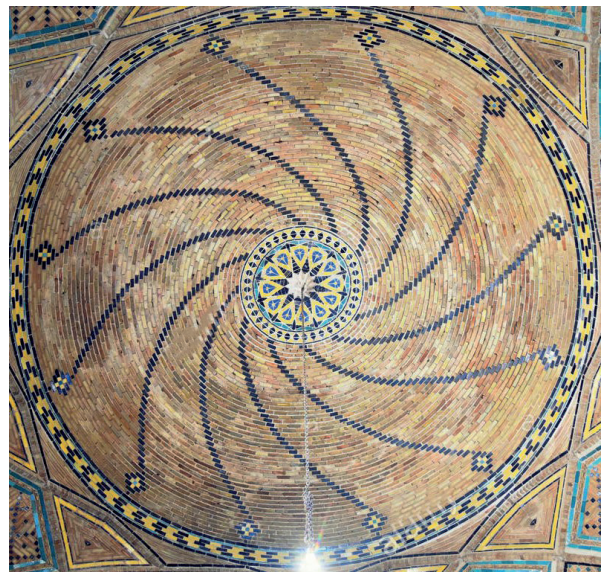

Figure 23a: İran Kazvin Ali Kap1 Sarayı Kapısının Kubbe Süslemesi (Kaynak: https://www.alamy.com/ islamic-architecture-spiral-domedecoration-on-silk-road-era-ali-qapugate-in-qazvin-iranimage 211296905.html)

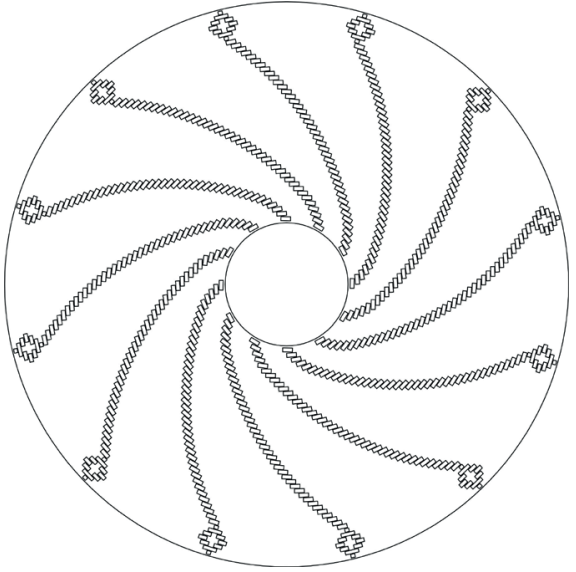

Figure 23b: İran Kazvin Ali Kap1 Sarayı Kapısının Kubbe Süslemesi Çizimi

\section{Maranjab Kervansarayı}

Kum-İsfahan yolu güzergahında yer alan kervansaray Safevi döneminde I. Şah Abbas zamanında 1603 yılında inşa ettirilmiştir. Yapı, açık avlulu dört eyvanlı bir plana sahiptir ${ }^{64}$. Kervansarayda girişin hemen arkasındaki kare mekanın üzeri büyük bir kubbe ile kapatılmıştır. Yelpaze pandantif geçişli kubbede çarkıfelek bezeme görülmektedir. Çarkıfelek süsleme kubbenin karnında sırlı ve sırsız tuğla kullanılarak yapılmıştır. Bir sıra firuze renkli, bir sıra lacivert renkli sırlı tuğlalar almaşık olarak dizilmiştir. Dolu-boş yirmi kola sahip çarkıfelek bezeme kubbenin göbeğindeki aydınlık fenerinden başlamakta, kıvrımlı bir şekilde ilerleyerek kubbe eteğinde haçvari şekille nihayetlenmektedir (F.24a, F.24b). Aydınlık fenerinin üzerindeki kubbede de çarkıfelek süsleme yer almaktadır. Burada ana kubbedekine benzer biçimde altı kollu çarkıfelek bulunmaktadır (F.24c). 


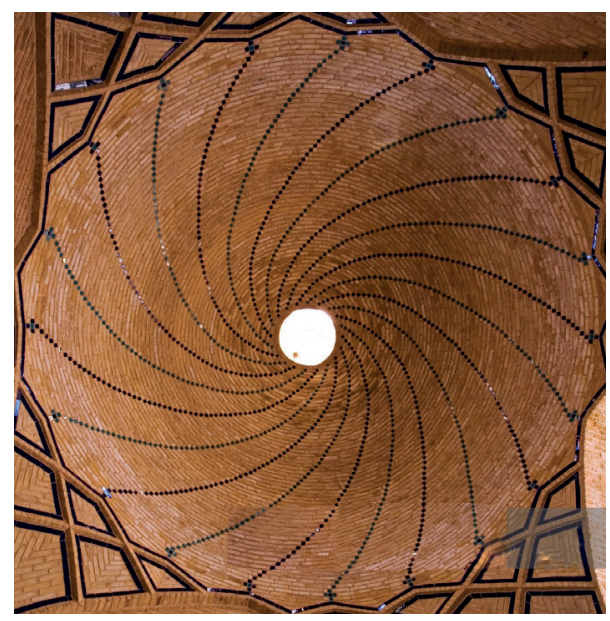

Figure 24a: İran Maranjab Kervansarayı Kubbe Süslemesi (Kaynak:https://www.gettyimages. com/detail/photo/persian-architectureroyalty-free-image/504831107)

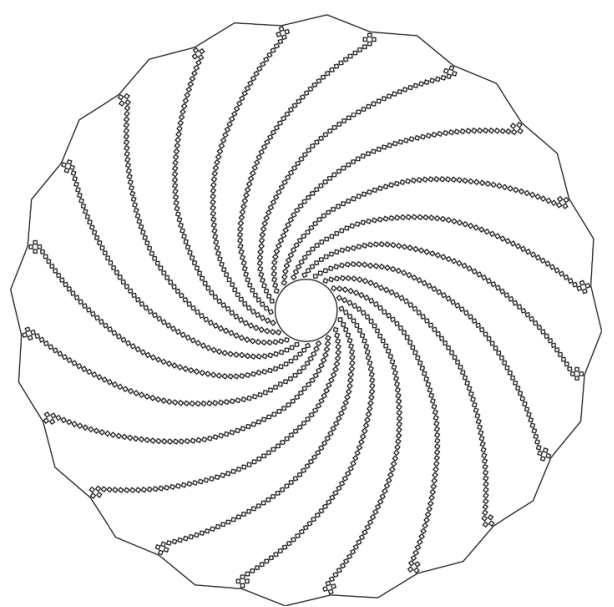

Figure 24b: İran Maranjab Kervansarayı Kubbe Süslemesi Çizimi

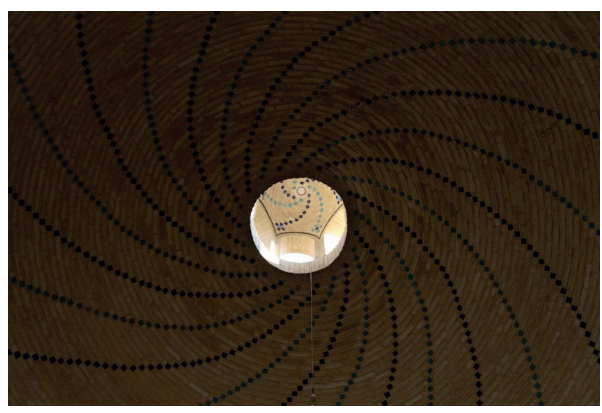

Figure 24c: İran Maranjab Kervansarayı Aydınlık Feneri Kubbe Süslemesi (Kaynak: https://www. gettyimages.com/detail/photo/ persian-architecture-royalty-freeimage/505596149)

\section{Kașan Nușabad Ali Mescidi}

Büyük Selçuklu döneminde inşa edilen caminin sadece minaresi özgün olarak kalmış diğer kısımları sonraki dönemlerde yenilenmiş veya eklenmiştir ${ }^{65}$. Caminin bugünkü planı ve süslemeleri Kaçar döneminden kalmadır. Camide iki farklı çarkıfelek süslemeli kubbe ile karşılaşılmaktadır. Çarkıfelekler kubbe karnında yer almaktadır. Çarkıfelek süslemeler sırlı ve

65 Eravşar-Karpuz, a.g.e., C.2, s. 122. 
sırsız tuğla ile yapılmıştır. Kubbelerden biri ana eyvanda bulunmaktadır. On iki kollu yapılan çarkıfelek firuze renkli sırlı tuğla ile meydana getirilmiştir. Kubbe göbeğindeki madalyondan başlayarak kubbe eteğindeki zikzak dizisinde sonlanmaktadır (F.25a, F.25b). İkinci çarkıfelek süslemeli kubbe giriş eyvanındadır. Münavebeli olarak bir lacivert bir firuze renkli sırlı tuğla ile yapılmış altı kola sahiptir. Kollar kubbe göbeğindeki madalyondan başlamakta, kubbe eteğindeki baklava dilimlerinde sonlanmaktadır (F.25c, F.25d).

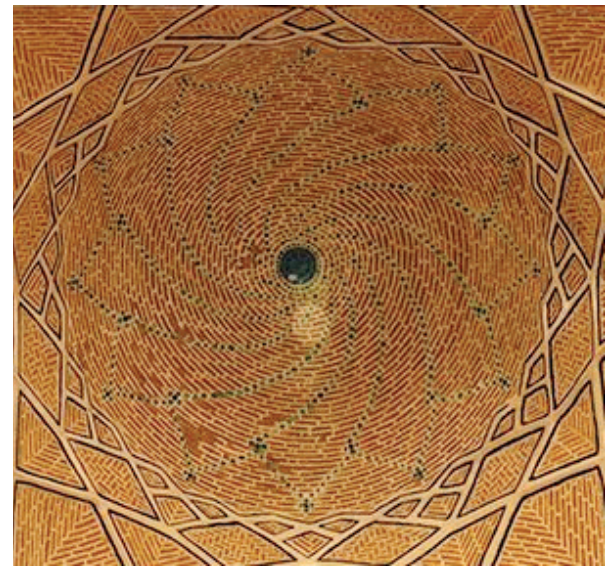

Figure 25a: İran Nuşabad Ali Mescidi Kubbe Süslemesi (Kaynak: https:// www.twenty20.com/photos/ 45bbff6c-83bf-4353-a46b$8 \mathrm{~b} 57 \mathrm{f} 671 \mathrm{e} 077$ )

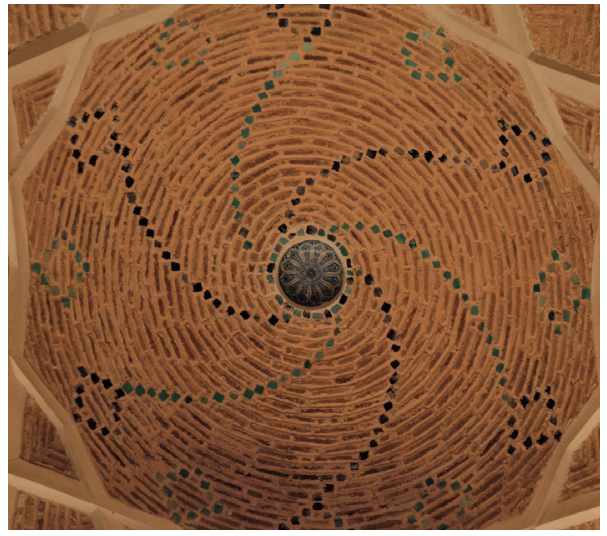

Figure 25c: İran Nuşabad Ali Mescidi Kubbe Süslemesi (Kaynak: http://www. selcuklumirasi.com/architecture-detail/ ali-mescidi-nusabad)

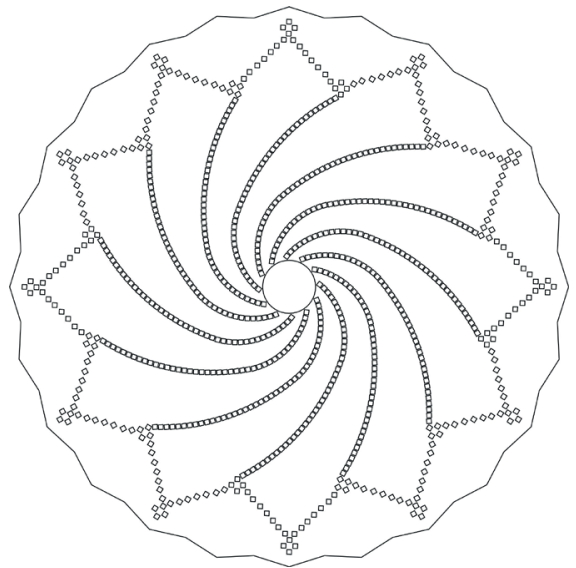

Figure 25b: İran Nuşabad Ali Mescidi Kubbe Süslemesi Çizimi

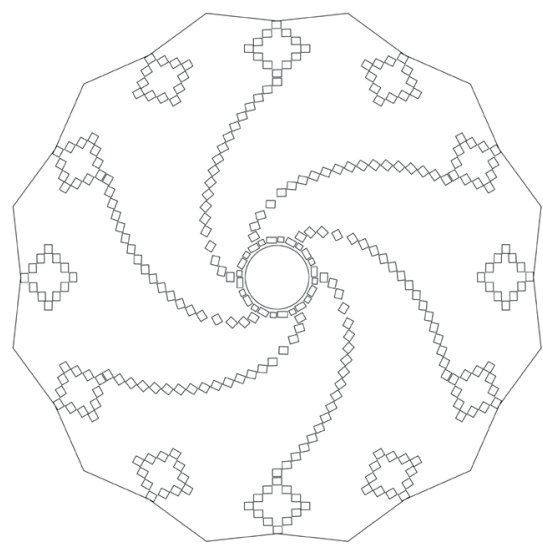

Figure 25d: İran Nuşabad Ali Mescidi Kubbe Süslemesi Çizimi 


\section{Kaşan Sultan Amir Ahmed Türbesi}

Aslen Selçuklu dönemine ait olduğu düşünülen türbe kitabesine göre Safevi döneminde onarım geçirmiştir. Günümüzdeki haliyle Kaçar döneminden kalma türbe, bir tarafta giriş kemeri diğer tarafta büyük bir eyvan bulunan bir avludan oluşmaktadır. Türbe içten kubbe, dıştan konik külahla kapatılmıştır ${ }^{66}$. Çarkıfelek süslemeli kubbe, türbenin giriş eyvanında yer almaktadır. Dikdörtgen eyvan kalın bir kemerle kareye dönüştürülmüş, kare alan nervürlü yelpaze pandantif geçişli kubbe ile kapatılmıştır. Kubbenin göbeğinde oldukça geniş tutulmuş kalemişi madalyon yer almaktadır. Bu madalyondan başlayarak kubbe eteğinde nihayetlenen dolu-boş on dört kola sahip çarkıfelek bezeme yer almaktadır. Sırlı ve sırsız tuğla ile yapılan çarkıfelek süslemede kollar firuze renkli sırlı tuğlalar ile meydana getirilmiştir (F.26a, F.26b).

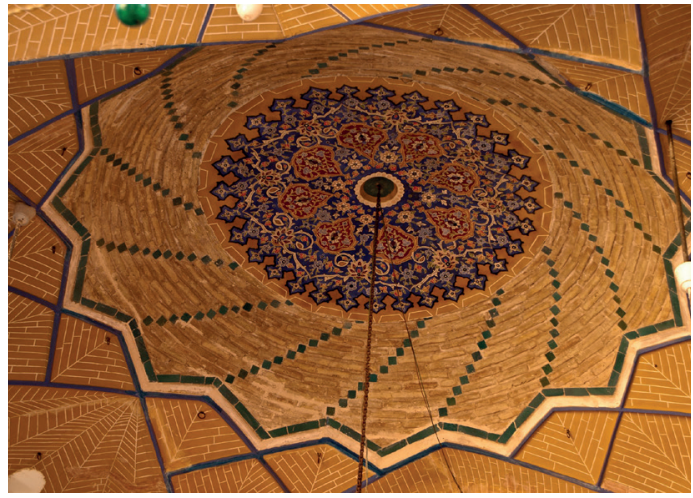

Figure 26a: İran Kaşan Sultan Amir Ahmed Türbesi Kubbe Süslemesi (Kaynak: https://www.flickr.com/photos/ gballardice/7507162420/in/photostream/)

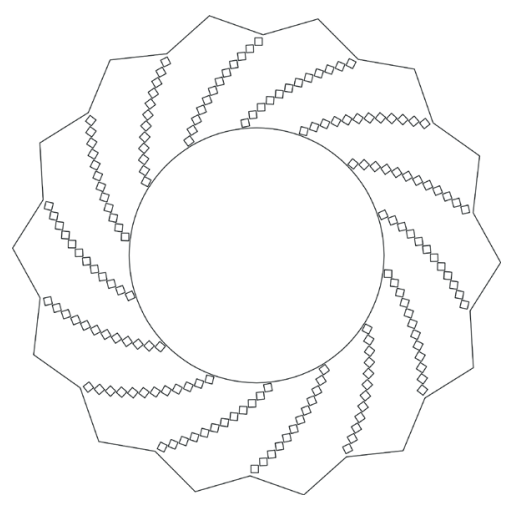

Figure 26b: İran Kaşan Sultan Amir Ahmed Türbesi Kubbe Süslemesi Çizimi

\section{Kaşan Sultan Amir Ahmed Hamamı}

Hamam 16. yüzyılda Safevi döneminde inşa edilmiş, 1778 yılında meydana gelen depremde zarar görmesi neticesinde Kaçar döneminde 18. yüzyılda yenilenmiştir. Geleneksel İran hamamları planında ve büyük boyutlu bir yapıdır ${ }^{67}$. Çarkıfelek süslemeli kubbe hamamın sıcaklık bölümünde bulunmaktadır. Nervürlü yelpaze pandantif geçişli kubbenin kasnağı yıldızvari bir görünüme sahiptir. Kubbenin karnındaki çarkıfelek bezeme sırlı ve sırsız tuğla ile yapılmıştır. On iki kollu çarkıfelek bezeme dolu-boş biçimde kıvrımlı kollara sahiptir. Kollar kubbe göbeğindeki aydınlık fenerinden başlayarak kubbe eteğinde son bulmaktadır (F.27a, F.27b).

66 https://archnet.org/sites/18620 Erişim Tarihi: 01.12.2020

67 https:/www.islamichistoryandtravel.com/sultan-amir-ahmad-hammam-bath-house-kashan/ Erişim Tarihi: 16.11.2020 


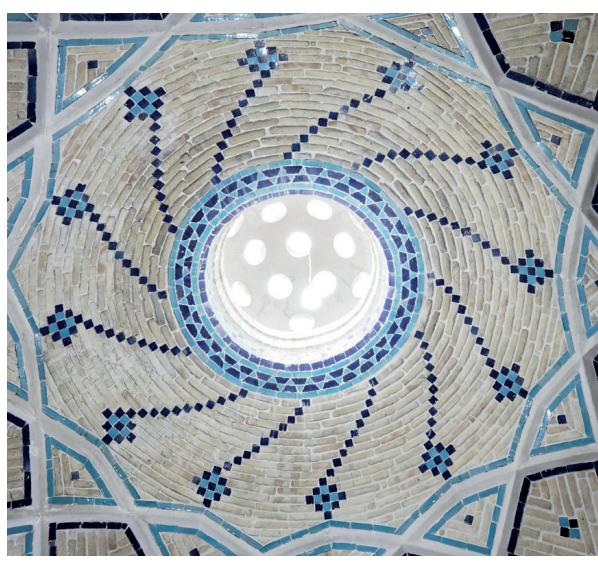

Figure 27a: İran Kaşan Sultan Amir Ahmed Hamamı Kubbe Süslemesi (Kaynak: https://tr.depositphotos. com/211810162/stock-photo-kashaniran-october-2017-brick.html)

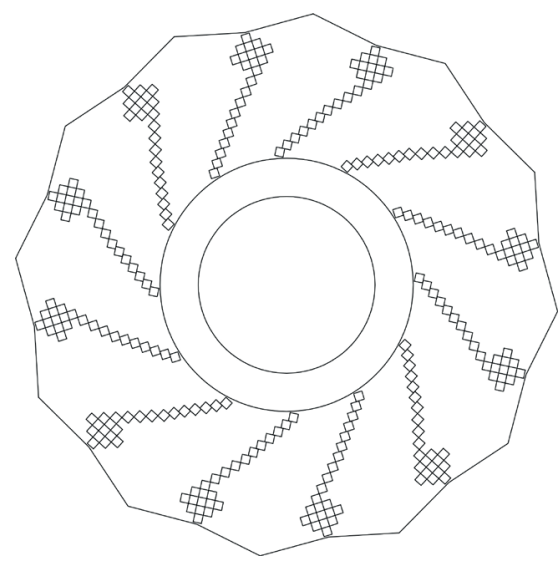

Figure 27b: İran Kaşan Sultan Amir Ahmed Hamamı Kubbe Süslemesi Çizimi

\section{Hokand Medar Han Türbesi}

Hokand Hanlığı döneminde Ömer Han tarafından 1825 yılında annesi adına yaptırılmıştır. Medar han "hanın annesi”" anlamına gelmektedir ${ }^{68}$. Dikdörtgen planlı türbenin iki kenarında uzun kulelerin olduğu anıtsal bir taçkapısı vardır. Türbe silindirik kasnak üzerinde çift cidarlı bir kubbe ile örtülmüştür. Kubbenin karnında çarkıfelek bezeme görülmektedir. Dolu-boş yirmi beş kolla yapılan çarkıfelek, kubbe göbeğinden eteklere kadar uzanmaktadır. Alçı ile yapılan kubbenin içerisi altın yaldız ve firuze renkte boyanmıştır (F.28a, F.28b). Kolların arasındaki satıh bitkisel süslemelerle bezenmiştir.

68 Mayhew Macleod, Decouverte Ouzbekistan Samarcande, Boukhara, Khiva, Cenevre, 2019, s. 136. 


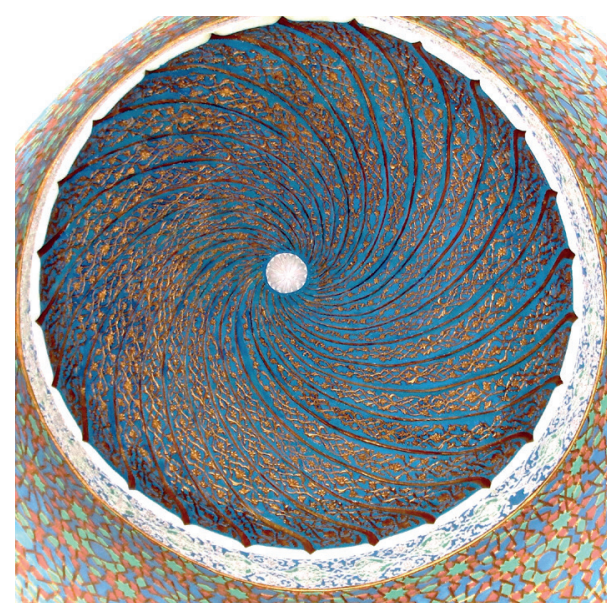

Figure 28a: Özbekistan Hokand Medar Han Türbesi Kubbe Süslemesi (Kaynak: https://www.manzaratourism. com/uzbekistan/modari- khanmausoleum-kokand\#pictures)

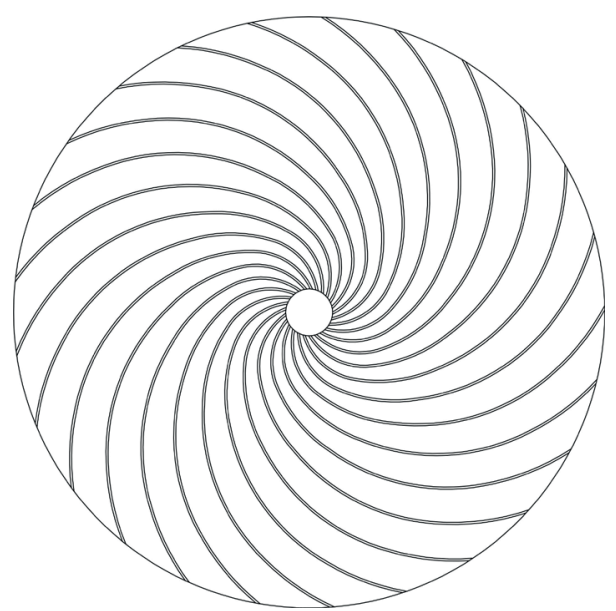

Figure 28b: Özbekistan Hokand Medar Han Türbesi Kubbe Süslemesi Çizimi

\section{Kaşan Ağa Bozork Camisi}

Cami ve medreseden oluşan külliye halinde yapılmış yapı Kaçar döneminde Mirza Taki Han zamanında 1834-49 yıllarında inşa edilmiştir. Külliyenin medresesi Ağa Bozork olarak bilinen Molla Muhammad Mehdi Naraki için yapıldığından dolayı külliye bu isimle anılmıştır ${ }^{69}$. Açık avlulu, merkezi mekanlı dört eyvanlı plan tipindeki camide çarkıfelek süslemeli kubbe güney eyvanın yanındaki kubbeli birimde karşımıza çıkmaktadır. Dolu-boş olarak sekiz kollu yapılan çarkıfelek kubbenin merkezindeki madalyondan başlamakta ve sekiz köşeli yıldızın eşkenar dörtgen köşelerinde sonlanmaktadır. Sırlı ve sırsız tuğla kubbedeki kollar, kare formlu ve patlıcan moru sırlı tuğlalar ile oluşturulmuştur (F.29a, F.29b). Yapıda bundan başka çarkıfelek süslemeli kubbeler de mevcuttur.

69 Beheshti, a.g.e., s. 180. 


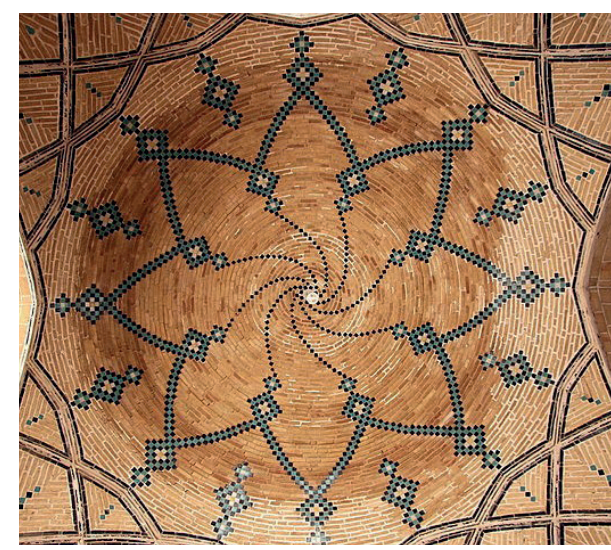

Figure 29a: İran Kaşhan Ağa Bozork Camisi Kubbe Süslemesi (Kaynak: https://commons.wikimedia.org/wiki/ File: Ceiling_inside_Agha_Bozorg_ Mosque_in_Kashan, Iran.JPG)

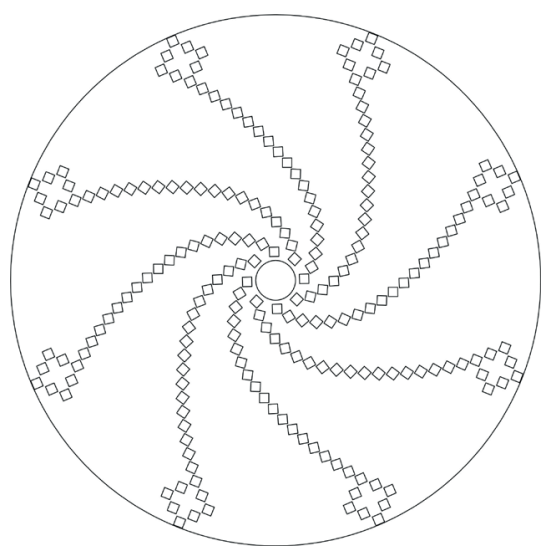

Figure 29b: İran Kaşhan Ağa Bozork Camisi Kubbe Süslemesi Çizimi

\section{Kazvin Şehzade Hüseyin Türbesi}

İmam Rıza'nın oğlu Hüseyin, yolculuk esnasında Kazvin şehrinde vefat etmiş ve orada defnedilmiştir. Buraya Safeviler döneminde çok sayıda yapı inşa edilmiş ve türbe haline getirilmiştir $^{70}$. Yapı 19. yüzyılda Kaçarlar döneminde neredeyse tamamen yenilenmiş̧iir ${ }^{71}$. Kuzey girişinin üzerinde tamamen sırlı tuğlalarla yapılmış kubbe bizi karşılamaktadır. Kubbeye geçiş damarlı yelpaze pandantifle sağlanmıştır. Kubbe karnında merkezdeki madalyondan başlayarak eteklere kadar uzanan çarkıfelek süsleme dikkat çekmektedir. Çarkıfelek birbirine eş on altı kola sahiptir. Ancak kollarda dönüşümlü olarak siyah, beyaz, firuze ve sarı renk olmak üzere dört ayrı renk kullanılmıştır. Bundan dolayı her bir renkte verilen dört kıvrımlı kola sahip olduğu belirtilebilir (F.30a, F.30b).

70 Muhammed Yusuf Keyani, İslam Dönemi İran Mimarisi, Ankara, 2018, s. 114

71 Hutt-Harrow, a.g.e., s. 156. 


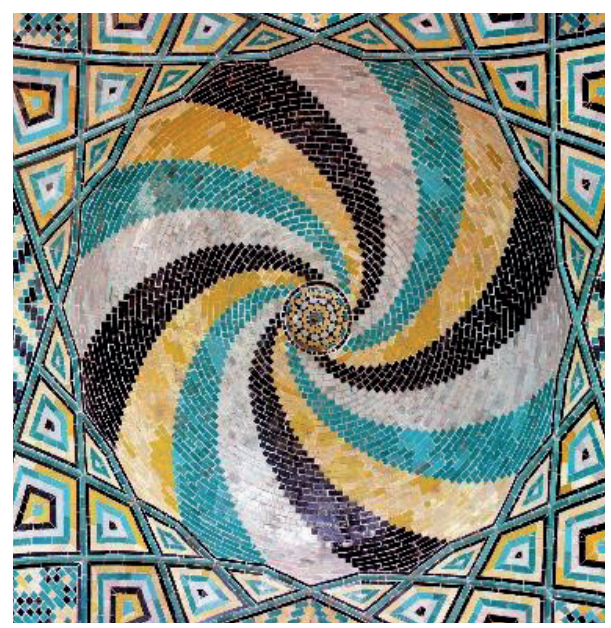

Figure 30a: Kazvin Şehzade Hüseyin Türbesi Kubbe Süslemesi (Kaynak: https://www.tripadvisor.com/ LocationPhotoDirectLink-g680026d12229976-i310607852-Imamzadeh Shahzadeh_Hossein-Qazvin_Qazvin_ Province.html)

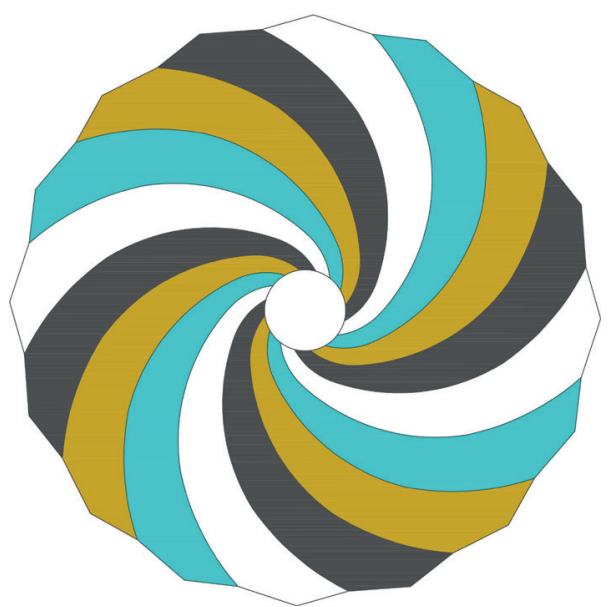

Figure 30b: Kazvin Şehzade Hüseyin Türbesi Kubbe Süslemesi Çizimi

\section{Gülpayegan Cuma Camisi}

Büyük Selçuklu sultanı Muhammed Tapar döneminde 12. yüzyılda inşa ettirilen cami, Safevi ve Kaçar dönemlerindeki ekleme ve yenilemelerle bugünkü halini almıştır. Son büyük onarım 19. yüzyılda gerçekleşmiştir ${ }^{72}$. Caminin doğu eyvanında yer alan çarkıfelek bezemeli kubbe dolu-boş on iki kola sahiptir. Kollar firuze renkli sırlı tuğla ile yapılmıştır. Kollar kubbe göbeğindeki dairesel madalyondan başlayıp kıvrılarak kubbe eteğinde sonlanmaktadır. Kubbe eteğinde kolların arasında haçvari süslemeler yer almaktadır (F.31a, F.31b).

72 Eravşar-Karpuz, a.g.e., C.1, s. 356-357. 


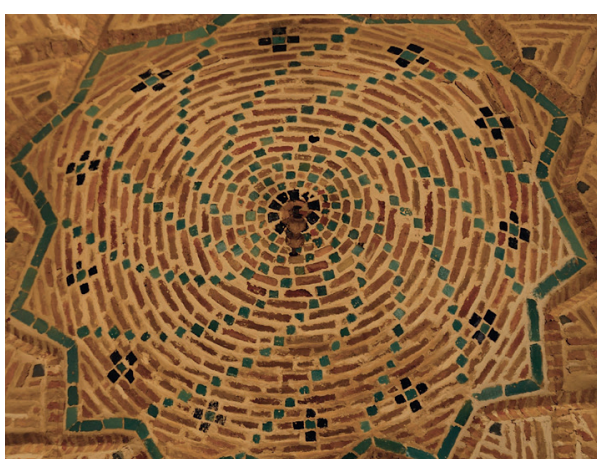

Figure 31a: İran Gülpayegan Cuma Camisi Kubbe Süslemesi (Kaynak: http://www.selcuklumirasi.com/ architecture-detail/gulpayegancuma-camii)

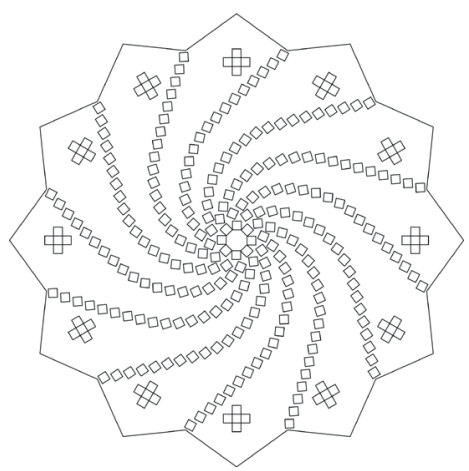

Figure 31b: İran Gülpayegan Cuma Camisi Kubbe Süslemesi Çizimi

\section{Kazvin Sa'd al-Saltaneh Kervansarayı}

Kaçar döneminde yapılan kervansarayı Sa'd al-Saltaneh Isfahani adında bir kişi inşa ettirmiş̧ir. İran'ın en iyi korunmuş kentsel anıtlarından biri olan kervansaray, büyük boyutlu bir yapıdır. Yedi avlu etrafında şekillenmiş kervansaray kapalı çarşı hüviyetindedir ${ }^{73}$. Kervansarayın güneyindeki iki sokağın kesiştiği yerde çarkıfelek süslemeli kubbe ile karşılaşılmaktadır. Nervürlü yelpaze pandantif geçişli büyük bir kubbe ile örtülü alan sırlı ve sırsız tuğla kullanılarak bezenmiştir. Çarkıfelek süsleme kubbenin tamamında görülmese de 4/1'lik kısmını kaplamaktadır. Kubbe göbeğindeki aydınlık fenerinden başlayarak dışta yer alan dairesel bordürle sınırlanmaktadır. Dolu-boş on kola sahip çarkıfelek diyagonal kare ile sonlanmaktadır. Kolların arasındaki boş kısımlara bir büyük biri küçük iki diyagonal kare daha yerleştirilmiş̧iir (F.32a, F.32b). Bir başka çarkıfelek süslemeli kubbe kervansaray girişinin hemen önünde yer alan kubbeli mekanda bulunmaktadır. Sırlı ve sırsız tuğla örgü ile yapılan çarkıfelek dolu-boş sekiz kola sahiptir. Kıvrımlı bir şekilde kubbenin aydınlık fenerinden başlayan kollar, kubbe eteğinde baklava dilimi ile nihayetlenmektedir (F.32c, F.32d).

73 https://en.wikipedia.org/wiki/Sa\%27d_al-Saltaneh_Caravanserai Erişim Tarihi: 25.11.2020 


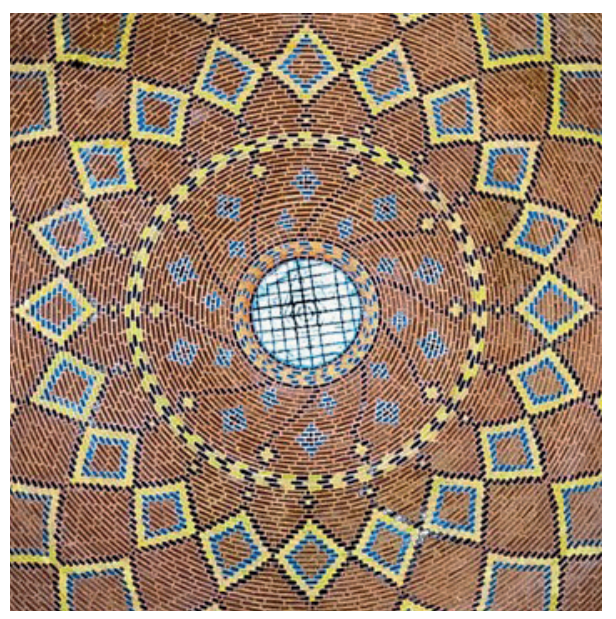

Figure 32a: İran Kazvin Sa'd alSaltaneh Kervansarayı Kubbe Süslemesi (Kaynak: https://commons. wikimedia.org/wiki/File:Caravanserai Of_Sa_D_Al_Saltaneh (186152881).jpeg)

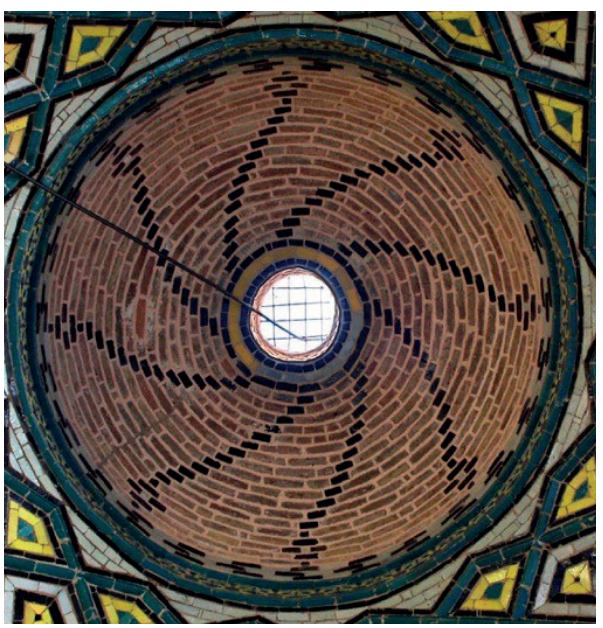

Figure 32c: İran Kazvin Sa'd alSaltaneh Kervansarayı Kubbe Süslemesi (Kaynak: http://www. semerkanddanbosnaya.com/ portfolio/kazvin/)

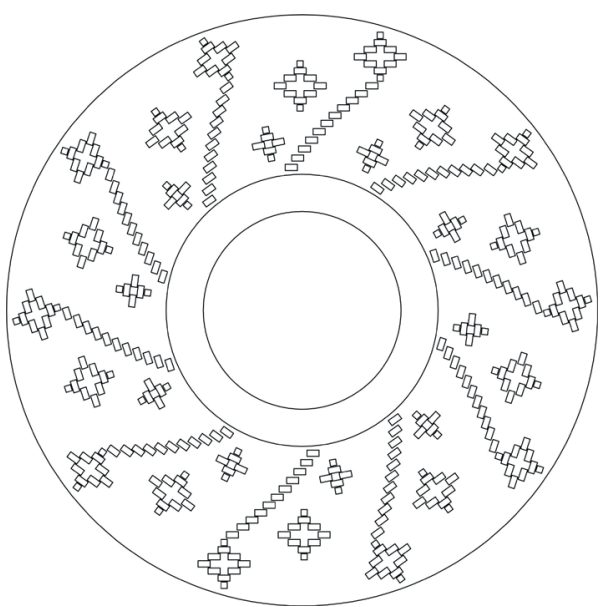

Figure 32b: İran Kazvin Sa'd alSaltaneh Kervansarayı Kubbe Süslemesi Çizimi

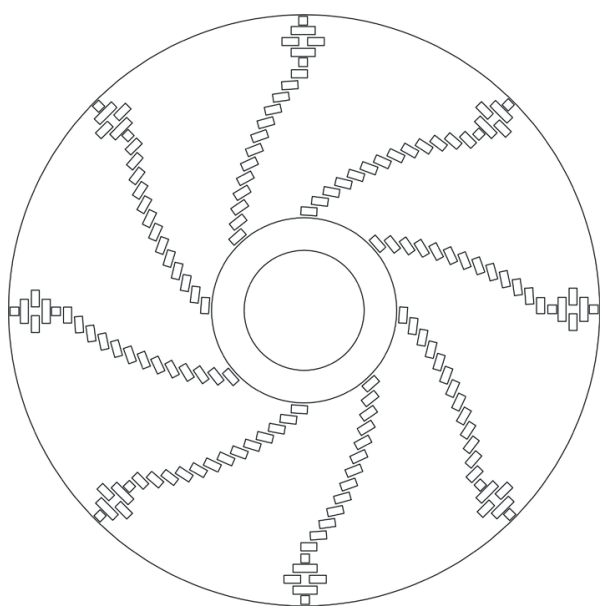

Figure 32d: İran Kazvin Sa'd alSaltaneh Kervansarayı Kubbe Süslemesi Çizimi 


\section{3. Şiraz Nasır'ül-Mülk Camisi}

Şiraz' da 1876-1888 yıllarında Kaçar hanedanından Nasıreddin Şah'ın inşa ettirdiği cami, pembe renkli çinilerinden dolayı pembe cami olarak da anılmaktadır ${ }^{74}$. Cami dikdörtgen bir avlu etrafında yerleşmiş düzensiz bir plana sahiptir. Caminin çarkıfelek süslemeli kubbeleri avlunun doğusundaki mekanlarda yer almaktadır. Kubbelerin yarısını kaplayacak şekilde yapılan çarkıfelek süslemeli kubbelerden biri dolu-boş yirmi dört kola (F.33a, F.33b), Diğeri yirmi iki kola sahiptir (F.33c, F.33d). Sırlı ve sırsız tuğla ile yapılan çarkıfelek bezemeler kubbe göbeğindeki madalyonlardan başlamakta ve kubbenin ortasındaki baklava dilim dizisinde sonlanmaktadır. Camide bunlardan başka çarkıfelek bezemeli kubbelerde mevcuttur.

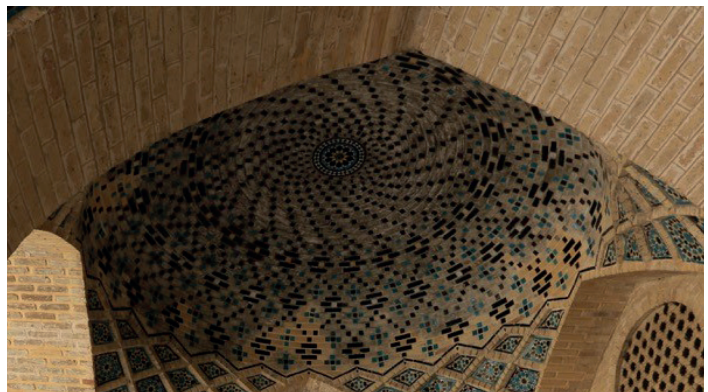

Figure 33a: İran Şiraz Nasır'ül-Mülk Camisi Kubbe Süslemesi (Kaynak:http://www. semerkanddanbosnaya.com/portfolio/nasir-elmulk-camii/)

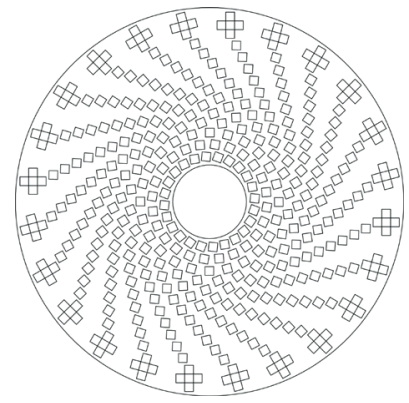

Figure 33b: İran Şiraz Nasır'ül-Mülk Camisi Kubbe Süslemesi Çizimi 


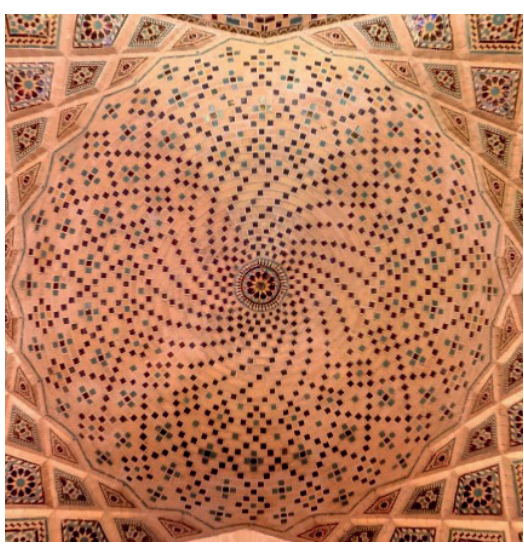

Figure 33c: İran Şiraz Nasır'ülMülk Camisi Kubbe Süslemesi (Kaynak: https://en.wikipedia. org/wiki/Nasir-ol-Molk Mosque\#/media/File:Masdjed-e_ Nasr_ol_molk.jpg)

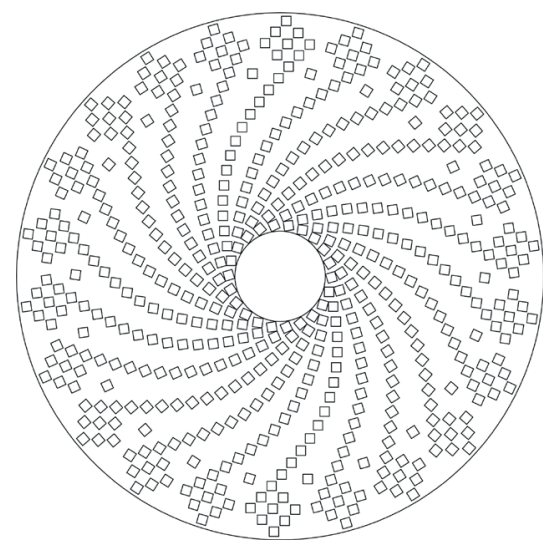

Figure 33d: İran Şiraz Nasır'ülMülk Camisi Kubbe Süslemesi Çizimi

\section{Kazvin Cuma Camisi}

İran'ın en eski camilerinden Kazvin Cuma Camisi'nin geçmişi Abbasi dönemine kadar gitmektedir. Büyük Selçuklu döneminde 11-12. yüzyılda kubbeli kısmı yapılmış, sonraki dönemlerde çeşitli eklemelerle günümüze gelmiştir. Caminin bugünkü süslemelerinin çoğunluğu Kaçarlar döneminden kalmadır ${ }^{75}$. Caminin mihrap önü kubbesinin sırtında çarkıfelek süsleme yer almaktadır. Bu kubbeli alan Büyük Selçuklu döneminde yapılmıştır. Ancak kubbenin dış cidarındaki sırlı tuğla ile meydana getirilen çarkıfelek bezemeli süsleme muhtemelen Safeviler döneminde Şah II. Abbas zamanında güney eyvanı yaptırılırken eklenmiş olmalıdır. Kubbenin dışındaki bu çarkıfelek süsleme firuze renkli sırlı tuğlaların arasında ince şerit halinde yapılan beyaz sırlı tuğlalar ile meydana getirilmiştir. Beyaz sırlı tuğlaların kenarlarına siyah sırlı tuğlalarla kontur yapılmıştır. Kollara baklava dilimleri tutturulmuştur (F.34a). Diğer iki çarkıfelek süsleme caminin doğu eyvanının arkasında bulunan giriş kapısında yer almaktadır. Geçit kısmının üzeri diyagonal olarak yerleştirilmiş üçer sıra halinde dokuz kubbecik ile örtülmüştür. Bu kubbeciklerden köşede konumlandırılmış olanlar çarkıfelek bezemeli yapılmıştır. Dolu-boş on iki kola sahip çarkıfelek kubbe göbeğinden eteğe kadar uzanmaktadır (F.34b, F.34c, F.34d).

75 Eric Schroeder, "The Seljuk Period", A Survey of Persian Art from Prehistoric Times to Present, C.3, New York, 1967, s. 996. 


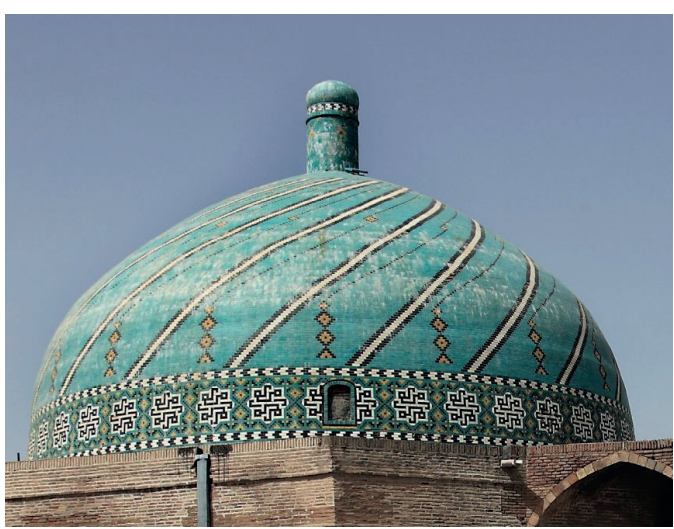

Figure 34a: İran Kazvin Cuma Camisi Kubbe Süslemesi (Kaynak: http://www. selcuklumirasi.com/architecture-detail/ kazvin-cuma-camisi)

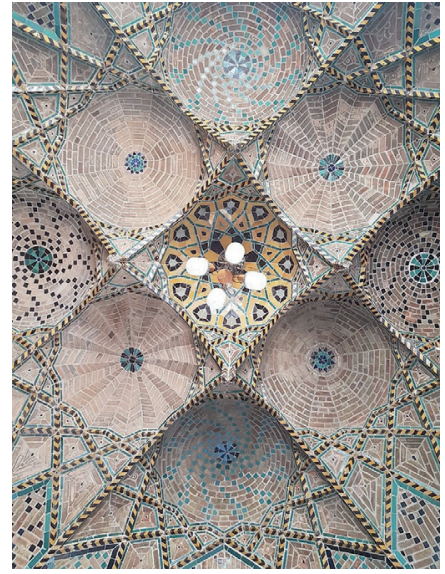

Figure 34b: İran Kazvin Cuma Camisi Kubbecik Süslemesi (Kaynak: https://fa.wikipedia.org/i/\% D9\%85\%D8\%B3\%D8\%AC\%D8\%A F_\%D8\%AC $\%$ D8\%A7\%D9\%85\%D 8\%B9_\%D9\%82\%D8\%B2\%D9\%88 $\% \mathrm{DB} \% 8 \mathrm{C} \% \mathrm{D} 9 \% 86 \# /$ media/\%D9\%B E\%D8\%B1\%D9\%88\%D9\%86\%D8 \%AF\%D9\%87:Qazvin-Jameh.jpg)

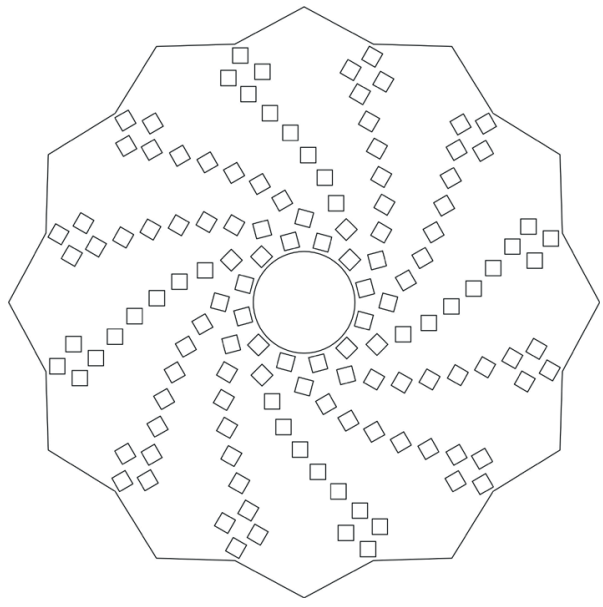

Figure 34c: İran Kazvin Cuma Camisi Kubbecik Süslemesi Çizimi

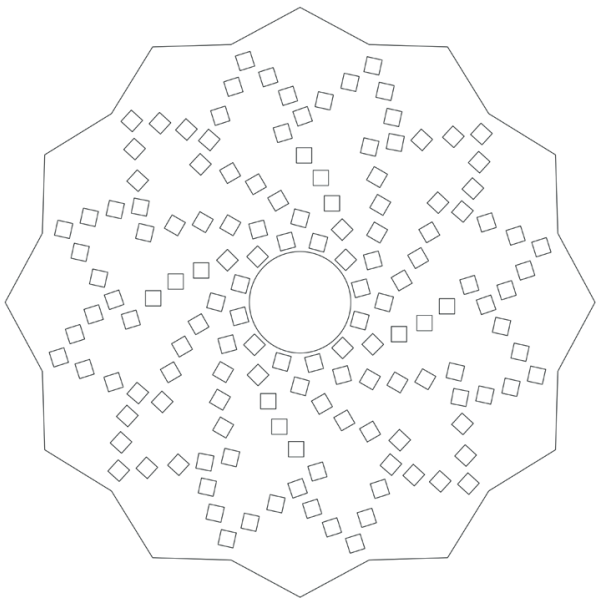

Figure 34d: İran Kazvin Cuma Camisi Kubbecik Süslemesi Çizimi

\section{Değerlendirme ve Sonuç}

Türk-İslam mimari süslemelerinde ve el sanatlarında sıklıkla karşımıza çıkan motiflerden biri olan çarkıfeleğin kubbelerde de bezeme unsuru olarak kullanıldığı görülmektedir. Çarkıfelek 
formlu kubbeler birden çok kavisli kolu ile kubbenin iç veya dış yüzeyini bezemektedir. Bununla birlikte dilimli kubbeler de tıpkı çarkıfelek formlu kubbelerde olduğu gibi kollara sahiptir. Ancak kolları kavisli verilmediği için devinimi yansıtmamaktadır. Bundan dolayı dilimli form ile çarkıfelek formu birbirinden ayrılmaktadır. Çarkıfelek formlu kubbelerin en dikkat çekici unsuru hareketsiz yarım küre biçimli örtü elemanına kattığı harekettir. Türk-İslam mimari eserlerinden kubbesi çarkıfelek formlu bezemeye sahip 39 örnek tespit edilmiştir. Bunlardan dördünün sırtı yani dış kısmı, otuz beşinin ise karnı yani iç kısmı çarkıfelek formlu yapılmıştır. Ağırlıkla kubbelerin karnında yer alması İslam mimari süslemelerinin içe dönük yapılması ile açıklanabilir. Sırt kısmında çarkıfelek süslemesi olan örneklerden ikisinin Kahire'de bulunması Mısır bölgesindeki yapıların kubbelerinin dış kısımlarının süslü olmasından ileri gelmektedir. Aynı şekilde İran' da yer alan süslemenin de bölgedeki kubbelerin dış kısımlarının süslenmesi ile açıklanabilir. Kollar on dört örnekte aydınlık fenerinden, yirmi bir örnekte madalyondan veya alemden, dört örnekte ise doğrudan göbekten çıkmaktadır. Kollar tıpkı eylemsizlik momenti ilkesinde olduğu gibi dengeli bir şekilde dağılmış birbirlerine olan uzaklıklarını, kubbenin büyüklüğü ve kol sayıları belirlemiştir. Kubbelerde kullanılan çarkıfeleklerin kol sayısında bir düzen veya eşitlik yoktur. Her yapının kubbesindeki çarkıfelek süslemenin kolları kendine özgü kıvrım ve kol sayısına sahiptir. Kollar birbirine eş olanlar ve dolu-boş yapılanlar olarak iki farklı düzendedir. Tespit ettiğimiz örnekler içerisinde en az kol sayısı Nuşabad Ali Camisi'ndeki (6 kollu) en çok kol ise Bursa Devlet Hatun Türbesi'ndeki kubbede (48 kollu) mevcuttur. Doluboş şekilde yapılmış kollar birbirine kontrast yapacak şekilde tasarlanmıştır. Bundan dolayı hem dolu hem de boş kolları saydığımızda iki katı kol sayıları karşımıza çıkmaktadır. Bunu göz önüne aldığımızda en çok kol sayısı Malatya Ulu Camisi’ndeki kubbede görülmektedir. Kolların dönüş yönü 26 örnekte saat yönünde iken 13 örnekte saat yönünün tersinedir. Kollar 3 örnek dışında çift sayıda tasarlanmıştır (F.35, F.36).

Türk-İslam mimari eserlerinde yer alan kubbelerde çarkıfelek bezemeli süsleme 34 ayrı yapıda 39 örnekte karşımıza çıkmıştır. Bizim saptayamadığımız veya günümüze gelememiş örneklerin olabileceği düşünülürse bu sayının daha da fazla olabileceği belirtilebilir. Özellikle İran bölgesindeki yapıların detaylı bir envanteri çıkarıldı ̆̆ında, sayının çok daha fazla olacağı kanaatindeyiz. Örneklerden en erken tarihlisi 11-12. yüzyıla kadar gitmektedir. En geç tarihli örnekler ise 19. yüzyıla tarihlenmektedir. Çarkıfelek bezemeli kubbelerden on yedisi İran'da, ikisi Mısır'da, biri Özbekistan'da, biri Bulgaristan'dadır. Geriye kalan kısmı ise Türkiye sınırları içerisinde yer almaktadır. Tespit edilen örnekler kronolojik sırada verilmiştir. İran bölgesi dışındaki çoğu yapının kesin tarihi biliniyorken İran' daki yapıların hakkında az bilgi bulunması, özgün kalmaması, eklentilerin yapılması veya yıkılarak tekrardan inşa edilmesinden dolayı tarihlendirilmeleri problemli olmuştur. Verilen örnekler içerisinde 19'u sırlı ve sırsız tuğla, 13'ü tuğla ve alçı, 5'i taş, 2'si alçı ve kalemişi ile yapılmıştır. Çarkıfelek süslemeli kubbelerden 14'ü camilerde, 11'i hamamlarda, 6'sı türbelerde, 4'ü kervansaraylarda, birer adet de medrese, mescit, saray ve sarnıçta görülmektedir. Hamamların 10’u Türkiye sınırları 
içinde, biri İran'da yer almaktadır. Özellikle Anadolu hamamlarında diğer yapılardan daha fazla bulunması tesadüf değildir. Çünkü hamamların üst örtülerindeki çeşitlilik diğer yapılara nazaran daha fazladır. Aynı hamamda bile mekanların üzerinin farklı biçimdeki üst örtü ile kapatıldığı bilinmektedir ${ }^{76}$. Cami kubbelerinde çarkıfelek süsleme özellikle sırlı ve sırsız tuğla malzemede karşımıza çıkmaktadır. İran bölgesindeki tüm camilerin kubbesindeki çarkıfelek süsleme bu malzeme ile yapılmıştır. Anadolu'daki Malatya Ulu Camisi'nin kubbesindeki çarkıfelek süslemesi hem plan olarak hem de süsleme olarak Büyük Selçuklu geleneğinin devamı olduğunu göstermektedir.

En erken örneğin Türklerin eskiden hüküm sürdüğü İran'da bulunduğunu daha sonra göç ettikleri yerlere de tezyinat anlayışlarını taşıdıklarını görmekteyiz. Mısır'da Bahri Memlukler döneminde kubbe sırtında çarkıfelekli bezeme yapılması rastlantı değildir. Muhtemelen ustaların veya banilerin geldiği coğrafyalardan göz aşinalıkları vardır. Bahri Memlukleri sonrasında Mısır bölgesinde kubbe sırtında süsleme geleneği devam etmesine rağmen çarkıfelek süslemeli benzer örneklerin görülmemesi belirttiğimiz hususu açıklamaktadır ${ }^{77}$. Aynı şekilde Anadolu'da da örneklerin olması kadim gelenekle olan bağın göstergesidir. Anadolu'daki erken tarihli örneklerin İran'daki Kaşhan Sarnıcı'nda olduğu gibi sırlı ve sırsız tuğla örgü ile yapılmış olması bunun açık delilidir. İran'daki gelenek sadece batıya taşınmakla kalmamış bölgede kurulan Türk-İslam devletlerinin yaptırmış olduğu yapılarda da kullanımına devam edilmiştir. Özellikle Kaşhan ve Kazvin bölgesi çevresinde çarkıfelek süslemeli kubbelerin devam ettirilmesi bu geleneğin devamı olarak görülebilir. Türk-İslam mimarisinde İran'da çok fazla örneğin olması Türklerin nüfuz ettiği yeni kültür çevresinin geleneklerinin tamamen etkisi altına girmeyip, kendi kadim kültürleriyle bölgenin kültürünü sentezleyip yenilikçi bir anlayış sergilemesinden kaynaklanmaktadır ${ }^{78}$.

Bir örtü sistemi olarak kubbelerin mekanlarda merkezi belirleme özelliği vardır. Bunu Selçuklu hanlarının kapalı kısımlarının ekseriyetle tam ortasına yapılan kubbelerinden ${ }^{79}$, camilerin mihrap önüne yerleştirilen kubbelerinden, kapalı avlulu medreselerin ortasını örten kubbelerinden veya sarayların taht odalarının üzerinin kubbe ile örtülmesinden anlayabiliriz. Yani kubbe başlı başına bir hakimiyet sembolü olarak örttüğü birimi merkez konumuna getiren bir örtü sistemi olarak düşünülebilir. Bununla birlikte mekanı dışşartlardan koruyan örtü olan kubbeler, göğün sembolü olarak da tasavvur edilmektedir. Gökkubbe kavramı Türkler tarafından kubbenin göğe benzetildiği için oluşturduğu bir kelime olarak karşımıza çıkmaktadır. Kare altyapıdan dairesel üst örtüye geçiş, yerin simgesi olan kareden göğün simgesi olan daireye geçişle açıklanabilir. Özellikle Malatya Ulu Camisi ve Kazvin Cuma Camisi mihrap önü

76 Bkz. Seda Kula Say, Erken Dönem Osmanlı Hamamlarında Eğrisel Örtüye Geçiş Sistemleri, İstanbul Teknik Üniversitesi Fen Bilimleri Enstitüsü Yayınlanmamış Yüksek Lisans Tezi, İstanbul, 2007, s. 356-357.

77 Cipriani, a.g.e., s. 31.

78 Ali Uzay Peker, “Türklerin Evrensel Hükümdarlığının İran'da Sanat ve Mimariye Getirdiği Açılımlar”, Denge Dergisi, S.1, Ankara, 2016, s. 49.

79 Ögel, a.g.e., s. 78. 


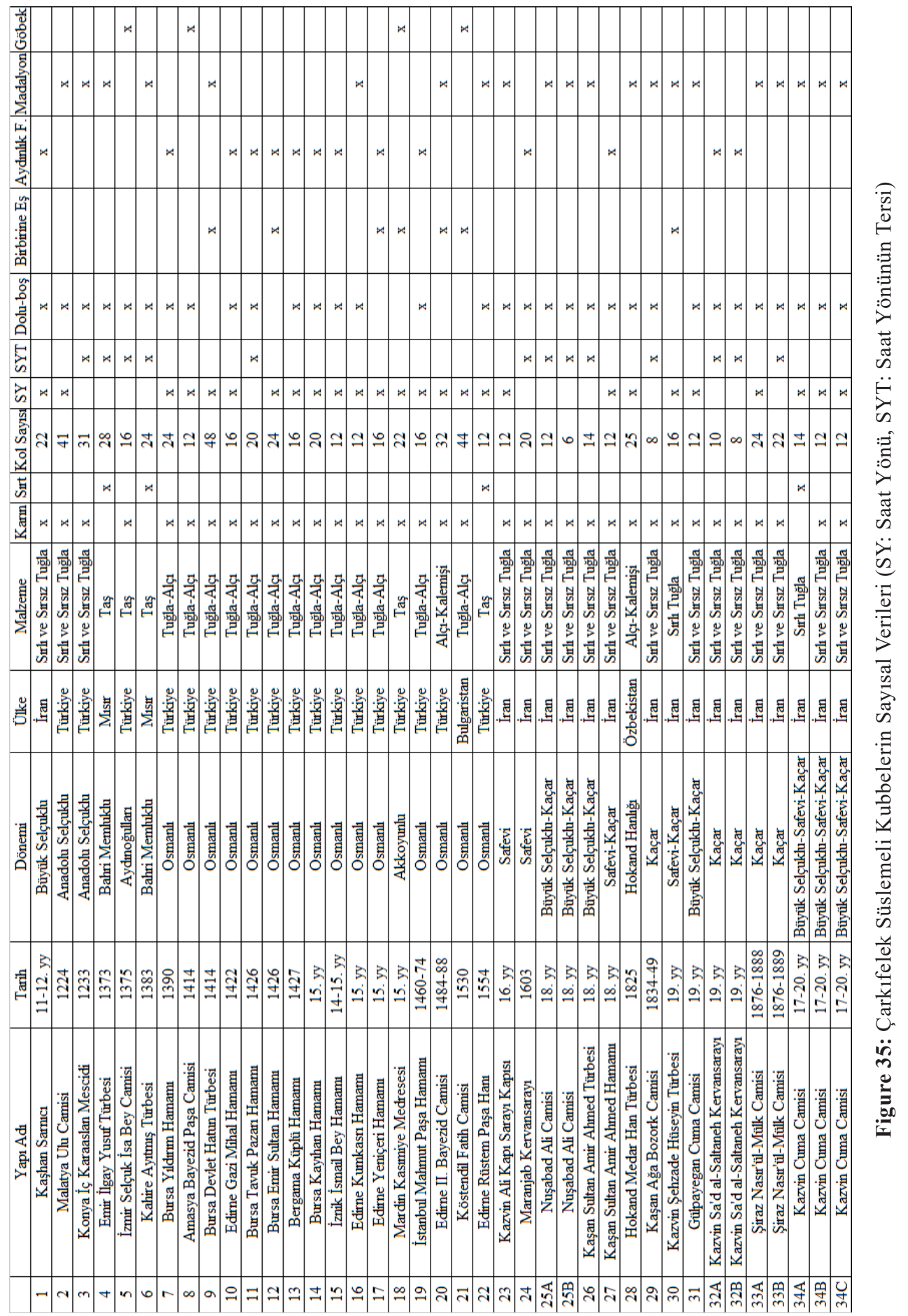



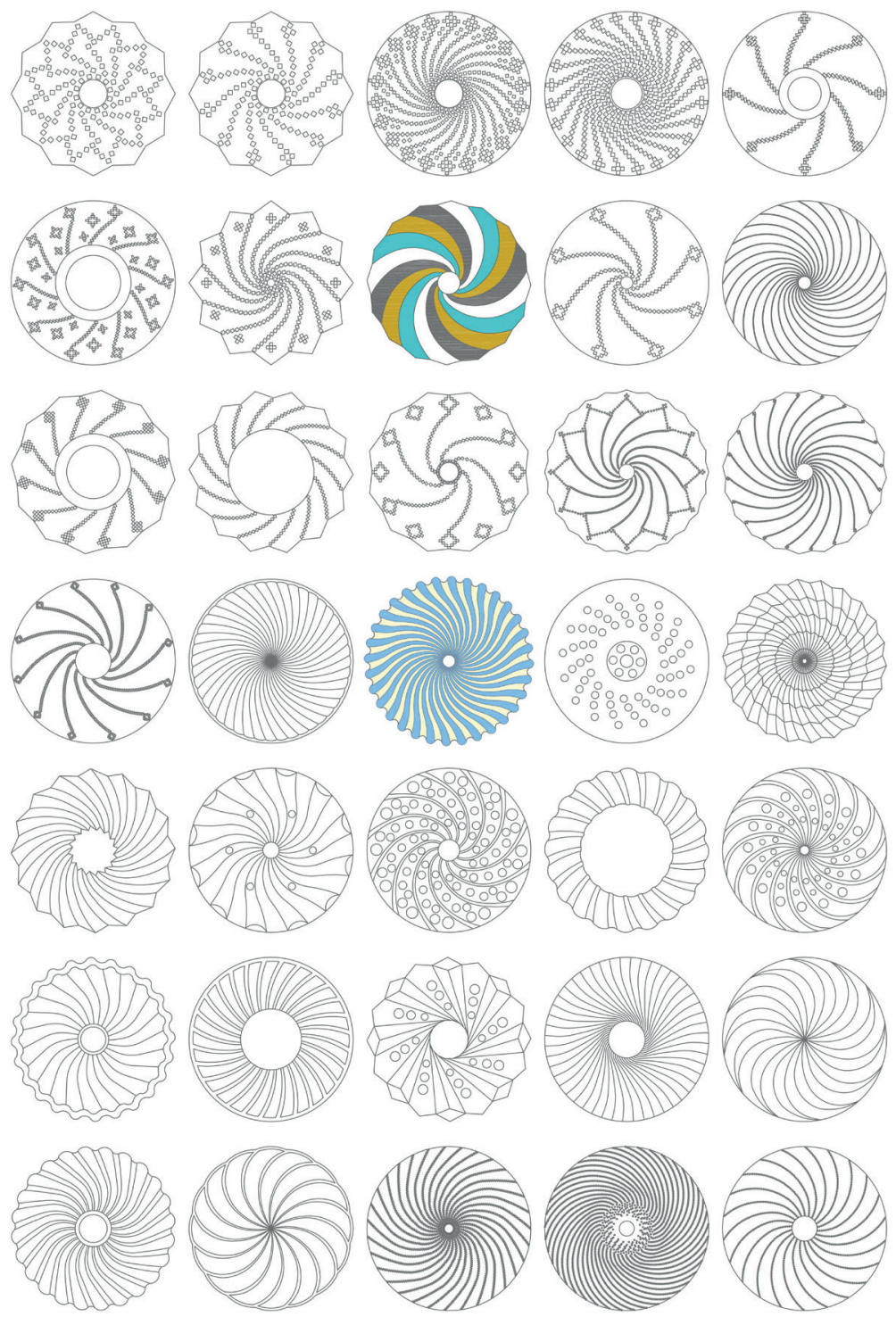

Figure 36: Türk-İslam Mimarisinde Görülen Çarkıfelek Süslemeli Kubbelerin Çizimleri

kubbelerinde yapılan çarkıfelek süslemesinin Türk cihan hâkimiyeti idealini sembolik bir şekilde yansıttığı da ifade edilebilir. Çünkü caminin en önemli birimi olan mihrap önündeki alan diğer birimlerden farklı bir üst örtüye sahiptir. Malatya Ulu Camisi'nde yüksek tromplarla ve kasnakla yükseltilen kubbede böyle bir süslemenin olması tesadüf değildir. Ayrıca Asya renk sembolizminde mavinin göğün rengi olması buradaki gök kubbe sembolizmini de 
pekiştirmektedir ${ }^{80}$. İslam inancında ise Peygamber miracından bahsedilirken, beyaz sedeften yapılmış ve üzerinde besmele yazan dört köşede ayağa oturan büyük bir kubbe anlatılmaktadır. Bu kubbe bütün İslam yapılarının manevi modeli olmuştur ${ }^{81}$. Kubbelerin kendi başına birtakım sembolleri olduğu gibi içerisine yapılan bezemelerle de bu sembollerin daha etkin anlamlara geldiği düşünülebilir.

Kubbe içerisindeki çarkıfelek süslemesi sadece bir bezeme unsuru değil aynı zamanda simgesel anlamı bulunan bir semboldür. İslam'da sanatın amacı her şeyden önce algılanabilen alemlerin ötesindeki gerçek varlığı, göze hitap eden nakışların nakkaşını, mümkün olduğu ölçüde sanatına yansıtmaktır ${ }^{82}$. Bu minvalden baktığımızda çarkıfelek süslemesinin simgesel özelliklerini ayrı ayrı ele almamız gerekmektedir. Çarkıfelek motifi bir merkez etrafında birden çok kıvrımlı kolları ile döngüsel yapıya sahip bir motiftir. Onun merkezi tanrı ile ilişkilendirilen axis mundi (Yer'in ekseni) olarak kabul edilmektedir ${ }^{83}$. Merkezdeki nokta durgun ve gücü üreten kozmik merkez olarak tahayyül edilmektedir ${ }^{84}$. Örneğin Anadolu'da nadir görülse de bilhassa tropik bölgelerde sıklıkla karşılaşılan aşırı uç basınç farklılarından meydana gelen

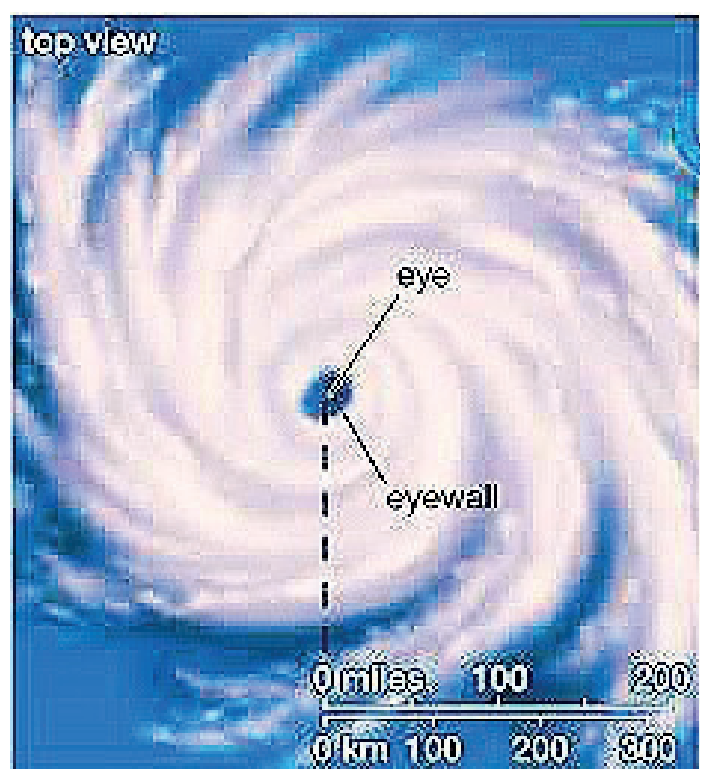

Figure 37: Tropik Hortumun Uzaydan Çarkıfelek Biçiminde Görünüşü (Kaynak: https://www.britannica.com/science/ tropical-cyclone hortumun üstten görünümü çarkıfelek motifi şeklindedir (F.37). Hortumun döngüsel etkisinden çevresindeki nesneleri merkeze doğru çektiği bundan dolayı merkezin (göz) etrafında kıvrımlı kolların oluştuğu görülmektedir. Merkez, gücün ortaya çıktığı etrafa yayıldığı alandır. Belirtmek istediğimiz nokta ise hortum çevresinde şiddetli yıkımlara yol açarken merkezinin ise tezat olarak sakin olması söz konusudur. Bundan dolayı çarkıfeleğin merkezini tüm gücün toplandığı ve buradan çevreye dağıldığı alan olarak düşünebiliriz. Rene Guenon'un çarkıfeleklerde söz konusunun siradan bir hareket olmadığını, aksine hareket etmeyen bir eksen veya bir merkez etrafinda gerçekleşen bir hareketin olduğunu belirtmesi söz konusu formun doğal

80 Semra Ögel, Anadolu Selçuklu Sanatı Üzerine Görüşler, İstanbul, 1986, s. 91

81 Titus Burckhardt, “İslam San'atının Esasları”, Kubbealtı Akademi Mecmuası, C.18, S.1, İstanbul, 1989, s. 57.

82 Turan Koç, İslam Estetiği, İstanbul, 2009, s. 45.

83 Seyyid Hüseyin Nasr, İslam Sanatı ve Maneviyatı, Çev, Ahmet Demirhan, İstanbul, 2017, s. 73.

84 J. C. Cooper, "Wheel", An Illustrated Encyclopaedia of Traditional Symbols, London, 1987, s. 191. 
yapısına açıklık getirmektedir ${ }^{85}$. İslam fillozoflarının çoğu, "feleklerin hiçbir bölünmeyi kabul etmeyen sürekli dairevi hareketi, önceliği olmayan bir harekete bağlı ezeli bir süreklilik" gibi tariflerle ifade etmişlerdir ${ }^{86}$. Taoculuğun maddeye bakışına göre doğa durmaksızın döngü yasasına uygun olarak dönüşmektedir. Onun zıtları, idrakten kaçan tek bir merkez etrafında dönmektedir. Bu dairesel hareketi idrak eden herkes merkezi yani hareketin özünü tanımaktadır ${ }^{87}$. Merkez aynı zamanda kubbenin en yüksek yeri, zirvedir. Bu zirve cennet olarak tahayyül edilmektedir. İbni Bibi İzzeddin Keykavus'un ölümünde çaşnigir Seyfeddin Ayaba'nın Alaeddin Keykubat'a "Kardeşinizin ruhu, bu toprak dünyadan kalkarak feleklerin zirvesine uçtu. Aden cennetlerine giderek Kevser suyuna kavuştu" dediğini belirtmektedir ${ }^{88}$. Kubbenin merkezindeki kolların çıktığı göbek, bu ibareden anlaşılacağı üzere cennetin karşılığı olduğu ifade edilebilir. Kubbenin ortasındaki aydınlık fenerinden gelen parıltı ışı sembolizmi ile ilişkilendirilebilir. Doğu dinlerinde ve iptidai dinlerde yaygın olarak tanrının alemde ışık şeklinde zuhur ettiğine dair inanç yaygındır ${ }^{89}$. Kur'an-1 Kerim'de Nur Suresi'nde "Allah göklerin ve yerin 1şı̆̆ıdır" "90 şeklinde ayetin geçmesi tanrı ile ışık (nur) arasında bir bağlantının olduğunun işaretidir. Tabi bu ayetteki nurun aslında nazari değil mecazi anlamda kullanıldığı belirtilebilir. Lakin İslam süsleme sanatlarında nurla ilgili mum, şamdan, fener, kandil gibi simgeler ile madalyon, rozet, şemse, kurs gibi imgeler İslam tasavvurundaki ışı sembolizminden ortaya çıkmışırı. Bu açıdan baktığımızda kubbenin ortasında yer alan aydınlık fenerinin doğrudan bir ışık kaynağı olduğu görülür. Kubbe ortasındaki madalyonun ise güneşi temsil ettiği düşünülecek olursa yine ışıla doğrudan ilişkili bir motif olduğu görülecektir. Osmanlı döneminde kubbe merkezindeki madalyon içerisinde Nur suresinin 35 . Ayetinin yazılması simgenin yazıya dökülmüşş şeklidiri ${ }^{9}$.

Tasavvufun ana konularından olan evrendeki birlik düşüncesini aktarmak için mutasavvıflar birtakım imgelere ihtiyaç duymuştur ${ }^{22}$. İbn'ül Arabi, her fenomenin bir numeni olduğunu yani tüm görünenin (zahiri) aslında bir deruni (batıni) anlamı bulunduğunu kabul etmekte ${ }^{93}$ ve ariflerin duygularını başkalarına nakledemediklerini ancak onları, mütecessislere benzeri imge, sembol ve remizlerle aktarabildiklerinden bahsetmektedir ${ }^{94}$. Bu sembolizm soyut anlamda İslam şiirinde yer bulduğu gibi somut anlamda İslam süslemesinde kendini göstermektedir. İşte İslam süslemesinde bu simgelerden biri de kuşkusuz çarkıfelek motifidir. Çarkıfelek formlu kubbelerde üst örtünün en yüksek kısmından kolların bir merkezden çıkması (vahdet) İslam'ın tevhid akidesi ile örtüşmektedir. Yaratıc1; aşkın (transandant) bir varlık olarak bütün

85 Rene Guenon, Alemin Hükümdarı Dinlerde Merkez Sembolizmi, Çev. İsmail Taşpınar, İstanbul, 2014, s. 19.

86 İsmail Erdoğan, "Bazı İslam Düşünürlerine Göre Zamanın Kıdemi Meselesi”, Fırat Üniversitesi İlahiyat Fakültesi Dergisi, S.2, Elâzı̆̆, 1997, s. 52-53.

87 Titus Burckhardt, Doğu'da ve Batı'da Kutsal Sanat, Çev. Tahir Uluç, İstanbul, 2017, s. 13-14.

88 İbn-i Bibi, a.g.e., s. 225.

89 T. J. De Boer, "Nur", İA, C.9, İstanbul, 1964, 353.

90 Kuran-1 Kerim 24/35.

91 Semra Ögel, "Osmanlı Camii ve Birlik Kavramı", Osmanlı Toplumunda Tasavvuf ve Sufiler, Ankara, 2014, 513.

92 Semra Ögel, a.g.e., 1986, s. 100.

93 Seyyid Hüseyin Nasr, Three Muslim Sages, New York, 1969, s. 103.

94 Reynold A. Nicholson, İslam Sufileri, Çev. Mehmet Dağ, vd., İstanbul, 1978, s. 88. 
tabiatın ve varlıkların üstündedir. Her şey onun eseridir. Merkezden dalgalar halinde çıkan kollar (kesret) ise ihsan, cömertlik, bolluk, adalet ve denge gibi aslında güzelliğin temel özelliklerini yansıtırlar. Vahdet-kesret ilişkisi içerisinde baktığımızda "Kesret vahdetin aynası gibidir. Bakmasını bilen kişi aynada bir tek yüz görür. (Yani Hakk'ı görür) "'95 şeklindeki Yunus Emre'nin sözleri, buradaki sembolizmi bir nebze olsun açıklamaktadır.

Kubbelerin göbeğinden başlayarak eteklerine doğru açılan çarkıfelek süslemesi sürekli devinim halinde olan göğü sembolize etmektedir. Kâinatta makro ölçekteki yıldız sistemlerinden tutun da mikro ölçekteki atom parçalarına kadar her bir yapı taşı döngüsel bir hareket halinde olmuştur. Bilim felsefesinde evrende bir varlığın varlığını koruyabilmesi için sürekli hareket etmesi gerektiği belirtilir. İlginçtir ki güneş sisteminin de içerisinde bulunduğu samanyolu galaksisinin şekli aynı kubbelerde yapılan çarkıfelek formu şeklindedir (F.38). Merkezinde bulunduğu düşünülen kara delik, çevresinde kıvrımlı kollar meydana getirmiştir. Tabi bunu o dönemdeki insanlar teleskop gibi bir araçları olmadığı için bilmiyorlardı. Ancak güneş sisteminin dönmesini tasavvur ederek böyle bir çark düşünmüş olmalılar. Ki Eski Türk inancinda Tengri’yi güneş, güneşi daire sembolize etmekteydi. Evrenin hareketi ise çarkıfelek motifi ile ifade edilmekteydi. Yusuf Has Hacib'in eseri Kutadgu Bilig'de “(Tanrt) Cihanı yarattı, durmadan dönmektedir. Onunla beraber bütün seyyareler sürekli hareket etmektedir" "96 şeklinde belirttiği evren

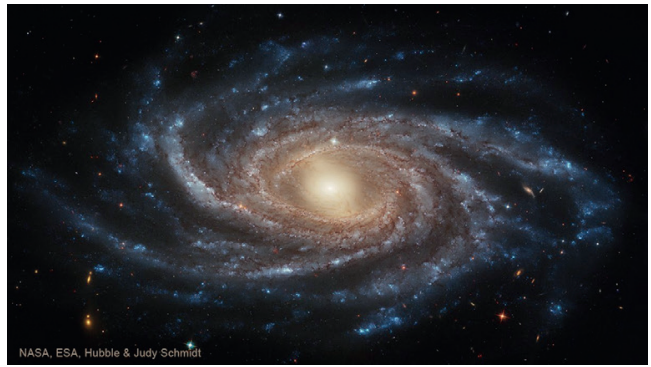

Figure 38: Samanyolu Galaksisinin Çarkıfelek Biçimindeki Görünüşü (Kaynak: https://www.nasa.gov/image-feature/ goddard/2020/hubble-views-a-galaxyburning-bright) tasavvuru durağan olmayan devinim halindeki kainat düşüncelerini ortaya koymaktadır. Aslında gündüzün geceye dönmesi, yazın kışa dönmesi, doğadaki su, azot, karbon ve oksijen döngüsü gibi sonsuz deveran sanata yansımıştır.

Ayrıca bu döngüsellik sonsuzluk düşüncesi ile de ifade edilebilir. Allah'ın kudreti, ilmi, merhameti, azameti gibi tenzihi sıfatları hep sonsuz olarak açıklanmaktadır. Bununla birlikte sembol Allah'ın yaratıcı gücünün, Hay'dan gelen her şeyin yine Hu'ya dönüşünün ve evrenin hareketinin sembolü olarak yorumlanmaktadır ${ }^{97}$. Çarkıfelek motifinin mezar taşlarında ölümsüzleştirme amacı ile kullanıldığı belirtilmektedir ${ }^{98}$. Özellikle türbelerde kubbenin çarkıfelek bezemeli yapılması, mezar taşları üzerinde kullanılan çarkıfelek sembolü ile aynı amaçtadır. Diğer mimari eserlerin üst

95 Sevtap Yazar, "Yunus Emre ve Tasavvuf”, http://web.deu.edu.tr/ilyas/edebiyat/yunusvetasavvuf.htm\#_edn1 Erişim Tarihi: 20.12.2020

96 Semra Ögel, a.g.e., 1986, s. 99’den Yusuf Has Hacib, Kutadgu Bilig Tıpkıbasım I Viyana Nüshası, İstanbul, 1942, s. 38.

97 Şaman Doğan, a.g.e., s. 247.

98 Beyhan Karamağaralı, Ahlat Mezar Taşları, Ankara, 1992, s. 36. 
örtüsünde çarkıfeleğin kullanılması ise yapının sonsuza kadar ayakta kalması amacı ile geleceğe aktarılması için bir tılsım olarak da düşünülebilirr9 ${ }^{99}$ Çarkıfeleklerin dönüş yönlerinde de mutlaka bir takım sembolizm mevcuttur. Eski Türklerde Gök kubbenin ve gök çarkının hareket halinde olduğu düşüncesi vardır. Güneş ve ayın birbirinin zıddı olarak tahayyül edildiği belirtilmektedir. Yani güneş doğudan yükseldiğinde ayın yerin altındaki suya battığ 1 sanılmaktayd1 ${ }^{100}$. Saat yönünde hareketi veya tersi yöndeki hareketin yapılmasında böyle bir amaç güdülmüş olabilir. Bilhassa hamamların su ile olan ilişkisinden ötürü kubbelerinde aynı yönde çarkıfeleklerin kullanılmasını istisnalar olsa da buna örnek olarak gösterebiliriz. Benzer şekilde Hinduizm'de svastika motifinin saat yönünde dönüşü Güneş gezegeni ile refah ve aydınlık gibi olumlu yönde düşünülen kavramları; tersi yönde dönmesi ise Ay gezegeni ile karanlık gibi olumsuz yönde tasavvur edilen kavramları temsil etmektedir ${ }^{101}$.

Çarkıfelek süslemeli kubbelerle Avrupa mimarisinde çok fazla örnek tespit edilememiştir. Kubbe karnında Prag İspanyol Sinagogu'nda görülmektedir (F.39). Bu sinagogun süslemesinde İslam sanatı etkileri söz konusudur. Çarkıfelek süslemeli kubbe geleneğini Türk-İslam mimarisinden almış olabilirler. Kubbenin sırtında yapılmış çarkıfelek formuyla ise Moskova'daki Aziz Basil Katedralinde karşılaşmaktayız (F.40). Katedralin Üç Patrik Şapeli'nin ve Mesih'in Kudüs'e Giriş Şapeli’nin soğanvari formundaki kubbesi çarkıfelek bezemelidir. Burada büyük kubbelerin yanı sıra küçük kubbelerde de çarkıfelek bezeme yapılmıştır. Çarkıfelek süslemelerin Türk-İslam Sanatından alınıp alınmadığı bilinmese de soğanvari formlu kubbelerin Hint mimarisinden alındığına dair iddialar mevcuttur.

99 Ahmet Çaycı, İslam Mimarisinde Anlam ve Sembol, Konya, 2017, 235.

100 Esin, a.g.e., s. 42.

101 Miranda Bruce Mitford, The Illustrated Book of Signs \& Symbols, New York, 1996, s. 21. 


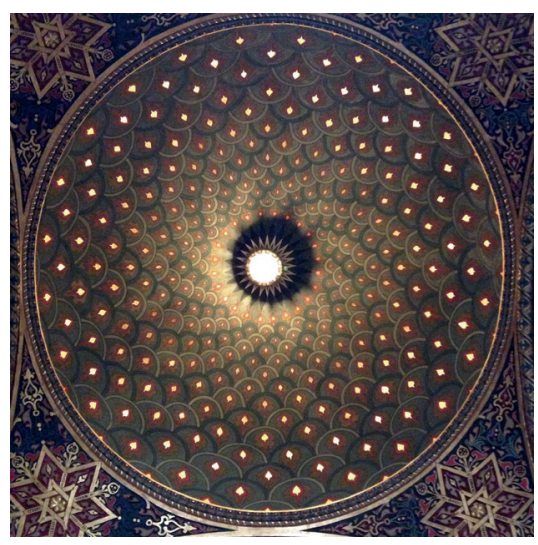

Figure 39: Çekya Prag İspanyol Sinagogu Kubbe Süslemesi (Kaynak: https:// flirtingwithcreativity.files. wordpress.com/2015/06/ img_3737.jpg)

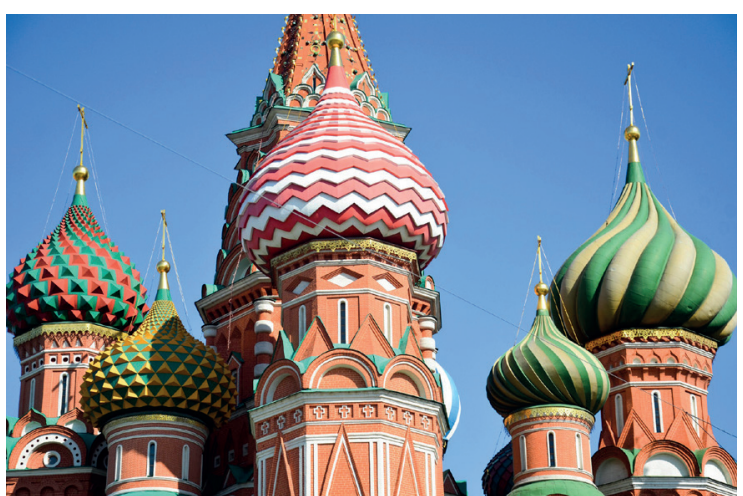

Figure 40: Rusya Moskova St. Basil's Cathedral (Kaynak: https://www.mentalfloss.com/ article/76266/12-facts-about-saint-basils-cathedral)

Çarkıfelek süslemeli kubbeler sadece geçmiş yapılarda kullanılmamış kültür mirasımızdaki bu süsleme günümüze yakın dönemde yapılan camilerde de kullanım bulmuştur. İstanbul Şakirin Camisi (2009) (F.41), Ankara Ahmet Hamdi Akseki Camisi (2013) (F.42), Moskova Ulu Camisi (2015) (F.43) ve İstanbul Marmara Üniversitesi İlahiyat Fakültesi Camisi (2015) (F.44) kubbelerinde çarkıfelek süslemesinin farklı örnekleri ile karşılaşmaktayız. Özellikle İstanbul Marmara Üniversitesi İlahiyat Fakültesi Camisi kubbesinde farklı ve özel bir denemeye gidilmiştir. Kubbedeki çarkıfelek süslemesinin kolları camdan yapıldığı için hem merkezdeki aydınlık fenerinden hem de kollardan caminin ışık alması sağlanmıştır. Ayrıca çarkıfelek süslemesi kubbenin hem içinden hem de dışından algılanabilmektedir. Bu açıdan baktığımızda kubbenin karnında ve sırtında birlikte kullanılan tek örnek olduğunu söyleyebiliriz. 


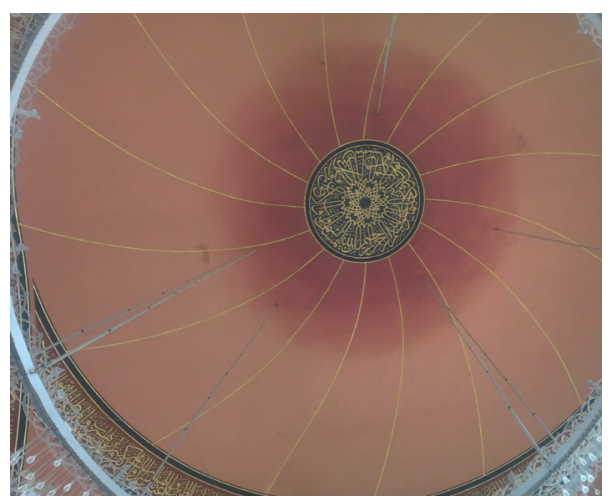

Figure 41: İstanbul Şakirin Camisi Kubbe Süslemesi (Alper Altın, 2019)

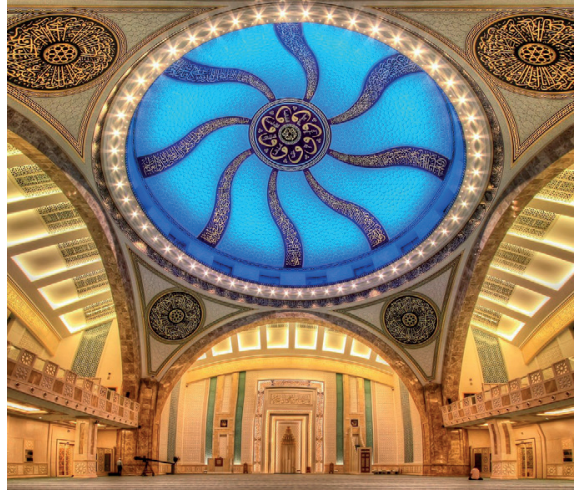

Figure 42: Ankara Ahmet Hamdi Akseki Camisi Kubbe Süslemesi (Kaynak: https://www. flickr.com/photos/10412707@ N05/14643817375)

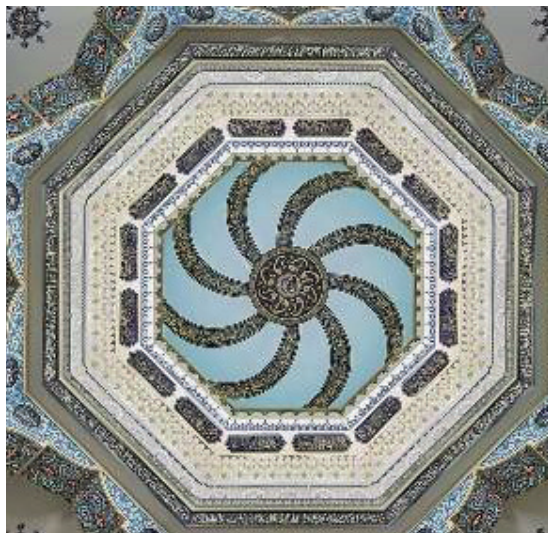

Figure 43: Rusya Moskova Ulu Camisi Kubbe Süslemesi (Kaynak: https://www.kuveytturkozel.com. tr/hizmetlerimiz/kultur-sanathizmetleri/sanatlar/kubbelerinsanati-kalemisi.7.aspx)

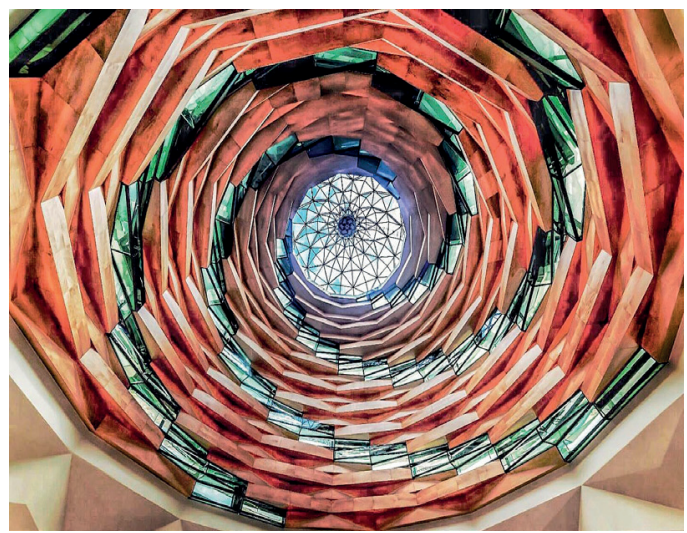

Figure 44: İstanbul Marmara İlahiyat Fakültesi Camisi Kubbesi (Kaynak: https:// www.perfopan.com/perfopan_ahsap_akustik panel_referanslar_tek_marmara_ilahiyat_ camii.html)

Hakem Değerlendirmesi: Dış bağımsız.

Çıkar Çatışması: Yazar çıkar çatışması bildirmemiştir.

Finansal Destek: Yazar bu çalışma için finansal destek almadığını beyan etmiştir.

Peer-review: Externally peer-reviewed.

Conflict of Interest: The author has no conflict of interest to declare.

Grant Support: The author declared that this study has received no financial support. 


\section{Kaynakça/References}

Adıbelli, Ramazan, Mircea Eliade ve Din Mircea Eliade'nin Din Bilimi Çalışmalarının Metodolojik Açısından Değerlendirilmesi, İstanbul, 2011.

Akçıl, N. Çiçek, "Rüstem Paşa Kervansarayı”, DİA, C.35, İstanbul, 2008, s. 290-291.

Altın, Alper, "Türk-İslam Sanatı Geometrik Süslemesinde Ali İsminin Üç Kollu Çarka Uyarlanması”, Akademik Hassasiyetler, Sanat Tarihi Özel Sayıs1, Ankara, 2019, s. 23-54.

Altın, Alper, Anadolu Selçuklu Mimarisindeki Geometrik Süslemelerde Restorasyon Hataları, Konya, 2020.

Arık, M. Oluş, "Malatya Ulu Camiinin Asli Planı ve Tarihi Hakkında", Vakıflar Dergisi, S.8, Ankara, 1969, s. $141-145$.

Arslan, Muhammet, Anadolu'da Selçuklu Çağı Cami ve Mescit Mimarisi (Plan-Mimari-Süsleme), Atatürk Üniversitesi Sosyal Bilimler Enstitüsü Yayınlanmamış Doktora Tezi, Erzurum, 2016.

Ayverdi, Ekrem Hakk1, Avrupa'da Osmanlı Mimari Eserleri, C.IV, İstanbul, 2000.

Ayverdi, Ekrem Hakk1, Osmanlı Mimarisinde Çelebi ve II. Sultan Murad Devri 806-855 (1403-1451), İstanbul, 1989.

Beheshti, Oksana, Travel Guide to Esfahan, Kashan More, Tahran, 2003.

Behrens-Abouseif, Doris, Islamic Architecture in Cairo an Introduction, Leiden, 1998.

Bruce Mitford, Miranda, The Illustrated Book of Signs \& Symbols, New York, 1996.

Burckhardt, Titus, “İslam San'atının Esasları”, Kubbealtı Akademi Mecmuası, C.18, S.1, İstanbul, 1989, s. 46-63.

Burckhardt, Titus, Doğu'da ve Batı'da Kutsal Sanat, Çev. Tahir Uluç, İstanbul, 2017.

Cipriani, Barbara, Development of Construction Techniques in the Mamluk Domes of Cairo, Venezia Üniversitesi Mimarlık Enstitüsü Yayınlanmamış Yüksek Lisans Tezi, Venedik, 2005.

Cooper, J. C., "Triquetra/Triskele/Fylfot”, An Illustrated Encyclopaedia of Traditional Symbols, London, 1987, s. 181-182.

Cooper, J. C., "Wheel”, An Illustrated Encyclopaedia of Traditional Symbols, London, 1987, s. 191.

Çaycı, Ahmet, “Zaman ve Sanat Bağlamında Çark-1 Felek Motifi”, Uluslararası İslam Medeniyetinde Zaman Seтроzуити Bildiriler Kitabı, C.II, İstanbul, 2016, s. 299-305.

Çaycı, Ahmet, Anadolu Selçuklu Sanatında Gezegen ve Burç Tasvirleri, Konya, 2019.

Çayc1, Ahmet, İslam Mimarisinde Anlam ve Sembol, Konya, 2017.

Çetin, Yusuf, "Türk-İslam Bezeme Sanatında Gamalı Haç (Svastika) ile Çarkıfelek Motiflerinin Köken ve İkonografik Anlamları Üzerine Bir Değerlendirme”, Social Sciences Studies Journal, C.3/8, İstanbul, 2017, s. 353-365.

Daş, Ertan, "Mezar Taşlarında Svastika ve Çarkıfelek Sembollerinin Kökeni ve Anlamı”, 1. Uluslararası Türk-İslam Mezar Taşları Kongresi Bildiriler Kitabı, Aydın, 2018, s. 199-206.

De Boer, T. J., "Nur”, İA, C.9, İstanbul, 1964, 352-355.

Demiriz, Yıldız, İslam Sanatında Geometrik Süsleme, İstanbul, 2004.

Diyarbekirli, Nejat, Hun Sanat, İstanbul, 1972.

Duman, Mehmet Akif, “Şans Tanrıçası Fortuna’nın Tekerleği ile "Kader” İnancının Bir Unsuru Olarak “Çark-1 Felek”, Özne Felsefe ve Bilim Yazıları 21. Kitap - Felsefi Bir Sorun Olarak İnanma, Konya, 2015, s. 163-192.

Eberhard, Wolfram, Çin Simgeleri Sözlüğü, Çev. Aykut Kazancıgil-Ayşe Bereket, İstanbul, 2000. 
Ehteshami, Azin-Soltaninejad, Mehdi, "An Introduction to Architecture of Nasir Al-Mulk Mosque", World Journal of Engineering and Technology, S.7, Bhandara, 2019, s. 652-675.

Eliade, Mircea, Dinler Tarihine Giriş, Çev. Lale Arslan, İstanbul, 2003.

Eravşar, Osman- Karpuz, Haşim Büyük Selçuklu Mirası Mimari, C.1, İstanbul, 2013.

Eravşar, Osman- Karpuz, Haşim Büyük Selçuklu Mirası Mimari, C.2, İstanbul, 2013.

Erdoğan, İsmail, “Bazı İslam Düşünürlerine Göre Zamanın Kıdemi Meselesi”, Fırat Üniversitesi İlahiyat Fakültesi Dergisi, S.2, Elâzı̆̆, 1997, s. 51-61.

Erken, Sabih, "Edirne Hamamları”, Vakıflar Dergisi, S.10, Ankara, 2006, s. 403-419.

Ertuğrul, Selda, “Îsâ Bey Camii”, DIA, C.22, İstanbul, 2000, s. 476-478.

Esin, Emel, ““'Kün-Ay” (Ay-Yıldız Motifinin Proto-Türk Devirden Hakanlılara Kadar İkonografisi)”, VII. Türk Tarih Kongresi, C.I, Ankara, 1972, s. 313-359.

Esin, Emel, Türk Kozmolojisine Giriş, İstanbul, 2001.

Evliya Çelebi, Evliya Çelebi Seyahatnamesi, C.IX, İstanbul, 2005.

Evliya Çelebi, Günümüz Türkçesi ile Evliya Çelebi Seyahatnamesi, Haz. Seyit Ali Kahraman, C.10/1, İstanbul, 2011.

Eyice, Semavi, "Bayezıt II Cami ve Külliyesi”, DİA, C.6, İstanbul, 1992, s. 42-45.

Eyice, Semavi, "Bayezid Paşa Camii”, DİA, C.5, İstanbul, 1992, s. 243-244.

Eyice, Semavi, “İsmail Bey Hamamı”, DİA, C.23, İstanbul, 2001, s. 86-87.

Feridüddin Attar, Esrarname, Çev. Mehmet Kanar, 2013.

Gabriel, Albert, Monuments Turcs D'anatolie, C.II, Paris, 1934.

Gabriel, Albert, Voyages Archeologiques Dans la Turquie Orientale, Paris, 1940.

Guenon, Rene, Alemin Hükümdarı Dinlerde Merkez Sembolizmi, Çev. İsmail Taşpınar, İstanbul, 2014.

Gümüştekin, Nuray, “Anadolu ve Diğer Kültürlerde İşaret ve Simgelerde Anlam”, Balıkesir Üniversitesi Sosyal Bilimler Dergisi, C.14, S.11, Balıkesir, 2011, s. 103-117.

Gündüz, Filiz, “Mahmud Paşa Külliyesi”, DİA, C.27, Ankara, 2003, s. 380-381.

Hasol, Doğan, “Kubbe”, Ansiklopedik Mimarlık Sözlüğü, İstanbul, 1998, s. 280.

Hutt, Anthony-Harrow, Leonard, Islamic Architecture Iran, C.2, Ipswich, 1978.

İbn-i Bibi, El Evamirü'l-Ala 'iye Fi'l-Umuri'l-Ala 'iye (Selçuk Name), C.I, Çev. Mürsel Öztürk, Ankara, 1996.

Jaffe, Aniela, “Görsel Sanatlarda Sembol”, İnsan ve Sembolleri, Çev. Ali Nahit Babaoğlu, İstanbul, 2019, s. 230-271.

Kanar, Mehmet, Osmanlı Türkçesi Sözlüğü, İstanbul, 2009.

Karamağaralı, Beyhan, "İçiçe Daire Motiflerinin Mahiyeti Hakkında", Sanat Tarihinde İkonografik Araştırmalar Güner İnal'a Armağan, Ankara, 1993, s. 249-270.

Karamağaralı, Beyhan, Ahlat Mezar Taşları, Ankara, 1992.

Kaşgarlı Mahmud, Dîvânu Lugâti 't-Türk, C.II, Çev. Besim Atalay, Ankara, 1985.

Keklik, Can, Bursa, Erken Dönem Osmanlı Hamamları, Marmara Üniversitesi Sosyal Bilimler Enstitüsü Yayınlanmamış Yüksek Lisans Tezi, İstanbul, 1996.

Keyani, Muhammed Yusuf, İslam Dönemi İran Mimarisi, Ankara, 2018.

Koç, Turan, İslam Estetiği, İstanbul, 2009.

Kuban, Doğan, "Edirne'de Bazı İkinci Murat Çağı Hamamları Mukarnas Bezemeleri Üzerine Notlar", Ord. Prof. İsmail Hakkı Uzunçarşıll 'ya Armağan, Ankara, 1976, s. 447-460. 
Kuban, Doğan, “Kubbe”, Mimarlık Kavramlarl, İstanbul, 2002, s. 45-46,

Kula Say, Seda, Erken Dönem Osmanlı Hamamlarında Ĕ̆risel Örtüye Geçiş Sistemleri, İstanbul Teknik Üniversitesi Fen Bilimleri Enstitüsü Yayınlanmamış Yüksek Lisans Tezi, İstanbul, 2007.

Macleod, Mayhew, Decouverte Ouzbekistan Samarcande, Boukhara, Khiva, Cenevre, 2019.

Nasr, Seyyid Hüseyin, İslam Sanatı ve Maneviyatı, Çev, Ahmet Demirhan, İstanbul, 2017.

Nasr, Seyyid Hüseyin, Three Muslim Sages, New York, 1969.

Nicholson, Reynold A., Íslam Sufileri, Çev. Mehmet Dağ, vd., İstanbul, 1978.

Nizamüddin Şami, Zafername, Çev. Necati Lugal, Ankara, 1987.

Ögel, Bahaeddin, Türk Mitolojisi, C.II, Ankara, 1995.

Ögel, Semra, “Osmanlı Camii ve Birlik Kavramı”, Osmanlı Toplumunda Tasavvuf ve Sufiler, Ankara, 2014, 509-513.

Ögel, Semra, Anadolu Selçuklu Sanatı Üzerine Görüşler, İstanbul, 1986.

Ögel, Semra, Anadolu'nun Selçuklu Çehresi, İstanbul, 1994.

Özer, Mustafa- Dündar, Mesut, "Edirne Sarayı Kum Kasrı Hamamı ve Aşçılar Hamamı”, Akdeniz Sanat Dergisi, S.19, Antalya, 2019, s. 571-584.

Peker, Ali Uzay, “Türklerin Evrensel Hükümdarlığının İran’da Sanat ve Mimariye Getirdiği Açılımlar”, Denge Dergisi, S.1, Ankara, 2016, s. 39-64.

Rawlinson, George, The Seventh Great Oriental Monarchy or the Geography, History, and Antiquities of the Sassanian or New Persian Empire, C.II, New York, 1882.

Schroeder, Eric, “The Seljuk Period”, A Survey of Persian Art from Prehistoric Times to Present, C.3, New York, 1967, s. 981-1045.

Soyaker, Sevgi, “Bergama’da Türk Hamamları”, Bergama Belleten, S.2, İzmir, 1992, s. 27-34.

Sözen, Metin, Anadolu Medreseleri Selçuklu ve Beylikler Devri, İstanbul, 1970.

Sutton, Daud, Islamic Design a Genius for Geometry, Bloomsbury, 2007.

Şaman Doğan, Nermin, “Oklu Çakır/Oklu Çark/Gök Çı̆̆grısı: Selçuklu Süslemesinde Bir Motif”, I. Uluslararası Selçuklu Kültür ve Medeniyeti Kongresi Bildiriler, C.I, Konya, 2001, s. 243-249.

Şehitoğlu, Elif, Bursa Hamamları, İstanbul, 2008.

Şimşir, Zekeriya-Yavuzyılmaz, Ahmet, "Yeni Bulunan Bir Selçuklu Kitabesi: İç Karaarslan Mescidi Kitabesi”, Selçuk Üniversitesi Sosyal Bilimler Enstitüsü Dergisi, Prof. Dr. Fuat Sezgin Özel Sayıs1, Konya 2019, s. 91-103.

Tuncer, Orhan Cezmi, Anadolu Kümbetleri 2 Beylikler ve Osmanlı Dönemi, Ankara, 1991.

Williams, Caroline, Islamic Monuments in Cairo the Practical Guide, Cairo, 2008.

Yazar, Sevtap, "Yunus Emre ve Tasavvuf”, http://web.deu.edu.tr/ilyas/edebiyat/yunusvetasavvuf.htm\#_edn1 Erişim Tarihi: 20.12.2020

Yusuf Has Hacib, Kutadgu Bilig Tıpkıbasım I Viyana Nüshası, İstanbul, 1942.

https://en.wikipedia.org/wiki/Sa\%27d_al-Saltaneh_Caravanserai Erişim Tarihi: 25.11.2020

https://archnet.org/sites/18620 Erişim Tarihi: 01.12.2020

https://www.islamichistoryandtravel.com/sultan-amir-ahmad-hammam-bath-house-kashan/ Erişim Tarihi:

16.11.2020 